Portland State University

PDXScholar

\title{
The Petrology and Stratigraphy of the Portland Hills Silt
}

Rodney Thomas Lentz

Portland State University

Follow this and additional works at: https://pdxscholar.library.pdx.edu/open_access_etds

Part of the Geology Commons, and the Sedimentology Commons Let us know how access to this document benefits you.

Recommended Citation

Lentz, Rodney Thomas, "The Petrology and Stratigraphy of the Portland Hills Silt" (1977). Dissertations and Theses. Paper 2468.

https://doi.org/10.15760/etd.2452

This Thesis is brought to you for free and open access. It has been accepted for inclusion in Dissertations and Theses by an authorized administrator of PDXScholar. Please contact us if we can make this document more accessible: pdxscholar@pdx.edu. 
AN ABSTRACT OF THE THESIS OF Rodney Thomas Lentz for the Master of Science in Geology presented May 26, 1977.

Title: The Petrology and Stratigraphy of the Portland Hills Silt. APPROVED BY MEMBERS OF THE THESIS COMMITTEE:

\author{
Robert 0. Van Atta, Chalrman
}

Paul E. Hawond

Richard E. Thoms

Detalis concerning the 1ithology and mode of origin of the Portland Hills Silt have long been a subject of controversy. The silt has been variously described as wind deposited, water-laid, or a combination of the two.

The present investigation carefully examines the lithology and stratigraphy of the Portland Hills Silt on the basis of field observations and detalled lateral and vertical sampling. Over 100 uniform and varible depth samples were obtained from outcrops and 4.7-13.4 m (15-45 ft) deep sections located in and around the Tualatin Mountain region, Oregon and. Washington.

The Portland Hills Silt is uniform both in texture and composition. 
The average grain size distribution indicates 77 percent silt-, 19 percent clay- and 5 percent sand-sized particles, very poor sorting and a fine skewed grain size distribution. The median grain size fines westward from about $.041 \mathrm{~mm}$ near the Portland basin, to $.022 \mathrm{~mm}$ on the west slope of the Tualatin Mountalns.

Quartz and feldspar constitute 35 and 36 percent respectively, of the total mineral composition. Clay minerals (15\%), coarse-grained micas (6\%), rock detritus and volcanic glass (5\%) and heavy minerals (3\%) make up lesser quantities. The heavy mineral sulte is composed of hornblende (41\%), opaques (17\%), epidote (15\%), auglte (10\%), a varlety of metamorphic species and very minor hypersthene.

The Portland Hills Silt is overlain by the Willamette Silt and underlain or possibly interstratified with the Boring Lava. Carbon 14 age dating and paleomagnetic data suggest deposition between approximately 34,400 and 700,000 (?) years B.P. The silt's thickness decreases from about $37 \mathrm{~m}(120 \mathrm{ft})$ on the east side of the Tualatin Mountains to near zero in the Chehalem Mountains, some $27 \mathrm{~km}$ (18 mi) to the west.

The deposit is essentially massive. However, deeper exposures may reveal up to four $2-8.5 \mathrm{~m}$ thick sllt units, which are delineated by darker paleosols. The units are tentatively correlated with major glacial deposits of western Washington; the Orting and Stuck Drifts and the Upper and Lower Tills of the Salmon Springs Drift. The silt is also correlated, in part, with the Palouse Soll of eastern Washington.

The distributional, textural and morphological character of the Portland Hills Silt strongly Indicates a loesslal origin from the sediments of the Columbia River floodplain. 
RODNEY THOMAS LENTZ

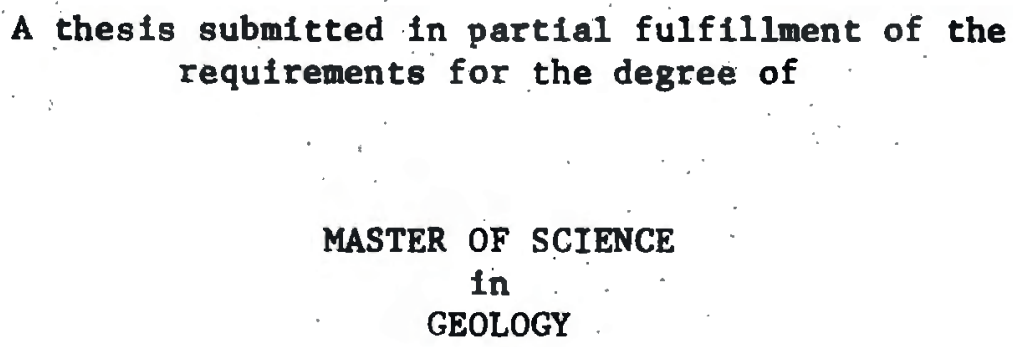

Portland State University

1977 
TO THE OFFICE OF GRADUATE STUDIES AND RESEARCH:

The members of the Committee approve the thesis of

Rodney Thomas Lentz presented May 26, 1977.

Robert 0. Van Atta, Chairman

Paul E. Hammond

Richard E. Thoms

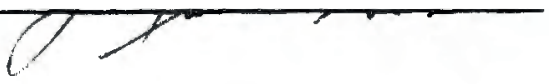

APPROVED:

Mar in H. Beeson, Head, Department of Earth Sciences

Staniey E. Much, Dean or liraduate Studies and Research 


\section{ACKNOWLEDGMENTS}

The writer is indebted to his advisor Dr. Robert 0. Van Atta for suggesting the profect, for his ald in clay mineral $x$-ray diffraction and for his many helpful suggestions and comments in every phase of the study. The writer also thanks Drs. R. E. Thoms, P. E. Hammond and G. T. Benson. Their editorial comments and suggestions were very much appreclated.

Special acknowledgment and thanks are extended to $\mathrm{Dr}$. J. L. Glenn and Dr. R. W. Lounsbury for helpful discussion and correspondence therew1th. I thank also, Don Chitwood, for his assistance in the use of the scanning electron microscope; Dan Leach, for his suggestions and aid with the Faxitron x-ray machine and Jim Anderson, for his help with the computor program which calculates textural statistics.

The writer expresses particular thanks to Gene Plerson, without whose patience and technical know-how much of the laboratory work would st11l be undone. Thanks also to $\mathrm{B} 11 \mathrm{l}$ Avolio and $\mathrm{CH}_{2} \mathrm{M} H 111$ for providing a sample of the Troutdale Formation from beneath the TualatIn. Valley.

Finally, I thank my wife Lynn, for her patience and good natured understanding, and for putting up with muddy boots, muddy samples and a muddy husband for the duration. 
TABLE OF CONTENTS

PAGE

ACKNOWLEDGMENTS ........................ 111

LIST $O F$ TABLES . . . . . . . . . . . . . . . . . . . . v1 v

LIST OF FIGURES . . . . . . . . . . . . . . . . . . vi11

I INTRODUCTION . . . . . . . . . . . . . . . . 1

LOCATION AND DESCRIPTION OF THE STUDY AREA . . . . . . 4

GEOLOGIC SETTING .................. 7

PREVIOUS WORK . . . . . . . . . . . . . . 12

FIELD METHODS AND SAMPLING PROCEDURES . . . . . . . . . 22

II LITHOLOGY .................... 25

STRUCTURE ..................... 25

Laboratory Procedures ............. 25

Primary Structures . . . . . . . . . . . 26

Secondary Structures............. 33

TEXTURE .......................... 42

Granulometry ................. . . 42

Laboratory procedures ............. 44

General characteristics ............ 45

Outsized clasts................ 49

Fabric.................. 52

Laboratory procedures ............ 52

Fabric character and mica orientation . . . . . . 53

Particle Morphology . . . . . . . . . . . 56

COMPOSITION .......................... 60

Laboratory Procedures . . . . . . . . . . 60

Mineral Composition ................ 61

Light minerals ................ 61

Heavy minerals ................ 64

Clay minerals.............. . 70

Total mineral composition.......... 72

Fossil Components .. . . . . . . . . . . 74 
CLASSIFICATION . . . . . . . . . . . . 74

III STRATIGRAPHY . . . . . . . . . . . . . . 77

REGIONAL STRATIGRAPHY .............. 78

Columbia River Basalt . . . . . . . . . 81

Helvetia .................... 81

Sandy River Mudstone and Troutdale Formations . . . . 82

Boring Lava... . . . . . . . . . . . 83

Willamette Silt............ 86

STRATIGRAPHY OF THE PORTLAND HILLS SILT . . . . . . 91

Distribution and Thickness . . . . . . . . . . 91

Tualatin Mountains . . . . . . . . . . . 91

Outlying reglons ..... . . . . . . . . . 93

Vertical and Areal Variation . . . . . . . 95

Textural variation ............. 95

Compositional variation . . . . . . . . . 98

Paleosols . . . . . . . . . . . ..... 101

Character and recognition . . . . . . . ... 101

Morphological variation . . . . . . . . 102

IV PETROGRAPHIC COMPARISON OF EQUIVALENT AND SIMILAR SEDIMENTS 103

EQUIVALENT SILTS . . . . . . . . . . . . 103

SIMILAR DEPOSITS . . . . . . . . . . 105

Local ................. 105

Reglonal .................... 107

Loess Deposits. . . . . . . . . . . . . 109

v SUMMARY AND CONCLUSIONS

NATURE OF THE DEPOSIT . . . . . . . . . . . . 113

ORIGIN AND AGE . . . . . . . . . . . . . . . 115

Source .................... 115

Mode of Deposition .............. 115

Age ........................ 118

CORRELATION . . . . . . . . . . . . . 119

BIBLIOGRAPHY . . . . . . . . . . . . . . . . 123

APPENDICES . . . . . . . . . . . . . . . . . 130 
LIST OF TABLES

TABLE

PAGE

1 Previous Descriptions of the Portland Hills Silt . . . .

2 Mean Error for Cumulative Percent Values . . . . . . .

3 Textural Data from 21 Widespread Samples taken at Uniform Depth, from Unweathered Portland Hills Silt .......................

4 Average Texture of 67 Widespread Uniform Depth Portland Hills Silt Samples ........... 50

5 Light Minerals in 5 Widespread, Uniform Depth Portland Hills Silt Samples from the Tualatin Mountains

6 Average Percent and Grain Morphology of Light Minerals in 11 Portland Hills Silt Samples .........

7 .Heavy Minerals in 17 Widespread, Uniform Depth Portland Hills Silt Samples from the Tualatin Mountains

8 Average Percent and Grain Morphology of Heavy Minerals in 17 Portland Hills Silt Samples . . . . . . .

9 X-ray Diffraction Data for three Portland Hills Silt Samples. Relative Intensities are Shown in Parentheses . . . . . . . . . . . . . .

10 Total Mineral Composition of the Portland Hills Silt..

11 Comparison of Heavy Minerals in DAH76-1 to Those in Portland Hills Silt and Willamette Silt .....

12 Light and Heavy Minerals in 5 Variable Depth Portland Hills Silt Samples from Section DAH76-6 . . . 100

13 Petrographic Comparison of Equivalent Portland Hills Silt Sediments from the Outlying Portland-Tualatin Valley Region .................

14 Summary of Texture and Heavy Minerals in Similar Tualatin Mountain Deposits... . . . . . . . . 
15 Near Surface Character and Distingulshing Features In Similar Tualatin Mountain Deposits . . . . . 108

16 Comparison of Heavy Mineral Percentages In Simllar Reglonal Sediments............... 110

17 Granulametric Statistics for 20 Portland H11ls Samples from W1despread Tualatin Mountain S1tes . . 131

18 Sand, S11t and Clay Percentages In Portland H11ls S11t, Willamette S1lt, Helvetia and Tualatin Valley Troutdale Equivalent Samples . . . . . . . . . . .

19 Heavy Minerals In Tualatin Valley Troutdale Equivalent, Willamette S1lt and Helvetia Samples .......

PLATE 1 Surficial Geology of the Tualatin Valley Region, 


\section{LIST OF FIGURES}

FIGURE

PAGE

1 Distribution of the Portland H11ls S11t, Portland and vicinity, Oregon and Washington . . . . . . 6

2 Sedimentary peel and corresponding radiograph from site \# 3.......................

3 Orfented slab and corresponding radiograph from site \# 3

4 (a) Buried soll horizon (dark band) in the Portland Hills Silt along the Burlington Northern Railroad tracks, north of Cornelius Pass; (b) detail of massive Portland Hills Silt overlying a strongly mottled and streaked paleosol .. . . . . . . . . . . .

5 A succession of loess beds on Banks Peninsula, South Island, New Zealand, containing 6 buried soils . .

6 Road cut, NE $\frac{1}{4} S^{\frac{1}{4}}$, sec. 26, T. IN., R.1W., showing massive Portland Hills Silt unconformably overlying bedded and laminated silt and clayey silt . . . . . .

7 Concretionary root casts ("pipestems") and shot found in the Portland Hills Silt. Note the concentric structure of the root casts. . . . . . . . . . .

8 Photomicrograph contrasting the internal fabric and composition of weathered basalt and concretionary shot 36

9 Typical soll profile developed on Portland Hills Silt showing mottling and jointing .......... 36

10 Slide scarp along NW Cornell Road, NW 4 NW/a, sec. 31, T. 1N., R.IW., showing hydrated iron oxide banding and lamination in the Portland Hills Silt. Note the bluegray unoxidized zone in the lower part of the photograph ....................

11 Same locality as Figure 10. Note the roundish concretionary structures. . . . . . . . . . . .

12 Same locality as Figure 10. The photo shows the local contortions and discontinuities of the iron oxide bands 39 
13 Photomicrograph showing hydrated iron oxide laminations (dark bands) in the Portland Hills Silt. Note the larger silt grains across these cemented zones (X Polars).................. 41

14 Iron oxide layer and possible unconformity in a road cut along SW Taylors Ferry Road, NW $\frac{1}{4} \mathrm{SE}_{\frac{1}{4}}$, sec. 29, T.1S., R. IE.

15 Concretionary structure exposed in Portland Hills Silt along the Baldock Freeway (the road cut has since been covered) . . . . . . . . . . . . . . . . . .

16 Range of cumulative frequency curves of 20 unweathered Portland Hills Silt samples. Also shown is a typical cumulative frequency curve and its corresponding frequency distribution (sample 76-15) . . . . . .

17 Textural boundaries enclosing 95 percent of all Portland Hills Silt samples. Sand, silt and clay ranges were derived by adding and subtracting twice the standard deviation from the mean of each. . . . . . . . 50

18 Photomicrograph showing the fabric of the Portland Hills Silt. Note the poor sorting and random distribution and orlentation of the silt particles (X Polars) . . . 54

19 Mica Orientation in three widespread Portland Hills Silt samples . . . . . . . . . . . . . 55

20 Photomicrograph of Portland Hills Silt quartz grains showing the angularity, extreme relief and variably sized conchoidial breakage patterns which are typical of glacial-fluvial environments . . . . . . . .

21 Photomicrograph of a Portland Hills Silt quartz grain showing typical glacial textures (Krinsley and Donahue, 1968); semiparallel steps (s), arc-shaped steps (c) and imbricated breakage blocks (b)......... 58

22 Photomicrograph of quartz grains from Columbia River sand (Reed Island). Compare these with the Portland Hills Silt grains (Figure 20). . . . . . . . . . . 59

23 Photomfcrograph showing the platy morphology of clay minerals in the Portland Hills S1lt . . . . . . . 73

24 Classification of the Portland Hills Silt according to (a) texture (Folk, 1968, p. 28) and (b) composition (Folk, 1968, p. 128) 
25 Sketch cross section of the Tualatin Mountains showing surficial stratigraphy .............

26 Symbol explanation for Figure 25 . . . . . . . . . 80

27 Road cut along SW Boones Ferry Road, NE出W $\frac{1}{4}$, sec. 33, T.1S., R.1E., showing Portland Hills Silt atop Boring Lava and the Troutdale Formation . . . . . 84

28 Road cut along the Baldock Freeway, NE $\frac{1}{4} \mathrm{SE}^{\frac{1}{4}}$, sec. $30, \mathrm{~T} .1$ S., R.IE., showing Portland Hills Silt overlying weathered Boring Lava. Note the vertical, blocky jointing in the silt. . . . . . . . . . . . .

29 Construction cut at the St. Vincent Hospital (SW Barnes Road) showing Portland Hills Silt overlying Boring Lava 85

30 Road cut showing Boring Lava interstratified with the Portland Hills Silt, near the function of SW Barnes and Miller Roads. . . . . . . . . . . . . 87

31 Section DAH76-1 . . . . . . . . . . . . 139

32 Section DAH76-2 . . . . . . . . . . . . 140

33 Section DAH76-3 .................. . . . . . . . . .

34 Section DAH76-4 ................. 142

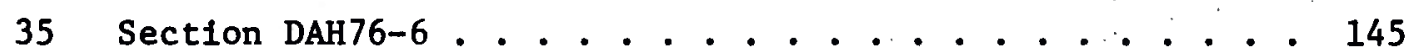

36 Skyline School Section .............. 146

37 Areal variation of the median and mean textural statistics in 20 Portland Hills Silt samples... . . . . . 96

38 Areal variation of averaged sand/clay ratios from 67 Portland Hills Silt samples . . . . . . . . . 97

39 Selected cumulative frequency curves from worldwide loess deposits (Swineford and Frye, 1955a, p. 6; Young, 1967 p. 653) compared with the curve of a typical Portland H11ls Silt sample............... 112

40 Correlation of subsurface data from the Tualatin Mountains 120

41 Correlation of late Cenozolc stratigraphy of western Washington (Birkeland, et al., 1970) and the Tualatin Mountains .............. 121 


\section{INTRODUCTION}

Topics In geology, which Inevitably excite professional discussion and even tempered debate, often present challenging targets for the exploratory jabs of Master's degree candidates. The Portland H1Ils Silt and the controversy concerning its genesis provides just such an object.

The Portland Hills Silt was first named by Lowry and Baldwin In 1952 (p. 7). It is generally described by more recent writers (Beaul1eu, 1971; Niem and Van Atta, 1973) as a massive, structureless and apparently unfform, light yellowish-brown to buff, mlcaceous and clayey silt. The silt is found chlefly above 91-182 $\mathrm{m}(300-600 \mathrm{ft})$, mantling the Tualatin Mountains as well as other adjacent highlands immediately south and west of the Columbia River (Trimble, 1963, p. 51). The thickness of the capping silt varies between 0 and $30 \mathrm{~m}(0-100 \mathrm{ft}$; N1em and Van Atta, 1973, p. 86). It has been alternately assigned to upper Pliocene (Lowry and Baldwin, 1952, p. 12) or lower or middle Pleistocene (Trimble, 1963, p. 32).

Although the physical descriptions of the silt are generally in agreement, they remain somewhat generallzed and, at present, no single definition is generally accepted. Moreover, incongrulties concerning structural and textural details--notably, the presence of minor stratification and/or scattered pebbles in the silt--have resulted in considerable disagreement regarding its mode of origin. The silt has variously been interpreted as (1) water deposited (Diller, 1896, 
p. 485; Libbey, Lowry and Mason, 1945, p. 10; W1lk1nson, Lowry and . Baldwin, 1946, p. 26; Lowry and Baldwin, 1952, p. 11); (2) a product of residual weathering of basalt (Diller and others, 1915, p. 29); (3) a wind-transported deposit (Darton, 1909, p. 11; Libbey, Lowry and Mason, 1945, p. 5; The1sen, 1958, p. 31; Trimble, 1963, p. 52; Schlicker and Deacon, 1967; Livingstone, 1966, p. 46); (4) a combination of fluvial and eolian deposition (Baldwin, 1964, p. 49; Beaulieu, 1971, p. 34 ; N1em and Van Atta, 1973, p. 86), and (5) the result of fluvial, eollan and residual weathering (W111 lams, 1916, p. 14; Treasher, 1942, p. 14). The diversity of these theories, which are so dependent upon the existence or absence of minor, yet very important properties of the sflt, is largely attributable to difficulties inherent in fleld study. Poor exposure is probably the greatest obstacle facing a field geologist in the Portland area. While road cuts, construction excavations, and landslide-scarps offer limited insight into the geology of steep hillside areas, they are virtually useless in more level terrain.

In addition, other poorly indurated deposits of very simflar texture and composition commonly directly underlfe or overlie the Portland Hills Silt. These include the laterized Helvetia Formation (Schlicker and Deacon, 1967, p. 21), the Troutdale equivalent sediments of the Tualatin Valley (Schl1cker and Deacon, 1967, p. 23), and especially the lacustrine Willamette S1lt formation (Allison, 1935). As a consequence, in outcrops where stratigraphic relationships are amblguous or covered, distinguishing one deposit from another is often 1mpossible. To compound the problem, detalled petrologic studies are 
sadly lacking for all but the Willamette Silt sediments, which were examined by Glenn (1965). In fact, due to the likeness in age and appearance (Schlicker and Deacon, 1967, p. 30), particularly within 3-4 meters (8.5-13 ft) of the surface, the exact stratigraphic relationship between Portland Hills Silt and Willamette Silt is not directly known. Most authors believe, however, that the Willamette Silt is the younger of the two (Lowry and Baldwin, 1952, p. 12; Trimble, 1963, p. 52; Schlicker and Deacon, 1967, p. 30).

Field exposures on steeper slopes may be further confounded by small- or large-scale mass-movement. This is especially true on the abrupt eastern flank of the Tualatin Mountains (Portland Hills) where Portland Hills Silt as well as the clayey Helvetia and residual basalt formations are subject to landsliding (Trimble, 1963, p. 76; Schlicker and Deacon, 1967, p. 54).

Resolution of the problems discussed above, as well as a more complete understanding of the nature and origin of the Portland Hills Silt, is contingent upon a thorough petrologic and stratigraphic investigation of that formation. As a means toward this end, the present study was designed to accomplish the following objectives with respect to the Portland Hills Silt:

(1) A complete description to include: macro and micro structures, minerology, texture and fabric.

(2) Definitive stratigraphic relationships, especially with respect to the Willamette Silt and a geologic age of the formation. (3) A proposed explanation of the sedimentary processes and events contributing to the deposition of the silt. 
(4) Comparison and correlation of similar and/or equivalent silts of local and regional extent.

(5) A surficial geologic map of the Tualatin Mountains area.

Finally, the writer believes that the investigation will resolve much of the past confecture concerning the silt's origin, its mode of transport and environment of deposition, and illuminate the late Cenozoic stratigraphy and history of the lower Columbia River basin.

\section{LOCATION AND DESCRIPTION OF THE STUDY AREA}

Although the field investigation for this report included reconnaissance and sampling throughout the Portland-Tualatin Valley region, Oregon and Washington, the area of major geologic mapping was confined to approximately 90 square miles in the vicinity of the Tualatin Mountains. The reasons for this are discussed later.

The Tualatin Mountains are a northwest trending mountain range bordering west Portland, and are locally referred to as the Portland Hills or the West Hills. They form the natural divide between the lower Columbia River Valley and the adjacent Tualatin Valley, which lies to the southwest. The mapped area encloses a major part of the mountains and extends northward from Lake Oswego and terminates just beyond Cornelius Pass, Oregon. It includes parts of four $15^{\prime}$ quadrangles bounded by parallels $45^{\circ} 15^{\prime}$ and $45^{\circ} 45^{\prime}$ north latitude and meridians $122^{\circ} 30^{\prime}$ and $123^{\circ} 00^{\prime}$ west longitude.

Portland, and the adjacent areas in Oregon and Washington, occupy a part of the Puget Trough (Fenneman, 1931) and centers about the broad topographic low at the junction of the lower Columbia and 
Willamette River valleys (Fig, 1). The area encompasses the highlands northeast, east and southeast of the city, Including Prune Hill, Mt. Norway, Ross Mountain, Mt. Scott and the Boring Hills, as well as the lower Sandy and Clackamas River drainages; the Tualatin Valley and the surrounding mountains south, southwest and west of Portland, including the intervening Tualatin Mountains, Petes Mountain, Cooper Mountain, Bull Mountain and the Chehalem Mountains; and to the northwest and north, the eastern flank of the Coast Range, the Columbia River basin and adjacent Vancouver lowlands.

Topography of the region is quite variable and ranges between about $2 \mathrm{~m}$ ( $6 \mathrm{ft}$ ) near the Columbia River to more than $518 \mathrm{~m}$ (1700 $\mathrm{ft}$ ) at the crest of the Tualatin Mountains and $1067 \mathrm{~m}$ (3500 ft) in the western foothills of the Cascade Range. The Portland Hills and other highlands rise from the nearly flat to gently rolling terraced floors of the Columbia, Willamette and Tualatin River Valleys. The upper slopes of these highlands, especially the rather steep, eastern slopes of the Portland Hills, are greatly prized for their scenic overviews. Consequently, in many places these hillsides are densely populated.

The climate of Portland and the surrounding region is moderated by close proximity to the Pacific Ocean. Relatively mild temperatures are characteristic, with minimum temperatures in January averaging above $18^{\circ} \mathrm{C}\left(0^{\circ} \mathrm{F}\right)$ and maximum temperatures during July (the hottest month) averaging below $27^{\circ} \mathrm{C}\left(80^{\circ} \mathrm{F}\right)$. Precipitation is moderately heavy over the area and varies between 89-114 cm (35-45") annually, mainly as rain. Generally the higher elevations receive greater rainfall amounts. 
FIGURE 1. DISTRIBUTION OF THE PORTLAND HILLS SILT PORTLAND AND VICINITY, OREGON, WASHINGTON

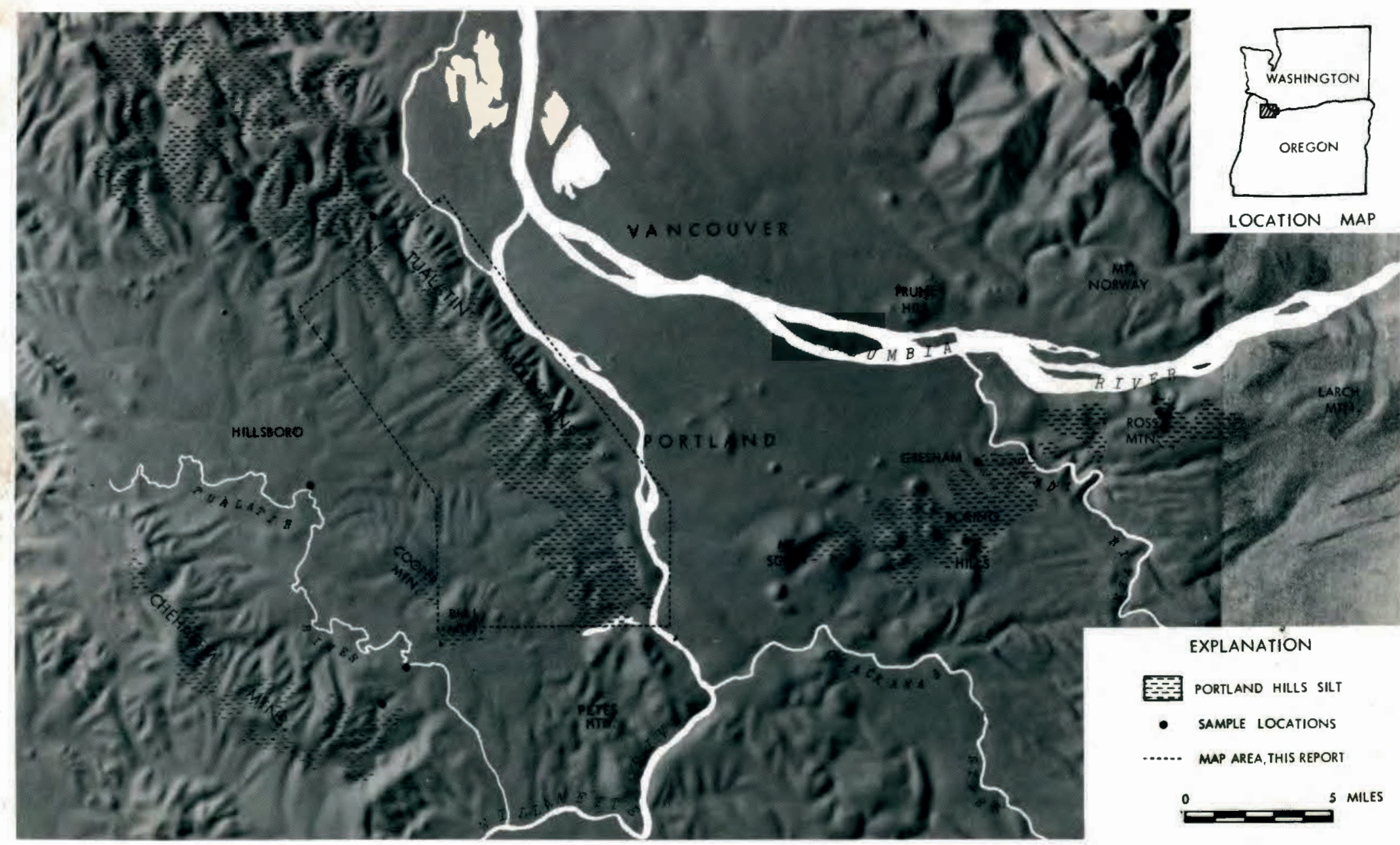


Luxurient vegetative growth is encouraged by the mild climate and abundant rainfal1. Dense undergrowth, particularly in deforested areas, of w1ld blackberry, raspberry, huckleberry, polson oak, nettles, Oregon grape, ferns, alder and vine maple, is the major factor which limits exposures. Main forest trees include Douglas fir, western hemlock, western red cedar, Pacific dogwood, bigleaf maple, Oregon ash, red alder, cascara buckthorn, Pacific madrone and Oregon white oak.

\section{GEOLOGIC SETTING}

The oldest known rocks exposed in and underlying the Portland region are the late Eocene to early Miocene altered volcanic rocks and marine sedimentary formations. The marine sedimentary rocks are exposed mainly in a broad, arc-shaped patch which originates in the Chehalem Mountains and curves about the eastern and northern margin of the Tualatin Valley. They consist largely of sandstone and siltstone and include undifferentiated Eocene volcanics and sediments, the upper Eocene Yamhi11 and Spencer formations, undifferentiated Oligocene marine sediments mentioned by Schlicker and Deacon (1967, p. 11-17) and the Oligocene Scappoose formation (Trimble, 1963, p. 14). The latter two, undifferentiated 01igocene sediments and the Oligocene Scappoose formation, are probably correlative (Beaulieu, 1971, p. 40). Altered basaltic and andesitfc volcanic rocks exposed east and north of Prune Hill, Washington; were named the Skamania Volcanic Series by Felts (1939). These are described in some detail by Trimble (1963, p. 11). The series is considered late Eocene to early Miocene in age and may be correlative in part to Schlicker and 
Deacon's undifferentiated Eocene volcanics and sediments.

Over much of the Portland area these older rocks are overlain unconformably by a thick pile of middle Miocene flood basalts. Individual flows are relatively thin and consist of dense, black to dark-gray basalt. Collectively, the lavas are known as the Columbia River Group (Beaulieu, 1971, p. 12), but more often they are simply called Columbla River Basalt (Trimble, 1963, p. 19; Schlicker and Deacon, 1967, p. 17; Niem and Van Atta, 1973, p. 83). Trimble (1963, p. 20) reported data from several dr111 holes indicating a thickness of between 210-300 m for the basalt in the Portland Hills and Tualatin Valley regions. It commonly crops out on the steeper highland slopes and in stream canyons.

Large scale deformation of the newly formed basalt surface occurred during the uplift of the Cascade Range and the subsidence of the Willamette Valley region. Local tectonism in the Portland area also produced major topographical features. These include the Tualatin, Chehalem, Cooper and Bull mountain anticlinal structures, and the Tualatin Basin (Schlicker and Deacon, 1967, p. 36). Beeson, Johnson and Moran (1975) recently completed a detailed study of the structure and stratigraphy of the Columbia River Basalt in the south Portland area. They report a complexly folded and faulted zone extending southeastward from, and aligned with, the Portland Hills. Major faulting of this zone trends $N 35^{\circ} \mathrm{W}(\mathrm{p} .72)$ and includes the Portland Hills fault, a major right lateral fault located along the eastern base of the Portland Hills (p. 34). Beeson and his colleagues describe the Portland Hills as a complex anticlinal structure 
consisting of three subparallel folds (p. 72).

As deformation of the Columbia River Basalt continued its upper surface was deeply weathered and laterized (Trimble, 1963, p. 21). The laterite and fresher rock is exposed at the surface or beneath younger deposits in the structural highlands west of Portland.

Unconformably overlying the Columbia River Basalt and filling the Willamette and Tualatin structural basins are thick lacustrine and fluvial sediments of lower Pliocene age (Trimble, 1963). These include laterized pebbly silt, clay and sand of the Helvetia formation (Schlicker and Deacon, 1967, p. 21), bedded f1ne-grained sand-, s1lt-, and claystone of the Sandy Rfver Mudstone (Trimble, 1963, p. 26), and quartzite bearing conglomerate of the Troutdale formation (Trimble, 1963, p. 29). The weathered Helvetia sediments directly overlie the basalt in the Tualatin Valley region, where they are considered to be correlative to the Sandy River Mudstone (Schlicker and Deacon, 1967, p. 22) .

Interbedded with the Troutdale gravels in the Portland area are vitr1c sandstone and fine, silt and clay phases (Trimble, 1963, p. 31). In the Tualatin Valley, however, the Troutdale equivalent sediments consist chiefly of stratlfied fine-sands and silts and, rarely, gravels (Schllcker and Deacon, 1967, p. 23). Thus, the lithological break between the Sandy River Mudstone and the Troutdale proper is not apparent in that section.

The Sandy River Mudstone and Troutdale formations underlie the Portland area and the Tualatin Valley at depths to about $520 \mathrm{~m}$ (1700 ft; Lowry and Baldwin, 1952, p. 9) and $460 \mathrm{~m}$ (1500 ft; Schlicker and 
Deacon, 1967, p. 23) respectively. They are exposed around the margin of the Portland area in stream cuts and on steeper slopes, and overlie weathered or eroded Columbia River Basalt. Helvetia and Troutdale equivalent sediments in the Tualatin Valley are exposed in a like manner.

Troutdale gravels are present locally at elevations of up to $183 \mathrm{~m}$ (600 ft; Hart and Newcomb, 1965, p. 19) and probably $230 \mathrm{~m}$ (750 ft; Wilkinson, Lowry and Baldwin, 1946, p. 25) on the east flank of the Tualatin Mountains. And, although equivalent sediments of the Tualatin Valley lap high onto the western flank of the hills (Schlicker and Deacon, 1967), thelr fine-grafned character and the scarcity of gravels indicate that the Tualatin Mountains had already largely been formed (Hart and Newcomb, 1965, p. 19; Lowry and Baldwin, 1952, p. 10). Beginning in late Tertiary time numerous volcanic eruptions took place in the Portland area (Trimble, 1967, p. 36). Treasher (1942a, p. 10) named the products of these volcanoes the Boring Lava. It is comprised chiefly of medium gray, open textured olivine basalt with local tuff, breccia, cinder and scoriaceous phases (Trimble, 1963, p. 36). The rock is exposed at higher elevations where it commonly forms cone-shaped vents such as: Mt. Scott, Mt. Sylvania and Swede Hill or high lava plains, like those south of Oregon City (Trimble, 1963, p. 36). It also crops out along the western slope of the Tualatin Mountains, in the Boring H1lls, on Chamberlain H111, Crown Point and in Washington on Mt. Norway and near Prune Hill. Boring volcanics generally overlie the eroded or weathered Troutdale and older formations. However, in at least two localities it is reported to be 
interbedded with Troutdale gravels (Lowry and Baldwin, 1952, p. 10; Treasher, 1942a, p. 10; Wilkinson, Lowry and Baldwin, 1946, p. 25). A late Pliocene to early (Treasher, 1942a, p. 9) or late (?) Pleistocene (Trimble, 1963, p. 42) age has been assigned to the Boring Lava. Beaulieu (1971; p. 6) suggested, however, that the younger, middle and late Pleistocene rocks may be more properly considered part of the Cascades formation, which crops out farther east.

Southeast and east of Portland, Boring Lava and the weathered and eroded Troutdale Formation are overlain by a series of Plio-Pleistocene piedmont and terrace deposits (Trimble, 1963, pp. 43-58). These formations are composed predominantly of fluvial gravel (without quartzite) and mudflow deposits. They include, from oldest to youngest, the Walters Hi11, Springwater, Gresham and Estacada formations. The Walters H111 Formation occurs locally near Mt. Scott and in the Boring Hills above elevations of about $122 \mathrm{~m}$ (400 ft). The deeply weathered Springwater deposits, on the other hand, are widely exposed in the high, terraced surface adjacent to, and between the Sandy and Clackamas Rivers. The younger Gresham and Estacada formations are generally confined to the Sandy and Clackamas River valleys.

Late Quaternary geology in the region was marked by widespread deposition of lacustrine deposits in the Willamette, Tualatin, and lower Columbia River valleys (Trimble, 1963, p. 58). Up to $15 \mathrm{~m}$. (50 ft) of stratified silts and sands mantle older formations in the Willamette and Tualatin valleys up to elevations of about $107 \mathrm{~m}$ (350 ft; Glenn, 1965, p. 141). Allison (1953, p. 12) proposed the name Willamette Silt for these sediments. Coarser deposits in the Portland 
basin, which are thought to be equivalent (Trimble, 1963, p. 58), are dominated by poorly stratified sand and gravel:

\section{PREVIOUS WORK}

A wide variety of terms have been used to label the sediments of the Portland Hills Silt. This is indicative, perhaps, of the complexity or, at least, the uncertainty of the subject.

Table 1 was constructed to facilitate a comparison of that data presented by previous workers concerning sediments which are wholly or partially equivalent to the Portland Hills Silt. It summarizes the nomenclature, structure, composition (especially stratification and pebble content), thickness, age and origin of those sediments according to each author. In addition, the chart lists those recently named formations (e.g., Helvetia, Willamette Silt, etc.) which were probably Included in each unit as it was originally defined.

Prior to 1952, when Lowry and Baldwin first named the Portland Hills Silt, its origin and the origin of similar silts in the Portland area were already a subject of wide speculation. As early as 1896, J. S. Diller (p. 485) reported a "fine argillaceous sediment" which closely resembled the loess of the Mississippi Valley. The material was found covering the east flank of the Portland Hills at elevations of up to nearly $200 \mathrm{~m}(660 \mathrm{ft})$. In places the deposit was "distinctly stratified" and he assumed, therefore, that it was water-laid.

Some eleven years later, N. H. Darton (1907, p. 11) described the same sediment as a "thick mass of fine-grained porous silt." He disagreed with Diller, however, and inferred the silt to be of eolian 
TABLE 1

PREVIOUS DESCRIPTIONS OF THE PORTLAND HILLS SILT

\begin{tabular}{|c|c|c|c|c|c|c|c|c|c|c|c|}
\hline & $\begin{array}{l}\text { Diller } \\
\text { (1896) }\end{array}$ & $\begin{array}{l}\text { Darton } \\
(1909)\end{array}$ & $\begin{array}{l}\text { Treasher } \\
(1942)\end{array}$ & $\begin{array}{c}\text { Lilbey, Lowry } \\
\text { and Mason } \\
(14,5)\end{array}$ & $\begin{array}{l}\text { Wilkinson, } \\
\text { Lowry and } \\
\text { Baldwin (1946) }\end{array}$ & $\begin{array}{c}\text { Lowry and } \\
\text { Baldwin } \\
\text { (1952) }\end{array}$ & $\begin{array}{l}\text { The isen } \\
\text { (1958) }\end{array}$ & $\begin{array}{l}\text { Howe II } \\
(1962)\end{array}$ & $\begin{array}{c}\text { Trimble } \\
\text { (1963) }\end{array}$ & $\begin{array}{l}\text { Livinoston } \\
(1966)\end{array}$ & $\begin{array}{c}\text { Schlicker } \\
\text { and Deacon } \\
(196,7)\end{array}$ \\
\hline $\begin{array}{c}\text { Study } \\
\text { Location }\end{array}$ & $\begin{array}{l}\text { Northivest } \\
\text { Oregon }\end{array}$ & $\begin{array}{c}\text { Washington } 6 \\
\text { Oregon }\end{array}$ & $\begin{array}{c}\text { Portland: } \\
\text { Oregon } \\
\text { Area }\end{array}$ & $\begin{array}{c}\text { Nort hwestern } \\
\text { Oregon }\end{array}$ & $\begin{array}{l}\text { St. Helens } \\
\text { Quadrangle }\end{array}$ & $\begin{array}{l}\text { Lewar } \\
\text { Columbia. } \\
\text { River valley }\end{array}$ & $\begin{array}{c}\text { Nor thwestern } \\
\text { Oregan }\end{array}$ & $\begin{array}{l}\text { Lower } \\
\text { Columbia } \\
\text { River Valley } \\
\end{array}$ & $\begin{array}{c}\text { Port land, or } \\
\text { and adjacent } \\
\text { areas }\end{array}$ & $\begin{array}{l}\text { Kelso- } \\
\text { Cathlamet } \\
\text { area, Wash. }\end{array}$ & $\begin{array}{l}\text { Tualatin } \\
\text { valley } \\
\text { Region }\end{array}$ \\
\hline $\begin{array}{l}\text { Primary } \\
\text { Structures }\end{array}$ & $\begin{array}{l}\text { Loess-like } \\
\text { distinctly } \\
\text { stratified } \\
\text { lacally }\end{array}$ & Loess-like & $\begin{array}{l}\text { Massive. } \\
\text { Locally } \\
\text { finely } \\
\text { laminated }\end{array}$ & Massive & Massive & $\begin{array}{l}\text { Massive. } \\
\text { minar } \\
\text { stratifica- } \\
\text { tion }\end{array}$ & $\begin{array}{l}\text { No } \\
\text { structure } \\
\text { reforied }\end{array}$ & $\begin{array}{l}\text { Massive and } \\
\text { stratified }\end{array}$ & $\begin{array}{l}\text { massive. } \\
\text { no stratifi- } \\
\text { cation }\end{array}$ & $\begin{array}{l}\text { Massive } \\
\text { except for } \\
\text { separation } \\
\text { of upper and } \\
\text { lower units }\end{array}$ & Massive \\
\hline Texture & $\begin{array}{l}\quad \text { Uniform, } \\
\text { fine, argi - } \\
\text { laceous } \\
\text { sediment }\end{array}$ & $\begin{array}{l}\text { Uniform } \\
\text { Porous } \\
\text { silt }\end{array}$ & $\begin{array}{l}\text { Uniform, } \\
\text { contains } \\
\text { sonie sand }\end{array}$ & $\begin{array}{l}\text { Uniform, } \\
\text { contains } \\
\text { pebbles in } \\
\text { places }\end{array}$ & $\begin{array}{l}\text { Uniform, } \\
\text { scattered } \\
\text { well-rounded } \\
\text { quartzite } \\
\text { pebbles }\end{array}$ & $\begin{array}{l}\text { Uniform, } \\
\text { scatterid } \\
\text { quartzite and } \\
\text { mafic } \\
\text { peboles }\end{array}$ & $\begin{array}{l}\text { Uniform, } \\
\text { no pebbles } \\
\text { reported }\end{array}$ & $\begin{array}{l}\text { Un iforar. } \\
\text { sorre gravel } \\
\text { lenses }\end{array}$ & $\begin{array}{l}\text { Uniform, } \\
\text { sone coilu- } \\
\text { vial pebbles }\end{array}$ & $\begin{array}{l}\text { Upper memiler: } \\
\text { silt and } \\
\text { clayey silt } \\
\text { Luwer nember: } \\
\text { silty clay } \\
\text { and clay }\end{array}$ & $\begin{array}{l}\text { Unif orin, } \\
\text { occasional } \\
\text { well -rounded } \\
\text { tasalt } \\
\text { mebbles }\end{array}$ \\
\hline Thickness & $?$ & $0-300 \mathrm{ft}$ & $0-100 \mathrm{ft}$ & $0-40 \mathrm{ft}$ & $0-100 \mathrm{ft}$ & $0-300 \mathrm{ft}$ & $\cdots$ & - & $0-100 \mathrm{ft}$ & $25-40 \mathrm{ft}$ & $0-55 \mathrm{ft}$ \\
\hline $\begin{array}{l}\text { Strati- } \\
\text { graphy }\end{array}$ & $\cdots$ & -- & $\begin{array}{l}\text { Heavy silt } \\
\text { cover over } \\
\text { most of the } \\
\text { Port land area }\end{array}$ & $\begin{array}{l}\text { Overlies } \\
\text { ferruginous } \\
\text { bauxite } \\
\text { deposits in } \\
\text { northern } \\
\text { Tualatin } \\
\text { Mtns. }\end{array}$ & $\begin{array}{l}\text { Upper } \\
\text { Member of the } \\
\text { Trout Jale } \mathrm{fm} \text {. }\end{array}$ & $\begin{array}{l}\text { Uwper } \\
\text { Member of the } \\
\text { Troudale fm. }\end{array}$ & $\begin{array}{l}\text { Overlies } \\
\text { residual } \\
\text { soils }\end{array}$ & $\begin{array}{l}\text { Two units: } \\
\text { an older } \\
\text { massive unit } \\
\text { and a younger } \\
\text { stratified } \\
\text { unit }\end{array}$ & $\begin{array}{l}\text { Overlies the } \\
\text { 5pringwater } \\
\text { and older fms. } \\
\text { but is over- } \\
\text { lain by the } \\
\text { Gresham and } \\
\text { younger fors. }\end{array}$ & $\begin{array}{l}\text { Two units: } \\
\text { a weathered } \\
\text { lower unit, } \\
\text { and an upper } \\
\text { unweathered } \\
\text { unit }\end{array}$ & $\begin{array}{l}\text { Overlies } \\
\text { Boring Lava } \\
\text { and older } \\
\text { fms. } \\
\text { Parily equiv- } \\
\text { alent to } \\
\text { earliest } \\
\text { Willasette } \\
\text { Silt } \\
\end{array}$ \\
\hline Name & -- & -- & silt & -- & - & $\begin{array}{l}\text { Portland } \\
\text { Hills Silt }\end{array}$ & $\begin{array}{c}\text { Loess-like } \\
\text { parent mater. }\end{array}$ & $\begin{array}{l}\text { Portland } \\
\text { Hilis } 5: 1 t\end{array}$ & Loess & $\begin{array}{l}\text { Post-Troutdaie } \\
\text { silty clay }\end{array}$ & $\begin{array}{l}\text { Up land } \\
\text { sile }\end{array}$ \\
\hline Age & -- & - & $\begin{array}{l}\text { Late Pleist- } \\
\text { ocere to } \\
\text { early Recent }\end{array}$ & - & $\begin{array}{l}\text { Late } \\
\text { Oliorene }\end{array}$ & $\begin{array}{l}\text { Late Pliocene } \\
\text { (early Pleist } \\
\text { ocene) }\end{array}$ & $\begin{array}{l}\text { Ple is tocene } \\
\text { or younger } \\
\end{array}$ & $\cdots$ & $\begin{array}{l}\text { Early (?) and } \\
\text { middle } \\
\text { pleistocene }\end{array}$ & $\begin{array}{c}\text { Post- } \\
\text { Troutdale }\end{array}$ & $\begin{array}{l}\text { Lower tu } \\
\text { upper Pleist- } \\
\text { ocene }\end{array}$ \\
\hline $\begin{array}{c}\text { Mode } \\
\text { of } \\
\text { Deposition }\end{array}$ & Water-laid & Wirnd-laid & $\begin{array}{l}\text { Complex- } \\
\text { water-. wind- } \\
\text { laid and } \\
\text { residual }\end{array}$ & $\begin{array}{l}\text { Wint and/or } \\
\text { water-laid }\end{array}$ & Wạter-laid & Water-laid & Wind-laid & water-laid(?) & wind-laid & Wind-laid & wind-laid \\
\hline $\begin{array}{l}\text { Included } \\
\text { aecently } \\
\text { Defined firms. }\end{array}$ & Helvetia (?) & Helvetia (?) & $\begin{array}{l}\text { Willamette } \\
\text { silt, Helvetid } \\
\text { and residual } \\
\text { basalt soils }\end{array}$ & -- & -- & Helvetia & $\cdots$ & $\begin{array}{l}\text { Will ansette } \\
\text { Silt (?) }\end{array}$ & -. & Helvetia & $\cdots$ \\
\hline
\end{tabular}


origin. Thus began a historical and, to this date, unresolved debate. Following Diller and Darton, Ruzek (1922), Treasher (1942a), Libbey, Lowry and Mason (1945) and Wilkinson, Lowry and Baldwin (1946) progressively offered more data on the silty deposits. Their contributions are summarized in the succeeding paragraphs.

Ruzek (1922) mapped part of the Portland Hills Silt as the Powell Silt Loam in a soils survey of Multnomah County. The soil was characterized, he said, by small rounded pellets or "shot" consisting usually of silt particles cemented together by iron oxide. Ruzek. believed that the material was at least partly deposited by a youthful Columbia River as it flowed at a higher elevation.

Treasher (1942a, p. 14) briefly described a "heavy silt cover" which covered "practically the entire (Portland) area to depths ranging from a few inches to as much as a hundred feet." He reported it to be "textureless", but locally "finely laminated" and "not as typically loesslike as that in the Palouse region." He suggested a complex origin for the material involving residual weathering, as well as fluvial and eolian deposition in late Pleistocene or recent time. It is likely that Treasher included in this silt parts of what was later called the Helvetia and Willamette Silt formations as well as the Portland Hills Silt.

Libbey, Lowry and Mason (1945, p. 9) described a "massive, finegrained buff to reddish brown silt" which overlaid ferruginous bauxite deposits in the northern part of the Tualatin Mountains. In a subsurface investigation of the Hutchison-Nixon bauxite locality (Pp. 37-43) about 11 miles north of Hillsboro, they show an average 
and maximum thickness for the silt of about $5.4 \mathrm{~m}(18 \mathrm{ft}$ ) and $9 \mathrm{~m}$ (30

ft) respectively. Concerning the silt's origin they state:

The massive, unconsolidated character, mineralogic composition, fineness of grain size, light color, and topographic distribution of the silt suggest it was wind-laid. (However) - . One well-rounded quartzite pebble and one basaltic pebble were found near the surface of the pit face at the Columbia Brick Works at Sylvan and according to the operator, such pebbles occur in place in the silt. The presence of these pebbles seemingly in place in the silt indicates that part and possibly all of it may have been laid down in water and subsequently subjected to folding. (p. 10)

In 1946, Wilkinson, Lowry and Baldwin (p. 24-27) reported a similar massive silt, mantling parts of the Tualatin Mountains in the St. Helens Quadrangle, northwest of Portland. A maximum of $30 \mathrm{~m}$ (100 $\mathrm{ft}$ ) of silt was found to overlie weathered and unweathered Troutdale gravels and sands and in large part, weathered and laterized Columbia River Basalt. Random quartzite and weathered basalt pebbles and cobbles were discovered in the silt where it overlay Troutdale conglomerate ( $p .25)$. A microscopic examination reported by. Wilkinson and his assoclates (p. 26) showed: ". . a varlety of angular mineral grains ranging in maximum dimension from less than $0.05 \mathrm{~mm}$ to more than $0.15 \mathrm{~mm} . "$ These included muscovite, biotite, microcline, plagioclase, quartz, augite, hornblende, magnetite, tourmaline, garnet, apatite, tremolite, "some other mineral particles". . "two genera of diatoms and several sponge spicules." Due to the presence of pebbles, diatoms and sponge spicules they hypothesized a water-laid origin for the silt, and tentatively described it as the "silty upper phase" of the Troutdale formation.

Lowry and Baldwin's (1952) publication on the late Cenozoic 
geology of the lower Columbia River valley generally continued where Wilkinson and his companions left off. They proposed the name "Portland Hills Silt" ( $p .7)$ for the "stratigraphically younger and more widespread silt member" of the Troutdale formation. They admitted, however, that the distinctive silt might unconformably overlie the Troutdale formation proper and might prove, then, to be of "formational rank."

Describing the silt, Lowry and Baldwin (1952, p. 11) wrote:

In most roadcuts where the Portland Hills Silt has been exposed, it is a structureless, 11ght-brown or yellowish-brown mass which in the upper part may be mottled with gray streaks. In deep cuts, the light-brown silt is seen to grade down into a reddish-brown clayey silt. The silt is surprisingly uniform in grain size and in only a few places has a suggestion of stratification been noted.

In addition to those minerals identified by Wilkinson and his associates (1946), Lowry and Baldwin (1952, p. 11) reported hypersthene and a few grains of volcanic glass in the silt. : Scattered we11rounded quartzite pebbles were also reported to occur in the deposit along the crest of the Portland Hills and in similar silts on Ross Mountain and near. Longview and Cathlamet, Washington (p. 11-12):"The presence of these pebbles led Lowry and Baldwin to believe that the Portland Hills Silt was water deposited. They theorized (p. 11) that both the Troutdale gravels and the "thick". Portland Hills Silt were deposited during Pliocene time, when a eustatic rise in sea level caused submergence and aggradation of the Columbia River. Continued deformation and uplift, they added, was probably greatly responsible for the unusual topographic distribution of the silt at elevations between about $107 \mathrm{~m}$ (350 ft) and more than $343 \mathrm{~m}$ (1125 ft). Without 
folding, they noted, a total stratigraphic thickness of greater than $213 \mathrm{~m}$ (700 ft, p. 11) would be implied.

Lowry and Baldwin (1952, p. 12) correlated the Portland Hills silt with mineralogically and texturally similar deposits east of the Cascade mountains. These included the Ringold formation (Merriam and Buwalda, 1917) of south-central Washington and the Palouse formation (Treasher, 1925) of southeastern Washington and Idaho.

The theory of deposition by water was again challenged in 1958. Theisen (1958) referred to the Portland Hills Silt as a "loess-like soil parent material" in his study of the distribution and characteristics of that material in northwestern Oregon. He (p. 13) carefully excluded the lower "typically reddish brown," clayey silt noted by Lowry and Baldwin (1952, p. 11) from the lighter colored loess-like deposit which overlay it.

Theisen was first to show the distribution of the "loess" on the uplands of northwestern Oregon. He also reported (p. 32) a general thinning of the deposit southward and westward away from the Columbia River. Because of the character and distribution of the deposit, Theisen concluded that strong northeast winds, possibly during glacial Pleistocene time, had transported the silt from the flood plain of the Columbia River and deposited it upon the adjacent highlands.

Several years after Theisen's work, fresh railroad and highway cuts in the Portland area inspired a brief article by Paul Howell (1962, P. 17-20). He suggested that the Portland Hills Silt actually. consisted of two members: an older and better known "massive silt" and a younger, "well stratified" unit. While the "massive" silt 
extended to the crest of the Tualatin Mountains, Howell reported the presence of the "younger silts" as high as $183 \mathrm{~m}$ (600 ft) but mainly below about $107 \mathrm{~m}$ (350 ft) in the Tualatin Mountains and north of Vancouver, Washington.

In his concluding remarks Howell summarized the questions which had been implied by Lowry and Baldwin (1952). Though -. . the evidence against eolian origin (for Portland Hills Silt) is becoming overwhelming . . . there remains yet to be explained the erosional removal of such large masses of the formation as once existed here in the lower Willamette and Columbia River valleys, and why remnants, of the silt still persist on ridge noses and summits of the adjacent mountains.

Trimble (1963) resolved these problems in his work by postulating an eolian origin for the silt. What he called "loess" was equivalent to the upper "11ght brown silt" of Lowry and Baldwin's (1952) Portland

Hills Silt member and was described as follows:

The loessial deposits are yellowish-brown clayey, sandy silt, which is homogeneous and structureless. No stratification has been observed in this material by the author. Locally pebbles have been found near the base of the deposit, that are believed to represent colluvial contributions from adjacent conglomerate of the Troutdale formation during the accumulation of the loess. (p. 51)

He noted also that a podzolic soil profile was commonly developed upon the "loess." It was characterized by shotlike concretions and a blocky or polygonal structure, which served to distinguish the deposit from similar silts.

The "loess" was reported ( $p$. 50) to mantle Mt. Scott and the hills near Corbett and in the Boring-Gresham area, and also formed an "extensive cover on the Tualatin Mountains." A maximum known thickness of $17 \mathrm{~m}(55 \mathrm{ft})$ was determined for the deposit on the crest of the 
Portland Hills. At least $30 \mathrm{~m}(100 \mathrm{ft})$ of silt was inferred at a locality near the Sandy River (p. 51). Areas in which the deposit was greater than $5 \mathrm{ft}$ deep were mapped by Trimble (1952) and shown as an overprint on his geologic map.

Trimble (1952, p. 52) suggested an early or middle Pleistocene age for the "loess" because it covered the early Plefstocene Walters H111 and Springwater formations but was absent above the younger. Gresham and Estacada terrace formations. He (p. 52) discussed the previous theories concerning the origin of the silt, but decided that It was wind-1aid for the following reasons:

(1) the conformity of the silt mantle to preexisting topography, (2) the lack of stratification in the deposits, (3) the distribution of the deposits only south and west of the Columbia River flood plain, (4) the thinning of the silt away from the Columbla River flood plain, and (5) the general lack of widespread contemporaneous water-deposit sediments at equivalent altitudes.

A year later, in 1964, Baldwin (p. 49) referred to the distinctive deposits as the Portland Hills Silt formation. He reiterated much of the information given by Lowry and Baldwin (1952), and further suggested that the silt might be partly interbedded with Plio-Pleistocene Boring Lava. Baldwin (1952, p. 49) mentions Trimble's (1963) hypothesis for the silt's origin, but is still troubled by the presence of pebbles in the formation. He finally concludes that "It is possible that both water-laid and windblown silt are present."

Baldwin (1964) also reported upon the only mega-fossil which is thought to have been recovered from Portland Hills Silt--a worn mammel's tooth discovered in 1898. The fossil, though first identified as a camel's tooth by Washburne (1914), had since been reidentified by 
J. A. Shotwell as the tooth of a middle Pliocene rhinoceros. This Indicated at least a middle Pliocene age for the silt from which the tooth came. However, Beaulieu (1971, p. 34) cast some doubt upon this data. He stated:

Admittedly, however, the exact stratigraphic position of the specimen (rhino fossil tooth) has never been determined, and hence it may not have occurred in the Portland Hills Silt. The possibility also exists that the original tooth became inadvertently exchanged for another similar fossil between the time that it was first collected and the time that it was finally. identified years later.

North of Portland, in the Kelso-Cathlamet area, Livingstone (1966) mapped patches of "wind-transported" silt which he tentatively correlated with Trimble's "loess.". He called the deposits "PostTroutdale silty clay" and noted that they consisted of two units: an upper light brown to reddish silt or clayey silt, and a lower, "thoroughly weathered and oxidized" mottled red brown and gray, silty clay. The material varied between 25 and $40 \mathrm{ft}$ in total thickness and it unconformably overlay Columbia River Basalt, ferruginous bauxite and sedimentary rocks.

The upper silty member described by Livingstone (1966) is likely equivalent to the Portland Hills Silt. Similarly, the lower, thoroughly weathered member is probably correlative to the Helvetia formation which is described below.

Schlicker and Deacon (1967, p. 21) proposed the name Helvetia Formation for deeply weathered and laterized pebbly sand, silt and clay which crops out about the perimeter of the Tualatin Valley. They (p. 30) belleved the laterized Helvetia Formation to be equivalent to the "red brown clayey silt" of Lowry and Baldwin's "Portland Hills 
S11t member" (1952, p. 11) and probably much of the weathered, red clayey deposits which were previously called laterized basalt by Trimble (1963, p. 52) and others. The Helvet1a, they noted (p. 22), contalned foreign minerals such as quartz and mica which could not have been derived from the weathering of basalt.

The term "Upland S11t" was used by Schlicker and Deacon (1967, p. 30) for the texturally and mineralogically uniform silts corresponding to the upper "light brown silt" of Lowry and Baldwin's "Portland H11ls Silt (member)" (1952, p. 52) and the "loess" of Trimble (1963). Schlicker and Deacon (1967, p. 30) described the Upland silt as "similar and indistinguishable from the Willamette Silt except for its occurrence at elevations above $76 \mathrm{~m}(250 \mathrm{ft})$ " (Schlicker and Deacon mapped Willamette Silt up to about $76 \mathrm{~m}$ (250 ft) elevation in the Tualatin Valley whereas Glenn (1965, p. 141) reported that the silt occurs up to about $107 \mathrm{~m}(350 \mathrm{ft})$ in the Willamette Valley).

Although they discovered "occasional well-rounded basalt pebbles" in the upland silt, Schlicker and Deacon supported a loessial origin to the material.

More recent writers such as Beaulieu (1971) and Niem and Van Atta (1973) have retained the name Portland Hills Silt for the controversial formation. A synopsis of their descriptions of the deposit was used in the introduction of this report.

Each of these latter writers implied a complex origin for the silt, which included both fluvial and eolian processes.

The Portland Hills Silt, as defined in the present study, includes all sediments which are equivalent to the "loess" of Trimble (1963) and 
the Upland silt of Schlicker and Deacon (1967). It specifically excludes the older, laterized Helvetia formation described by Schlicker and Deacon (1967).

\section{FIELD METHODS AND SAMPLING PROCEDURES}

A major portion of the field effort was spent in mapping the Tualatin Mountain region. The size and location of this mapped area was chosen for the following reasons: (1) the necessity for a smallscaled, detailed investigation rather than a large, generalized study; (2) the extensive silt cover mantling the Tualatin Mountains (Lowry and Baldwin, 1952, p. 10; Trimble, 1963, p. 50); (3) the relative abundance of hillside, road and construction cuts; and (4) the engineering aspects of the silt's areal distribution in that area, especially on sloped and potentially unstable building sites.

In the field, emphasis was placed upon identification and mapping of the Portland Hills Silt, controlled sampling of the deposit, and detailed observation of outcrops--particularly stratigraphic relationships, sedimentary structures and unusual constituents (i.e., pebbles) of the formation. More than 300 road cuts, excavation sites and slide scarps, exposing Portland Hills Silt, were carefully examined during the field study. The depth of these exposures ranged from less than 2 to nearly $30 \mathrm{~m}$, with a mean of approximately $4 \mathrm{~m}$. The breadth of the outcrops also varied widely; most, however, were $15 \mathrm{~m}$ (50') or more in length.

Minor reconnaissance and sampling outside of the mapped area were undertaken largely for two reasons: to verify the presence or absence 
of the silt as it was mapped in the Portland-Vancouver area by previous workers, and to compare 11 thologically and stratigraphically similar or equivalent sediments in the same area.

Samples collected during the course of the field study were of three main types: (1) uniform depth samples, (2) variable depth samples, and (3) oriented samples.

Uniform and variable depth samples were taken either by channel sampling from outcrop, or by hand augering. Both techniques (channel and auger) produced a composite sample taken from a vertical interval $30 \mathrm{~cm}$ (12") in length. All samples were placed in labeled paper bags and allowed to dry at room temperature before analysis.

Uniform depth samples were consistently taken from generally unweathered, near surface material at depths between 1.5 to $2.1 \mathrm{~m}$ (5-7 ft). In addition to widespread outcrop samples of the Portland Hills Silt, this group included a few representative specimens from the Willamette silt, Helvetia, residual basalt and fine-grained Troutdale formations. Samples collected at uniform depth were analyzed for the following purposes: (1) Definition of compositional and textural characteristics of the Portland Hills Silt and the lateral variation thereof; (2) Comparison of the Portland Hills Silt with similar deposits and (3) Confirmation of field identification, especially at ambiguous exposures.

Likewise, the collecting procedures for the variable depth samples were designed to detect stratigraphic changes in the texture and/or composition of the Portland Hills Silt, and to help ascertain the stratigraphic relationships between it and the Willamette Silt. 
Samples of this type were collected at regular intervals to depths of 4.6 to $13.7 \mathrm{~m}(15-45 \mathrm{ft})$ from 6 princlpal stratigraphic sections.

A number of orlented specimens were obtalned from selected exposures throughout the mapped area for fabric analysts. Since undlsturbed specimens were preferred, sample localitles were chosen on the basis of their apparent slope and surface stabllity. About a $10 \times 15 \mathrm{~cm}$ vertical surface was first prepared in the unweathered silt at a 2-3 $\mathrm{m}$ depth. The strike of this plane and a vertical arrow were then marked on the surface and a block of material cut out from behind it. The specimens were then placed in marked paper bags and allowed to air-dry.

Other orlented specimens were taken using the same procedure for purposes of analysis and identification of sedimentary structures. 


\section{LITHOLOGY}

STRUCTURE

\section{Laboratory Procedures}

A number of sedimentary peels and orfented silt specimens were collected from the Portland Hills Silt to supplement the fleld data.

Three vertical peels measuring 42 by $42 \mathrm{~cm}$ were prepared from road cuts at three separate localities (see Appendix E) using standard techniques. The peels sampled apparently structureless Portland Hills Silt at depths between $2-11 \mathrm{~m}(6-37 \mathrm{ft})$.

Oriented silt specimens were also dug from each of the peel sites. After air drying, each of these specimens was cut into smaller, evenslzed blocks. A $5 \mathrm{~mm}$ thick section was then sliced from each block. Finally, j1gsaw puzzle-like, composite slabs measuring up to $15 \times 25 \mathrm{~cm}$ were pleced together from the sections of each sample.

Radiographs of sedimentary peels and composite slabs were obtained using Kodak type RP film in a Faxitron X-ray machine. Peels were placed upon the $x$-ray film cassette for exposure, while the slabs were arranged on a thin sheet of paper lying directly on top of the film. Best results were obtained with an exposure time of 75 seconds at 15 kllovolts and 1.0 milliamp for the peels, and 2 minutes 30 seconds at 30 kilovolts and 30 milliamps for the slab specimens. To aid in the interpretation of structural features a few petrographic thin sections were prepared from other oriented silt specimens. 
These were prepared using those procedures outlined on page 52 , or by making and sectioning artificial plugs of coarser material.

\section{Primary Structures}

The Portland Hills Silt is nearly devold of primary depositional features. Most field exposures baring unweathered sections of the silt inevitably reveal a uniform textured, massive deposit. In fact, fewer than five percent of the outcrops examined in the Tualatin Mountains and around the greater Portland-Tualatin Valley region showed any trace of mechanically derived structures.

Even radiographs of a number of sedimentary peels and thin silt slabs taken from the massive silt show no primary sedimentary structures. A11 of the peel radiographs, however, show strong mottling which is generally vertically oriented (Figure 2). Evidently the mottling, as well as most of the other features seen in these radiographs, is due primarily to variations in the peels' thickness. The patterns probably reflect local differences in porosity or moisture content, which in turn has affected the penetration of the impregnatIng cement.

Radiographs of vertical silt slabs taken at each peel site tend to confirm this hypothesis. Figure 3 shows the radiograph of a large "jigsaw" composite slab taken from site \#3. The radiograph reveals several worm or insect tubules, a few rootlets or rootlet holes, and a myriad of tiny, interconnecting joints or fractures. The distinctive mottling, however, is absent.

The large brecciated patch in the upper right corner of the radiograph is believed to be a collapse or inf111 structure, possibly 


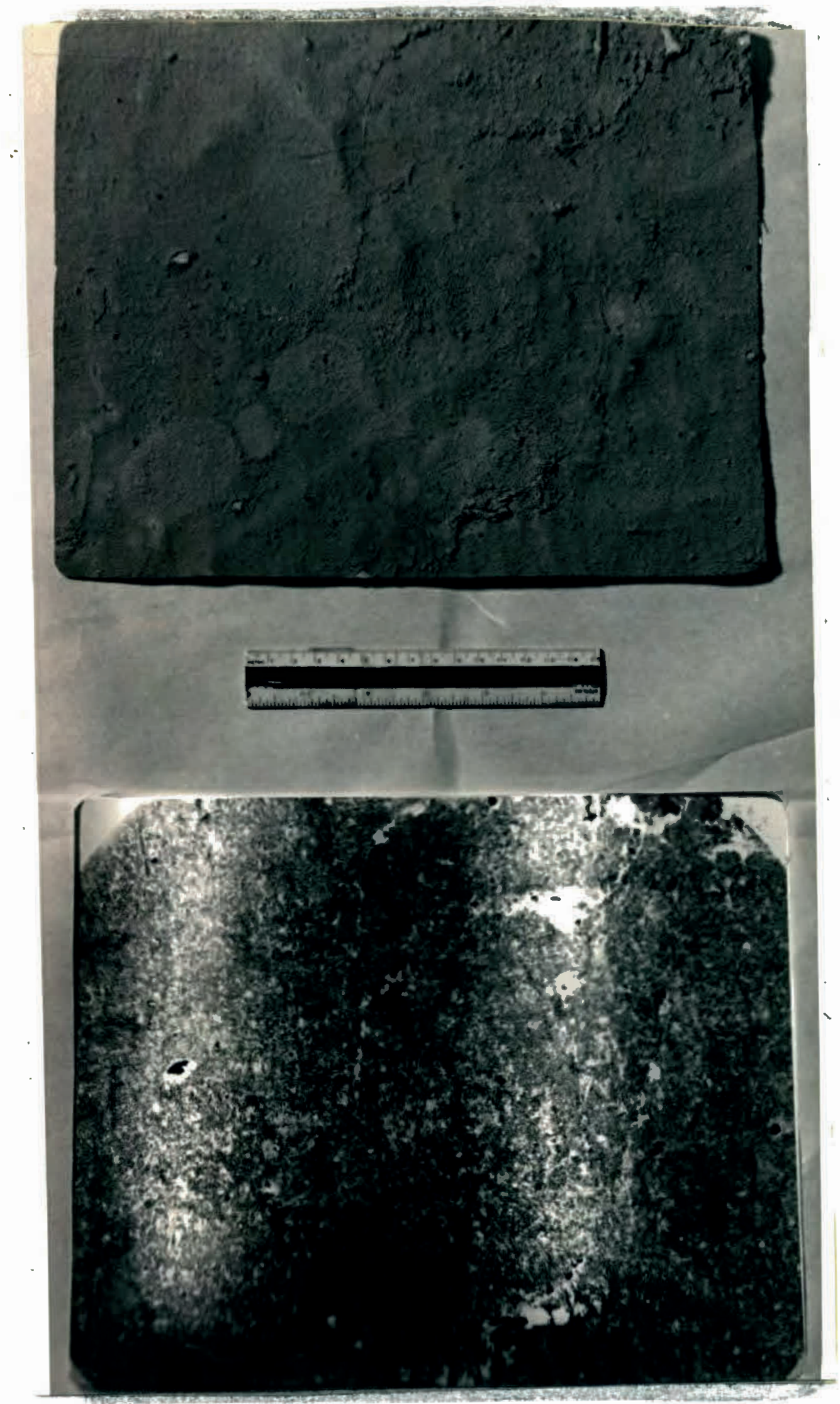

Figure 2. Sedimentary pee1 and corresponding radiograph from site 3. 

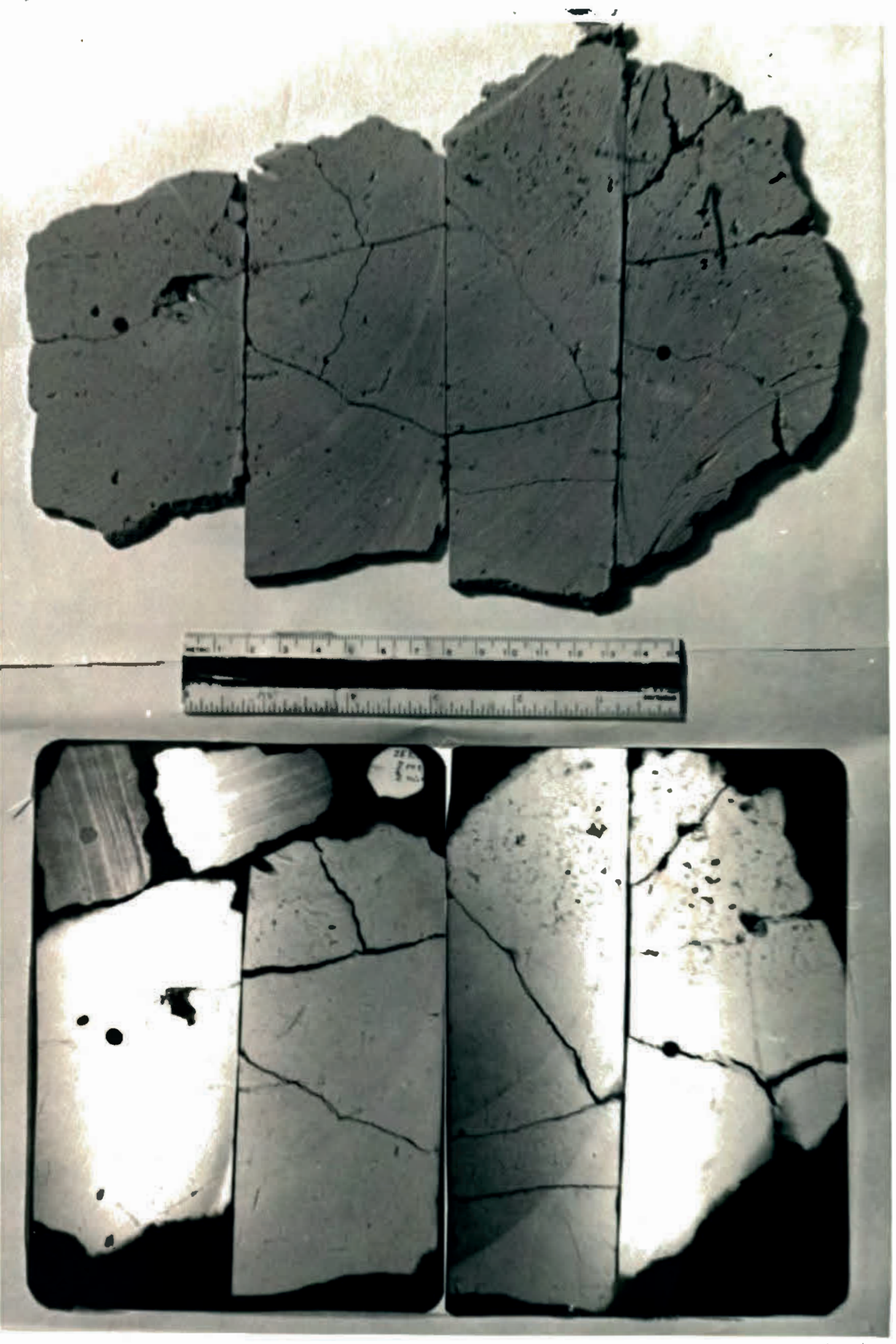

Figure 3. Oriented slab and corresponding radiograph from site 3. 
from the burrow of a small animal. Saw marks also show up clearly in the radiograph, as broad, shadowed arcs. For comparison, a laminated silt slab was $x$-rayed with the massive specimens.

Those primary structures which have been observed in the Portland Hills Silt are of two major types. The more common, and probably more important of these, is large scale bedding or layering of the deposit. Deeper exposures along the Burlington Northern Railroad tracks, sections 30 and 31 , R.1W., T.2N., show typically uniform light yellowishbrown Portland Hills Silt being interrupted at depth by one or two 1.5$2.4 \mathrm{~m}(5-8 \mathrm{ft})$ thick bands of light brown to dark yellowish-orange silt (Figure 4). ${ }^{1}$ The darker, more oxtdized layers are commonly mottled and reticulated throughout, and are suggestive of a weathering horizon. Contacts both above and below the bands may appear smooth and well defined at a distance. But upon closer inspection they display small Irregularties and a distinct gradational character. Normal transition from one zone to the next occurs over a $10-12 \mathrm{~cm}$ vertical interval. The bands tend to conform to the surface topography and form concentric patterns in sections of truncated hills and ridges.

Similar features occur in two deep roadcuts along NW Skyline Blvd. (see page 138), on the crest of the Portland Hills. Here, three darker colored, varlgated silt zones alternate with the lighter, uniform Portland Hills Silt. Sampling and analysis of these profiles showed both zones to be composed of silts having Identical mineral composttion and very similar texture. However, a high percentage of clay, concretionary shot and, often, organic carbon was detected in the

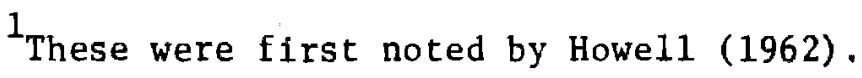




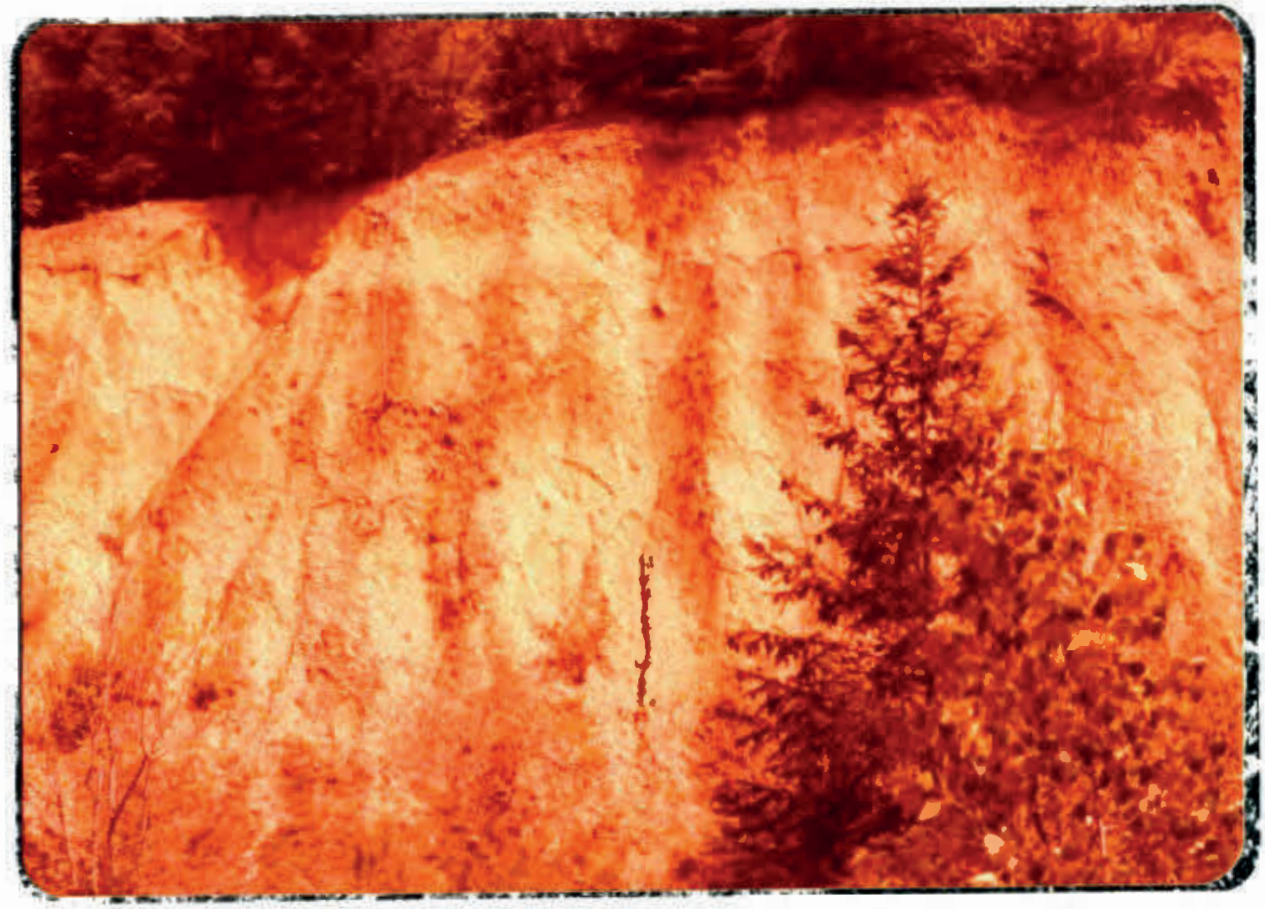

(a)

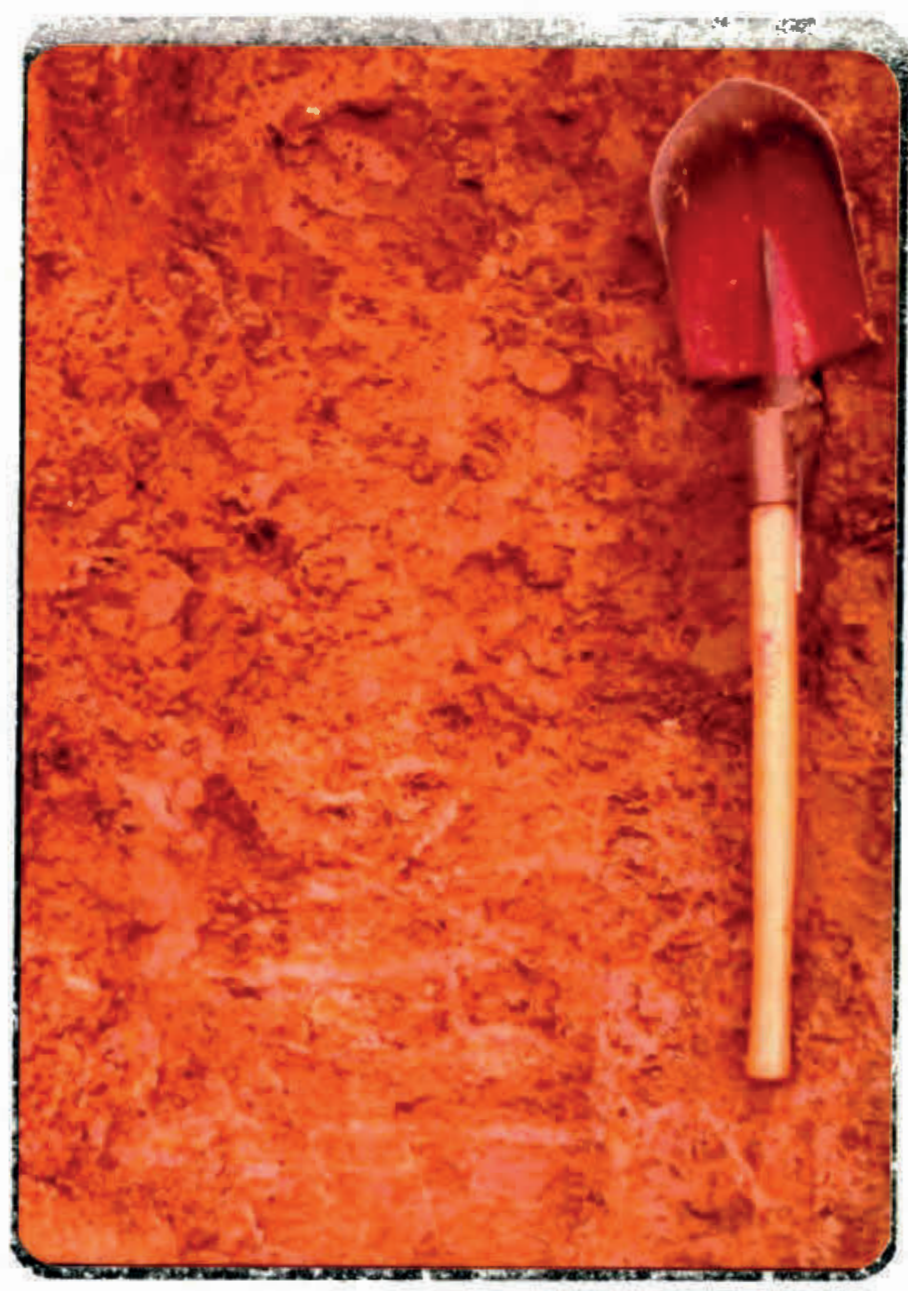

(b)

Figure 4. (a) Burled soll horizon (dark band) In the Portland Hills Silt along the Burlington Northern Rallroad tracks, north of Cornelius Pass; (b) detall of massive Portland Hills S1lt overlying a strong$1 y$ mottled and streaked paleosol. 
more oxidized bands. In addition, the zones commonly displayed vertically oriented, thin gray streaks which are characteristic of soil profiles developed on the silt.

The oxidized layers in the Portland Hills Silt are interpreted for these reasons as buried soil horizons representing at least four major sedimentary cycles. The absence of these horizons in most outcrops is attributed to the exposure's shallow depth and by loss due to erosion. Further description and discussion of these features can be found on page 101.

A second, and rarer, form of stratification in the Portland Hills Silt was evident at two other localities. One is a $4.6 \mathrm{~m}$ (15 ft) deep road cut at approximately $235 \mathrm{~m}(770 \mathrm{ft})$ elevation on the west slope of the Tualatin Mountains, NE $1 / 4$ SE 1/4, sec. 26, T.1N., R.1W., below Reed Drive (Figure 6). This exposure shows about $1.5 \mathrm{~m}(5 \mathrm{ft}$ ) of thin bedded to laminated silt and clayed silt which is overlain by $3 \mathrm{~m}$ (10 $f t$ ) of massive clayey silt. Strata of the basal unit are nearly horizontal in attitude, striking $N 70^{\circ} \mathrm{E}$ and dipping 5 degrees south. They vary in thickness from 0.5 to $18 \mathrm{~cm}$ and, in color, from a medium gray to light reddish-brown. Though smooth and fairly distinct, the contact separating the upper, uniform silt from the lower unit is apparently unconformable. A thin zone of oxidation and weathering tops the lower, bedded unit and a few gray, clay-filled fractures extend downward from the contact, cutting successively older strata.

The lower unit is believed to be reworked Portland Hills Silt deposited probably within a shallow, localized pond. The possibility exists, however, that these strata represent older, Troutdale equivalent 


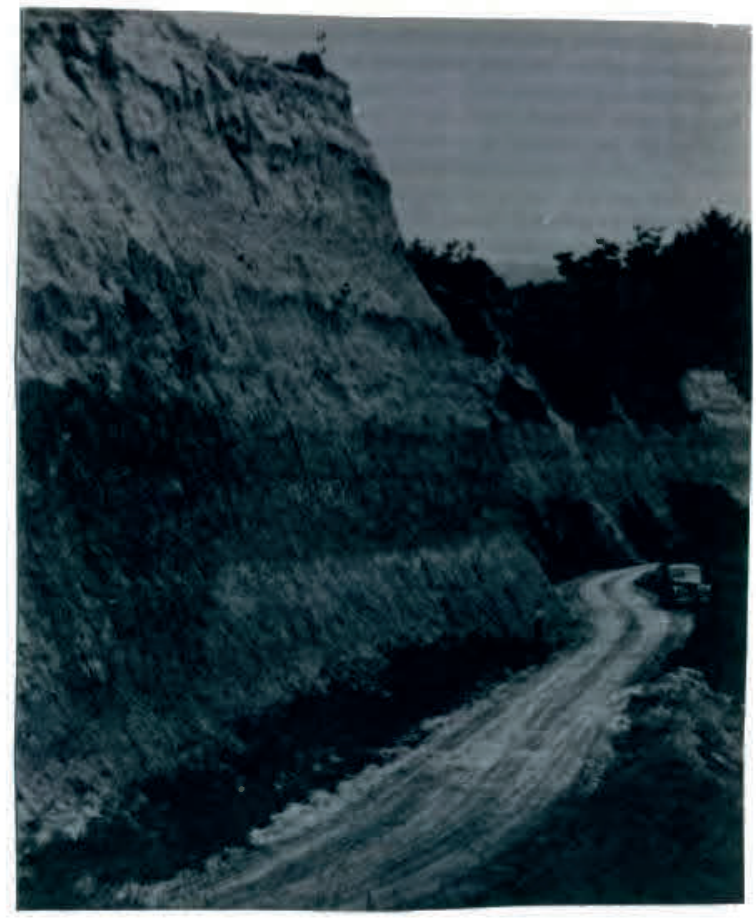

Figure 5. A succession of loess beds on Banks Peninsula, South Island, New Zealand, containing 6 burled solls (from Raeside, 1964).

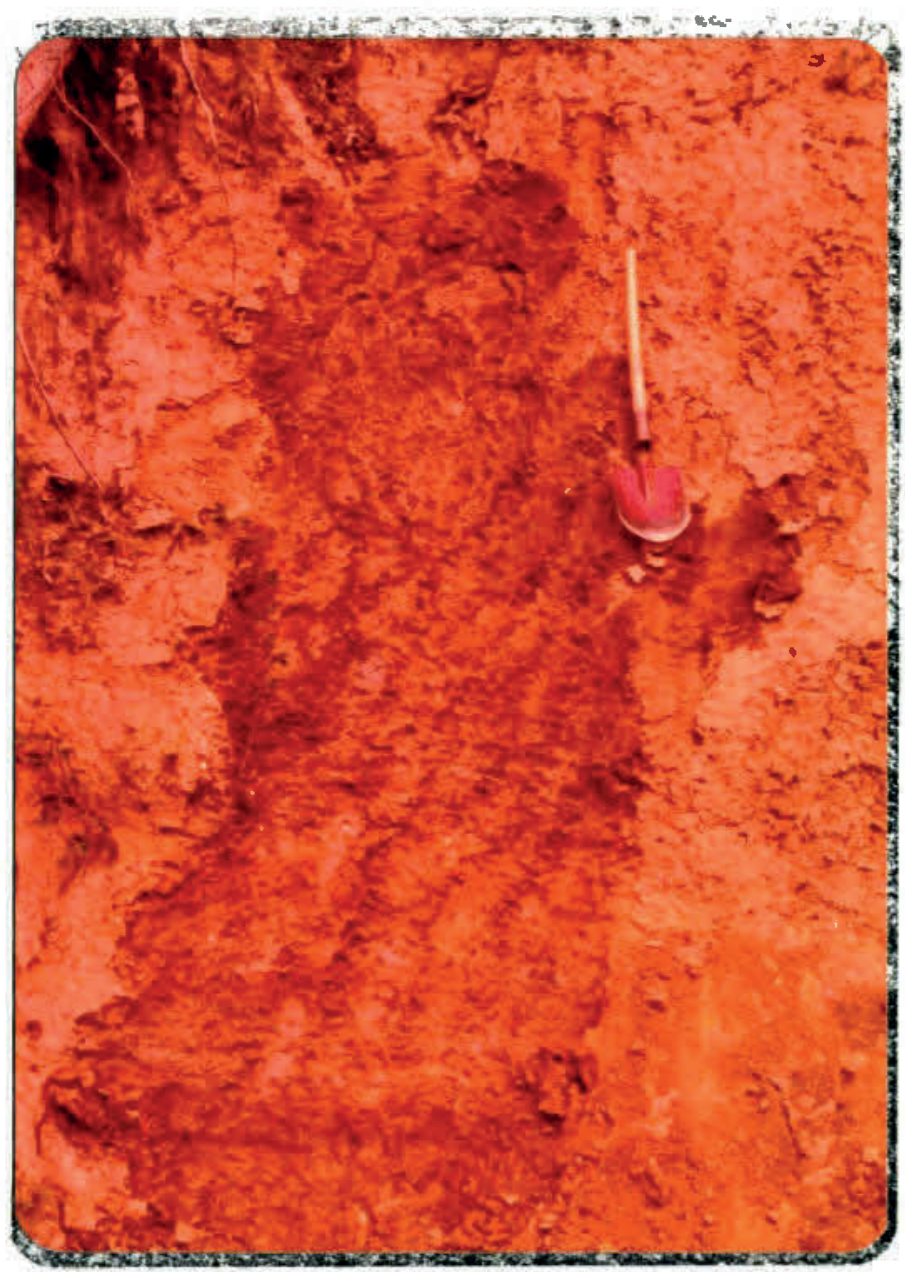

Figure 6. Road cut, NE $\frac{1}{4} \mathrm{SE}^{\frac{1}{4}}$, sec. 26, T.1. N., R.1W., showing massive Portland Hills Silt unconformably overlying bedded and laminated silt and clayey silt. 
sediments, some of which have been mapped a short distance to the northwest. The massive overlying sediments are also interpreted as Portland Hills Silt.

In another road cut along NW Thompson Road, SW $1 / 4 \mathrm{NE} 1 / 4$, sec. 25, T.1N., R.1W., indistinct, 0.5-1.0 mm thick alternating coarseand fine-grained parallel laminae occur in the Portland Hills Silt about one meter below the surface. This stratification parallels the topographic slope and is rather limited in vertical $(15 \mathrm{~cm})$ and lateral $(<100 \mathrm{~cm})$ extent. Uniform silt gradually replaces the laminated material on all sides. These structures are probably the result of localized post- or syndepositional reworking of the silt by slope wash.

\section{Secondary Structures}

A variety of diagenetic or epigenetic structures are found in the Portland Hills Silt. Some are so common and widespread that they are characteristic of the deposit. These include the shot-like concretions and the vertical jointing described by Trimble (1963) and other workers, and which typify the silt's weathering profile.

Concretionary shot is a ubiquitous component of the Portland Hills Silt. It is present in almost all samples irregardless of their location or depth. The weight percent of shot varies from a trace in Eresher silt, to a high of 3.95 percent in the weathered horizons. Theisen (1958, p. 24) found the greatest concentration of these concretions in the $A_{1}$ soil horizon, 0 to $20 \mathrm{~cm}$ below the surface.

The shot normally consists of hard, cemented silt aggregates ranging in size from 0.5 to $10 \mathrm{~mm}$ in diameter (Figure 7). The 


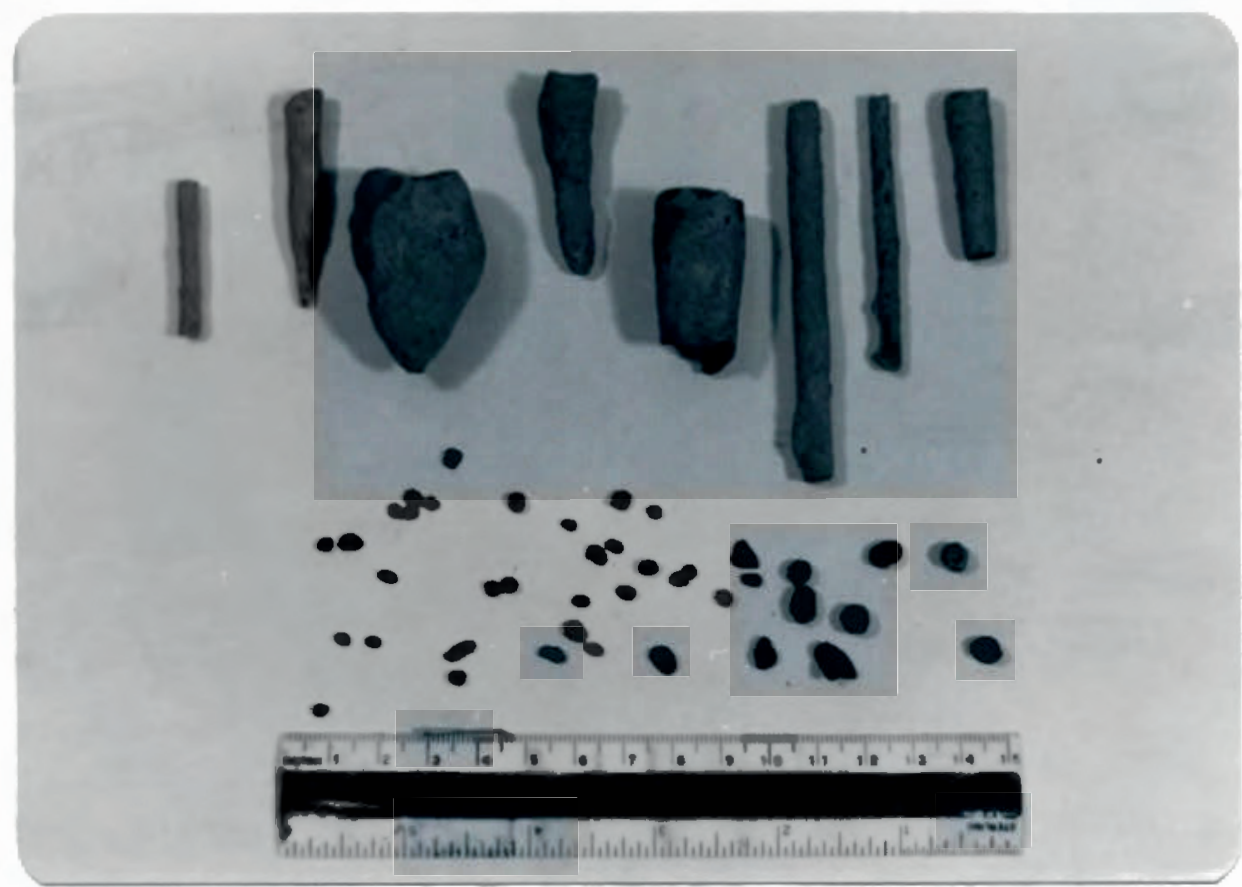

Figure 7. Concretionary root casts ("pipestems") and shot found in the Portland Hills Silt. Note the concentric structure of the root casts. 
aggregates are generally well rounded at any size, but may also be irregular in shape. Colors vary widely from moderate yellow brown to dark yellowish-orange, to reddish-brown to black. In situ, the concretions often appear as dark granules or pebbles of strongly weathered basalt. In such cases careful examination may be required for proper identification. In thin section, however, shot and weathered basalt are easily distinguished (see Figure 8). The angular, fine silt grains which constitute the shot contrast sharply with the distinctive relict texture of even the most highly altered basalt.

Wheeting (1936) studied similar shot solls in western Washington. He found the shot to be richer in iron and aluminum oxides and phosphates, but depleted in silica with respect to the surrounding soll. He believed that the concretions were equivalent to a scattered or disseminated B soil horizon and were formed by "precipitation and dehydration of soluble iron and aluminum compounds around nuclei during the dry summer season." Dehydration of the sesquioxides and phosphates reduced their solubility and converted then to a permanent cement.

A blocky or prismatic jointing pattern is characteristic of the B horizon in soll profiles developed on Portland Hills Silt (Figure 9). The mottled and stained silt of this horfzon is divided into coarse, irregular blocks or near columnar, polygonal shaped prisms. The structure is normally present to depths of 1.25 to $2.0 \mathrm{~m}$ (4-6 ft) but sometimes extends down to $2.5 \mathrm{~m}(8 \mathrm{ft})$. Very pale yellow brown or light gray streaks often delineate the joints. Beginning in the upper part of the $\mathrm{B}$ horizon the $3-5 \mathrm{~cm}$ wide streaks taper downward along the joints. Only a few reach the base of the jointing. Analysis of the 


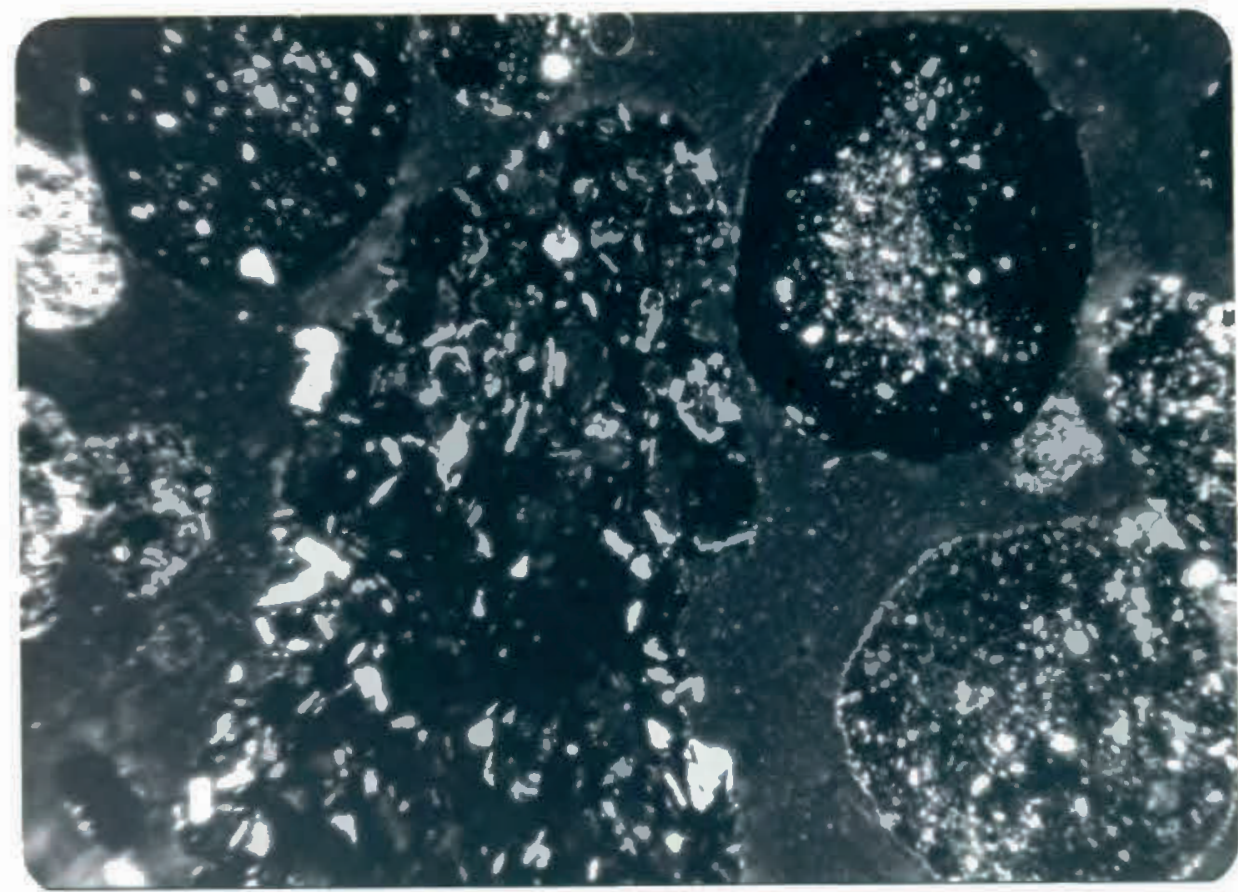

$1 \mathrm{~mm}$

Figure 8. Photomicrograph contrasting the internal fabric and composition of weathered basalt (left) and concretionary shot (right).(X Polars)

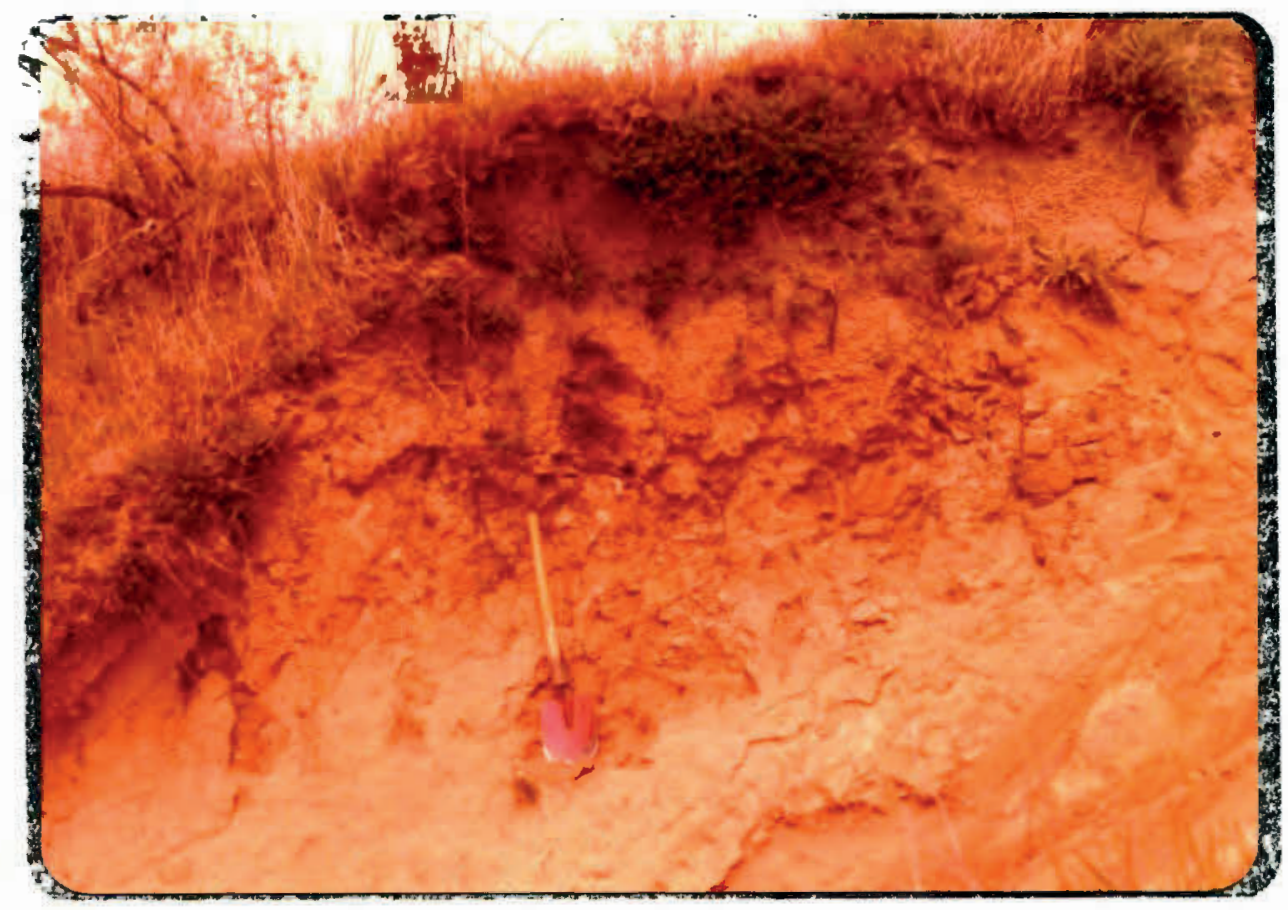

Figure 9. Typical soil profile developed on Portland Hills Silt showing mottling and jointing. 
light colored material shows it to be compositionally similar to unweathered silt except for a high clay content (36\%) and the scarcity of free iron oxides. The streaks probably form through a combination of downward leaching by groundwater and the chemical absorption by the numerous plant roots which invariably crowd the sheet-like joints.

Far less commonplace than the features described above are curiously stained and laminated bands of hydrated iron oxides in the silt. The bands are usually $10-20 \mathrm{~cm}$ in thickness and consist of numerous, fairly distinct $2-4 \mathrm{~mm}$ thick, dark yellowish-orange to rust colored concretionary (?) iron laminae. A succession of orange-red ghost laminae stain the silt beneath and, more rarely, above the ironstone laminae. These become progressively lighter and fade rapidly into uniform silt. The bands occur in and below the soil profile but are almost always associated with local bluish-gray unoxidized zones ${ }^{1}$ in the Portland Hills Silt.

About a half dozen outcrops were found to display the laminated banding. One of these, an old slide scarp on NW Cornell Rd., about $305 \mathrm{~m}(1900 \mathrm{ft})$ east of NW Thompson Rd., NW 1/4 NW 1/4, sec. 31, T.1N., R.1W., is shown in Figures 10-12. The slide scarp reveals several laminated bands wandering erratically across its face, above a gray unoxidized zone. In one place the bands converge to form a single $60 \mathrm{~cm}$ wide layer (see Figure 10). Figures 11 and 12 show the irregularities and contortions of the separated bands, some of which

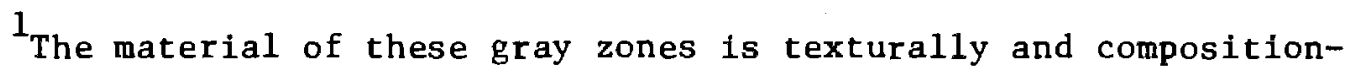
ally identical to the overlying or underlying Portland Hills Silt. Its color is attributed to the deoxidizing processes of gleying (Ruhe, 1969, p. 49). 


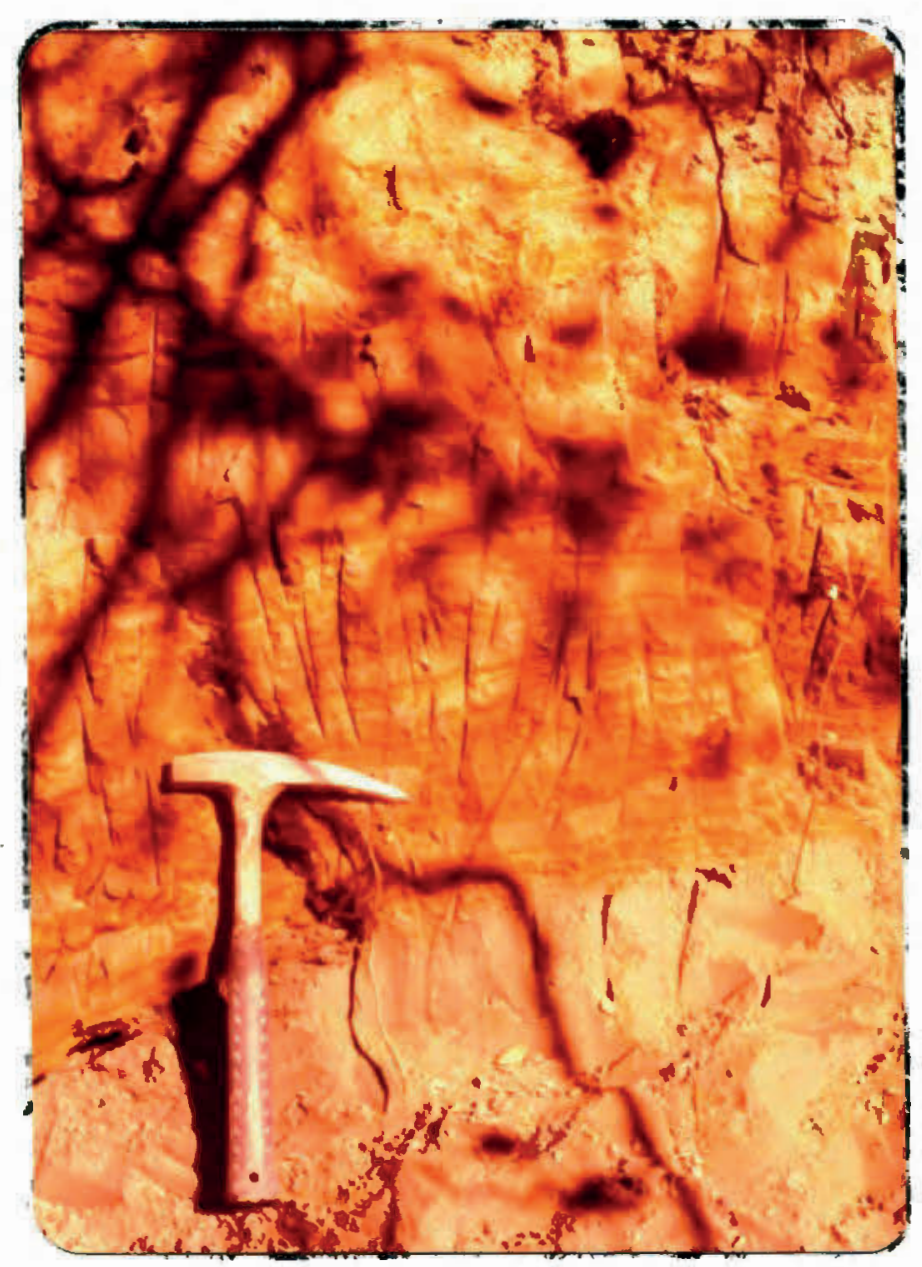

Figure 10. Slide scarp along NW Comell Road, NW'bW R.1W., showing hydrated Iron oxide banding and lamination in the Portland Hills Silt. Note the blue-gray unoxidized zone in the lower part of the photograph. 


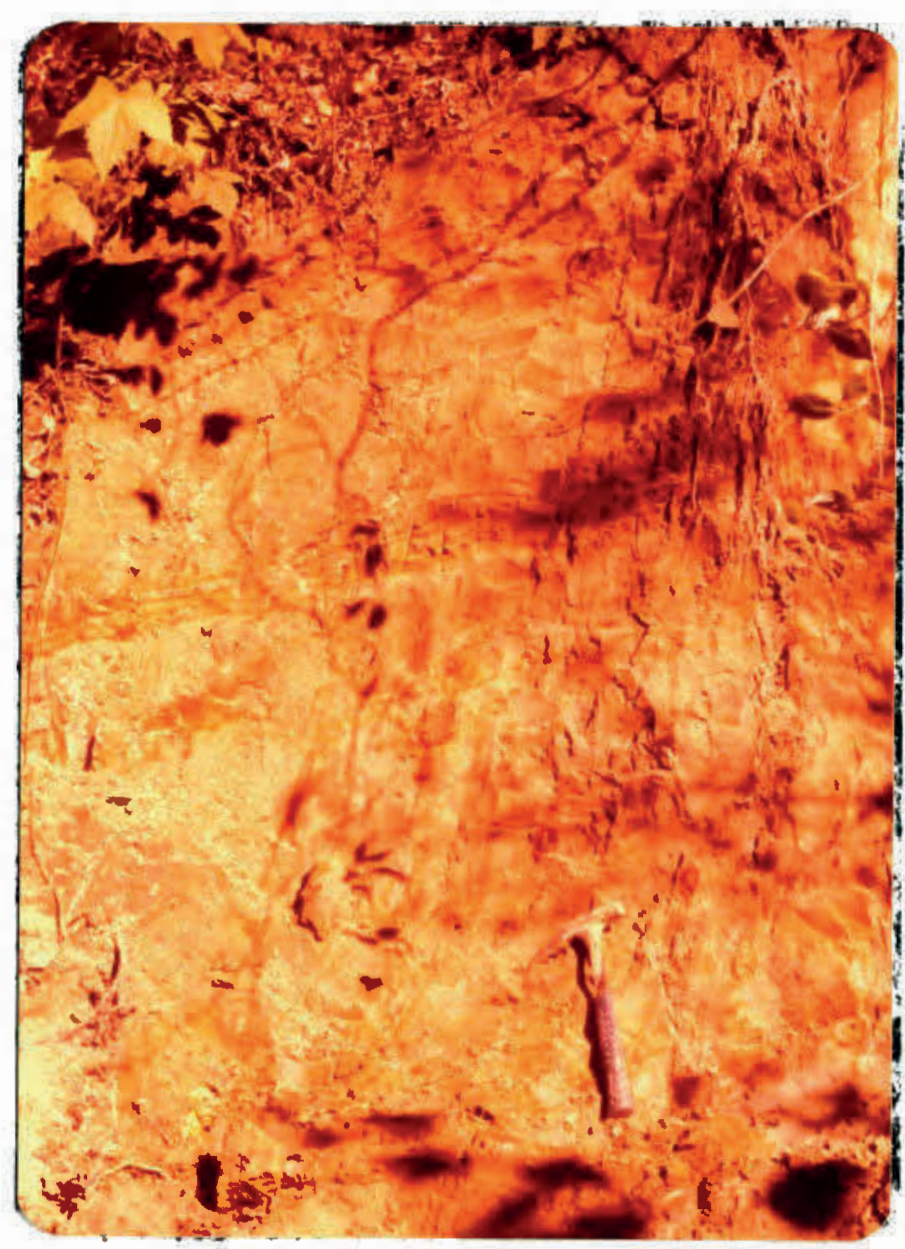

Figure 11. Same Iocality as Figure 10. Note the roundish concretionary structures.

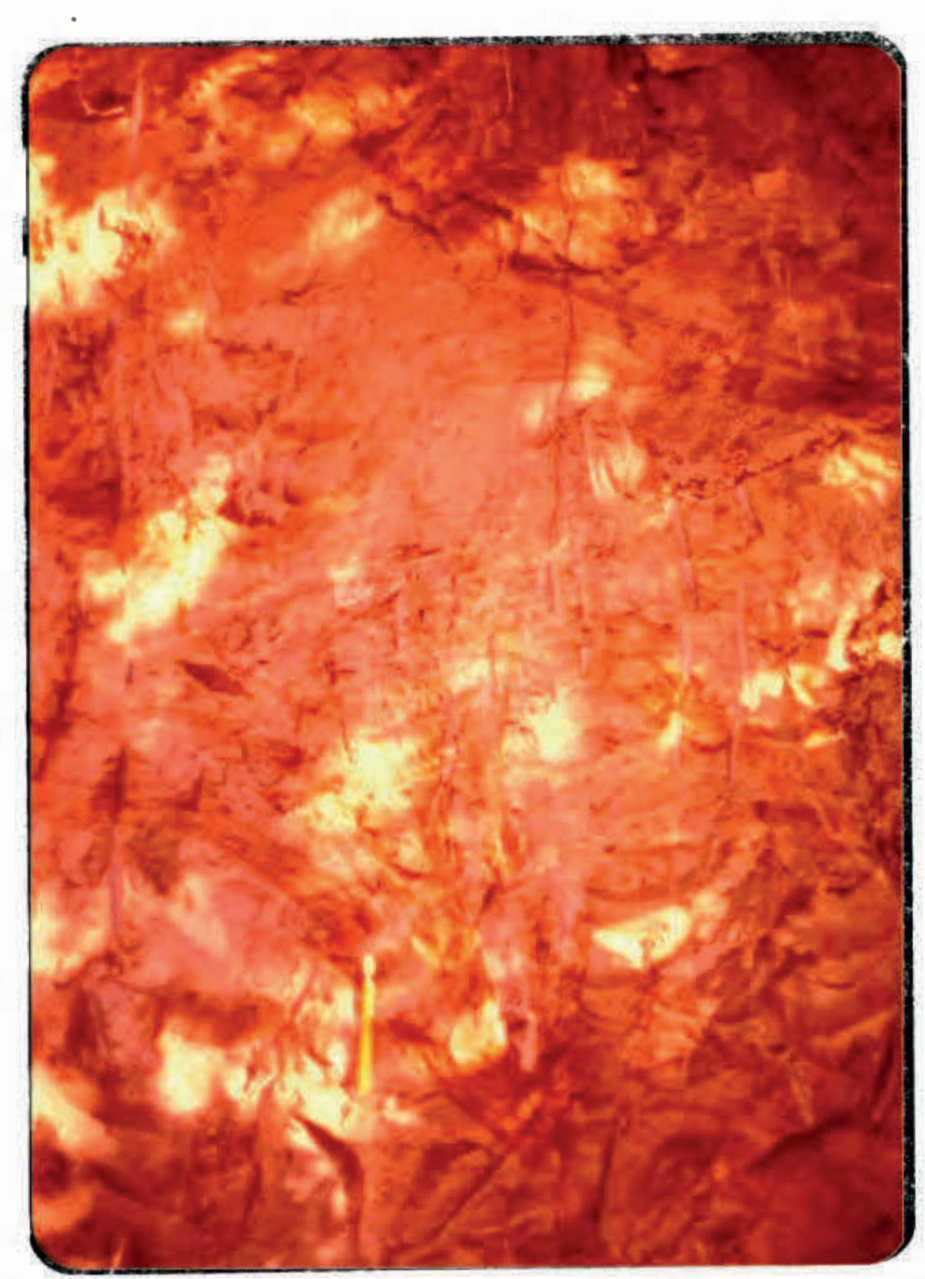

Figure 12. Same locality as Figure 10. The photo shows the local contortions and discontinuities of the iron oxide bands. 
cannot be explained by syndepositional or post depositional folding or slumping. One band curves abruptly downward in Figure 12, apparently responding to a root-filled, gray colored joint. The center-right portion of the same photo shows another band which is truncated while two bands above it remain continuous.

Examination of several thin sections cut normal to the lamination of the iron oxide bands reveals two 1mportant features (see Figure 13): (1) The larger, more stable quartz and feldspar grains are evenly distributed throughout the laminated and non-laminated silt (Smaller grains in the hydrated iron oxide laminae are hidden by those opaque compounds), and (2) The less distinct "ghost" laminae appear only as selectively stained zones in a unfform textured silt.

These data indicate that the band lamination is a secondary feature and is not due to original variations in texture or composition. Perhaps they are the result of local interruptions or variations of the water table, such as those associated with landsliding.

A simflar iron oxide band is present in a road cut on SW Taylors Ferry Rd., NW 1/4 SE 1/4, sec. 29, T.1S., R.1E. (Figure 14). Its smooth horizontal line sets 1t apart from those already described. Howell (1962, p. 19) noted this feature and suggested it marked the unconformity between his "older" and "younger" silt units. It may represent an erosional surface or short depositional break corresponding to one of the paleosols previously described.

Vertically oriented iron oxide tubules or root casts were found at three localities in the Portland Hills Silt. Two of these exposures also displayed laminated Iron oxide bands. 


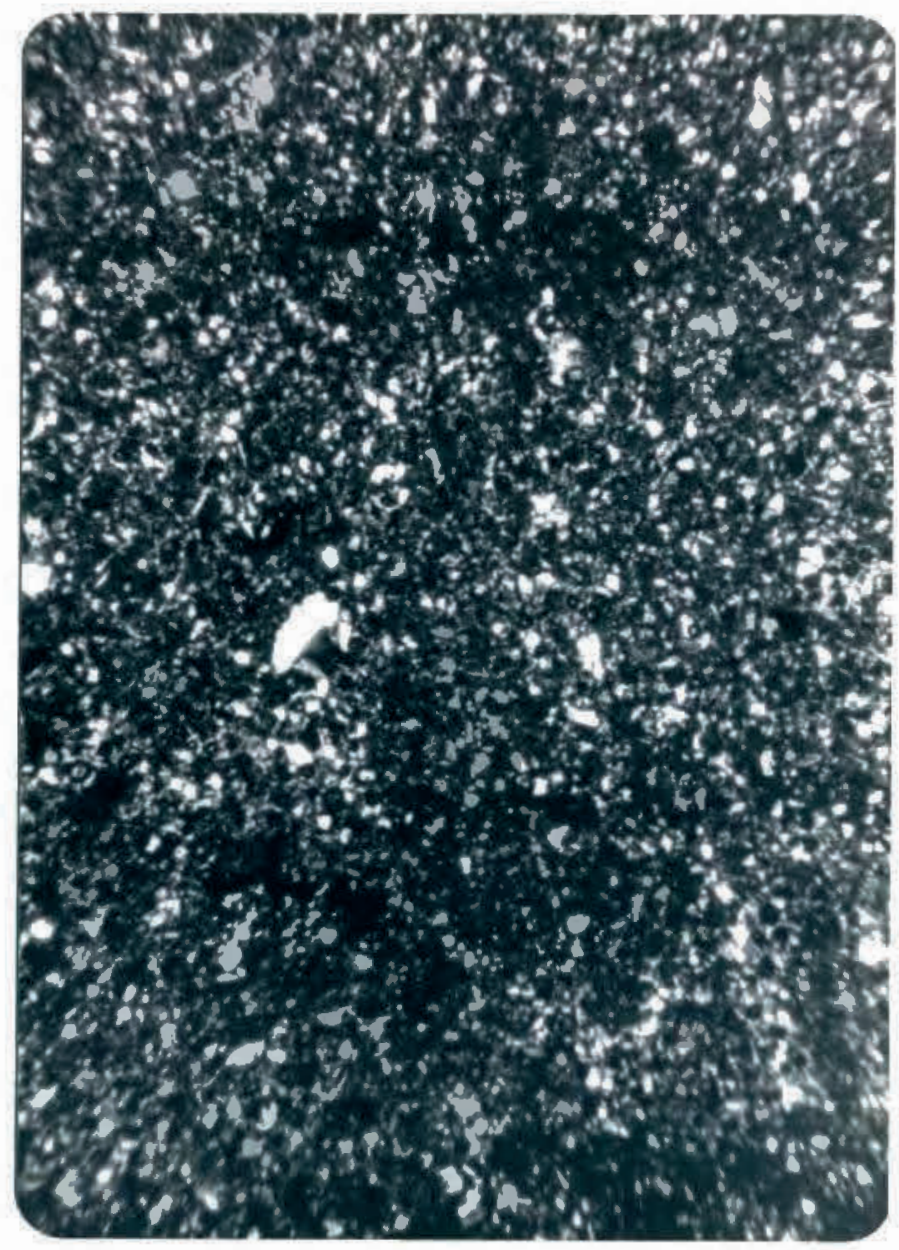

$1 \mathrm{~mm}$

Figure 13. Photomicrograph showing hydrated iron oxide laminations (dark bands) in the Portland Hills Silt. Note the distribution of the larger silt grains across these cemented zones. (X Polars)

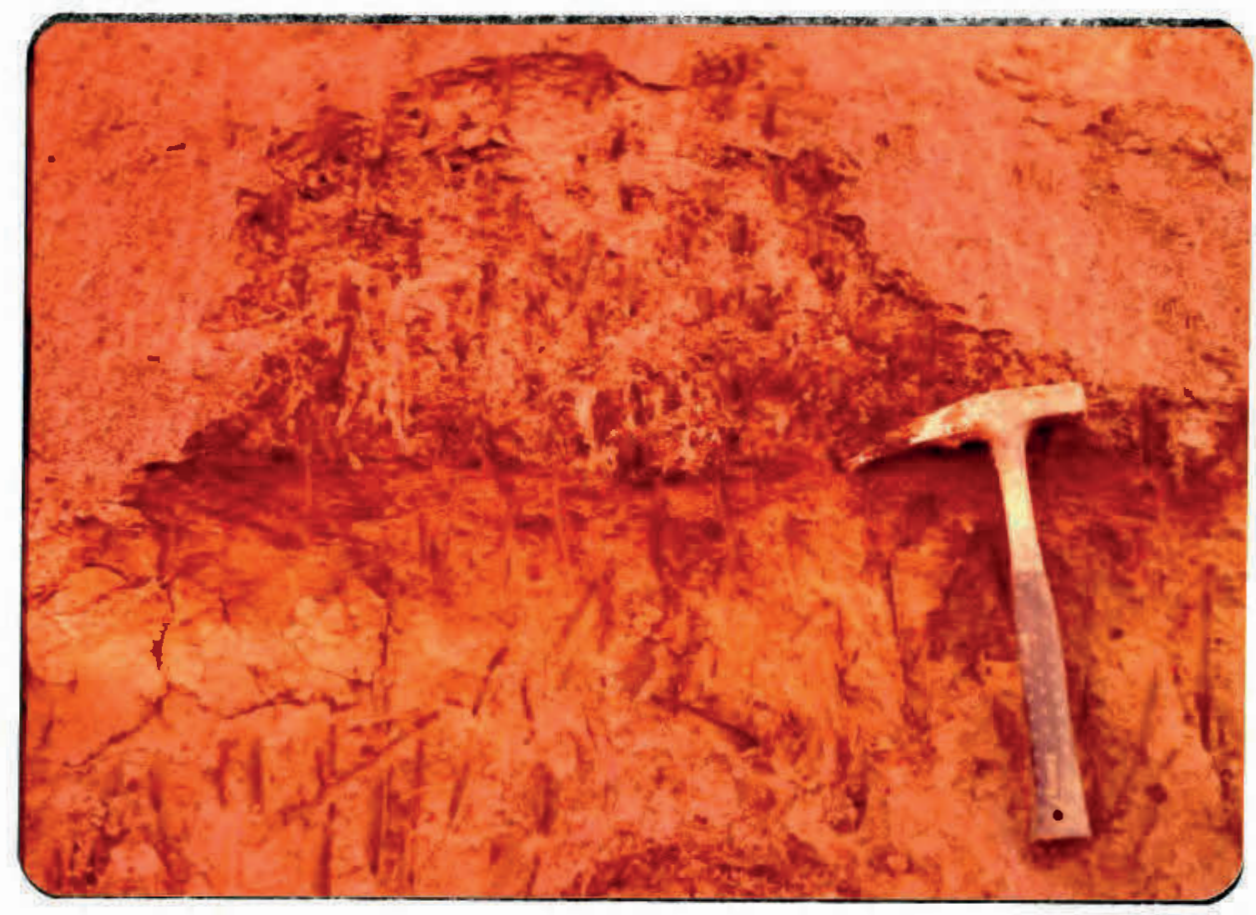

Figure 14. Iron oxide layer and posstble unconformity in a road cut along SW Taylors Ferry Road, $\mathrm{NW}^{\frac{1}{4}} \mathrm{SE}^{\frac{1}{4}}$, sec. 29 , T.1S., R.1E. 
The tubules vary in length from $1-12 \mathrm{~cm}$, and in width from $0.5-$ $3.0 \mathrm{~cm}$ (see Figure 7). Most, however, are slender and fragile. Sections cut across the length of the larger specimens show multicolored bands arranged concentrically about a central 1-2 mm pore. oftentimes a small root still occupies this cavity.

Concretions such as these are commonly found in the deoxidized zones of the mid-western loess deposits, and are known as "pipestems" (Ruhe, 1969, p. 46).

Another secondary structure involving iron oxide segregation was observed in a fresh road excavation along the Baldock Freeway ${ }^{1}$ (Figure 15). About $30 \mathrm{~cm}$ in maximum diameter, the structure showed a central dark gray brown and rust splotched organic or altered rock core, surrounded by relatively unoxidized grayish silt. This, in turn, was bordered by a somewhat diffuse, laminated and stained, iron oxide band.

The structure might be considered a corollary to the largerscaled, laminated banding previously described.

\section{TEXTURE}

Textural data on the Portland Hills Silt is presented under three major headings: Granulometry, fabric, and grain morphology.

\section{Granulometry}

Textural characteristics and areal variations in the Portland Hills Silt were determined from 20 complete granulometric analyses of widespread, uniform depth samples taken throughout the Tualatin

\footnotetext{
$1_{\text {This exposure has since been covered. }}$
} 


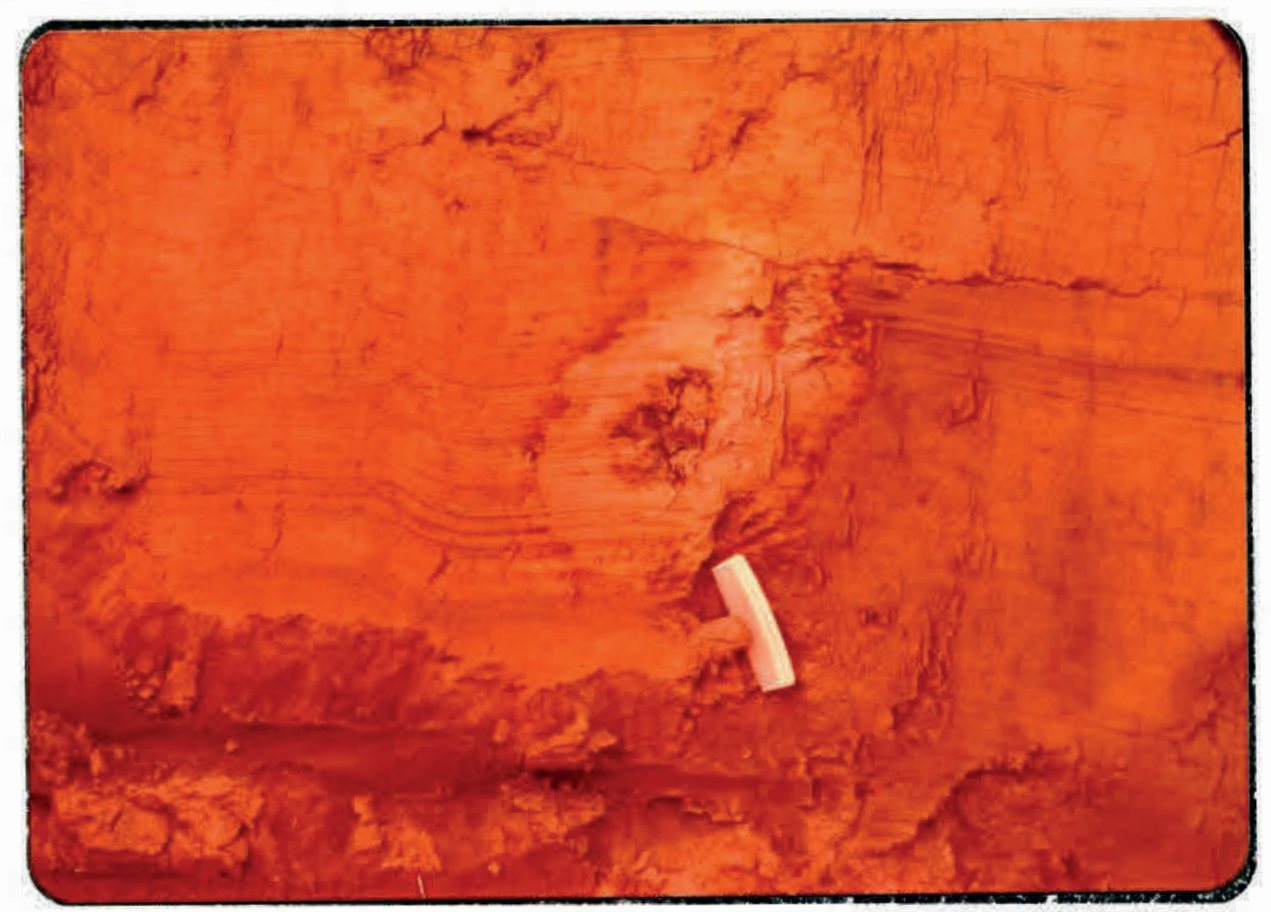

Figure 15. Concretionary structure exposed in Portland Hills Silt along the Baldock Freeway (the road cut has since been covered). 
Mountains. To insure the identity and comparability of these samples, each was chosen on the following basis: (1) Elevation above 122 m (400 ft); (2) structureless character of outcrop; and (3) fresh, unweathered condition of the silt.

To supplement these data, 47 partial granulometric analyses (percent sand, silt and clay only) were performed on other uniform depth samples from the same region. These also include examples from the strongly weathered silts.

Vertical textural variations within the Portland Hills Silt were determined by complete or partial granulometric analysis of 52 variable depth samples from the following principal stratigraphic sections: DAH 76-1, DAH76-2, DAH 76-3, DAH76-4, DAH76-6 and the Skyline School section. Discussions concerning vertical and areal variations of texture, as well as composition, in the Portland Hills Silt are located under Stratigraphy (see page 95).

Textural data and statistics for all Portland Hills Silt samples are listed in Appendix B. Sample locations are noted in Plate 1.

Laboratory Procedures. Standard granulometric techniques were used to obtain the complete and partial grain-size distribution for all samples. The procedures combined sieve analysis for sand-sized material $(>.062 \mathrm{~mm})$ and pipette analysis for silt- $(.062-.004 \mathrm{~mm})$ and clay-sized ( $\varsigma .004 \mathrm{~mm})$ constituents. Particular care was taken to insure routine procedures for all analyses. A flow chart describing these techniques is provided in Appendix A.

Because concretionary shot was found to consist of cemented aggregates of silt, their percentage in the sand fraction was estimated 
and subtracted from the total sample weight.

Table 2 shows the average error for the accumulated percent

values at each phi ${ }^{l}$ interval of the sieve and pipette analyses. The error was determined by performing replicate analyses on three of the original samples. The average error for all phi intervals in the sieve analysis was \pm 0.06 percent, while that for the pipette analysis was \pm 0.95 percent.

The table indicates an expected mean error of \pm 0.02 percent for the sand, \pm 0.89 percent for the silt, and \pm 0.87 percent for the clay content, as determined for any one sample. The actual error for the percentage of sand is probably somewhat larger than indicated, however, because of the error involved in estimating the shot content.

General Characteristics. The grain size distribution in 20 unweathered Portland Hills Silt samples is summarized in Figure 16. The shaded area encloses all of the cumulative grain-size curves for these samples. A typical cumulative curve and its corresponding frequency distribution is also shown.

Inspection of individual cumulative curves show (1) a unimodal distribution for nearly all samples (a few samples displayed a secondary mode of very fine silt or clay which was probably due to analytical error), and (2) a very narrow modal range between 4.3 and $4.8 \mathrm{phi}$ in the coarse silt fraction. The data illustrates a remarkable textural consistency for the Portland Hills Silt throughout the Tualatin Mountains, a characteristic of which it has long been accredited.

Table 3 lists the mean, standard deviation and range of various

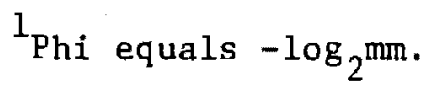


TABLE 2

MEAN ERROR FOR CUMULATIVE PERCENT VALUES

\begin{tabular}{|c|c|c|}
\hline \multicolumn{2}{|c|}{ CUMULATIVE } & $\begin{array}{l}\text { MEAN } \\
\text { ERROR }\end{array}$ \\
\hline \multirow{5}{*}{ 点 } & 0 & $\pm 0.04 \%$ \\
\hline & 1 & $\pm 0.01 \%$ \\
\hline & 2 & $\pm 0.01 \%$ \\
\hline & 3 & $\pm 0.02 \%$ \\
\hline & 3.5 & $\pm 0.08 \%$ \\
\hline & 4 & $\pm 0.20 \%$ \\
\hline & 4.5 & $\pm 0.27 \%$ \\
\hline & 5 & $\pm 1.15 \%$ \\
\hline 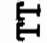 & 5.5 & $\pm 1.57 \%$ \\
\hline 琶 & 6 & $\pm 2.30 \%$ \\
\hline - & 7 & $\pm 1.00 \%$ \\
\hline & 8 & $\pm 0.87 \%$ \\
\hline & 9 & $\pm 0.65 \%$ \\
\hline
\end{tabular}




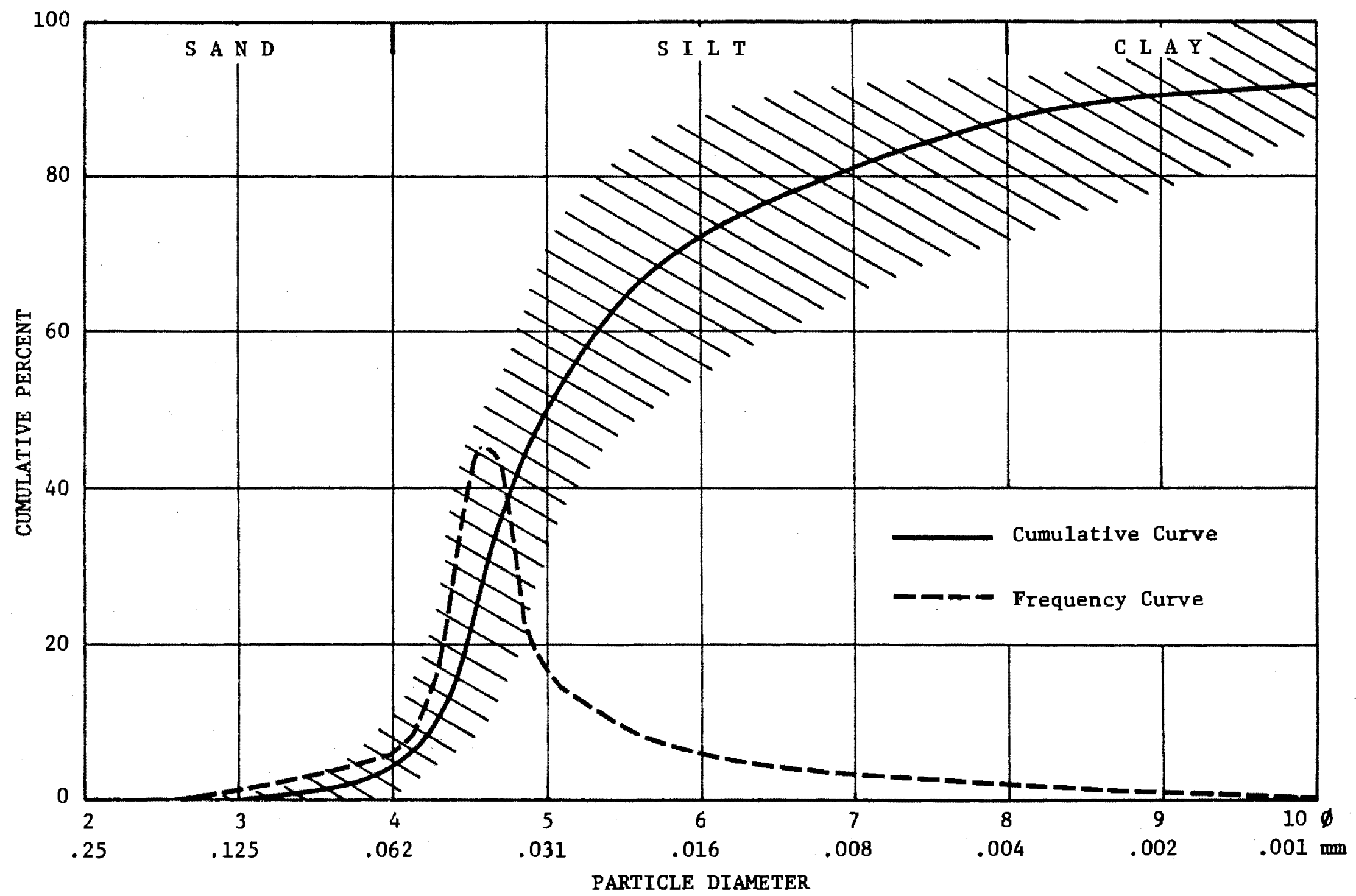

Figure 16. Range of cumulative frequency curves of 20 unweathered Portland Hills Silt samples. Also shown is a typical cumulative frequency curve and its corresponding frequency distribution (sample 76-15). 
TABLE 3

TEXTURAL DATA FROM 20 WIDESPREAD SAMPLES TAKEN AT UNIFORM DEPTH, FROM UNWEATHERED PORTLAND HILLS SILT

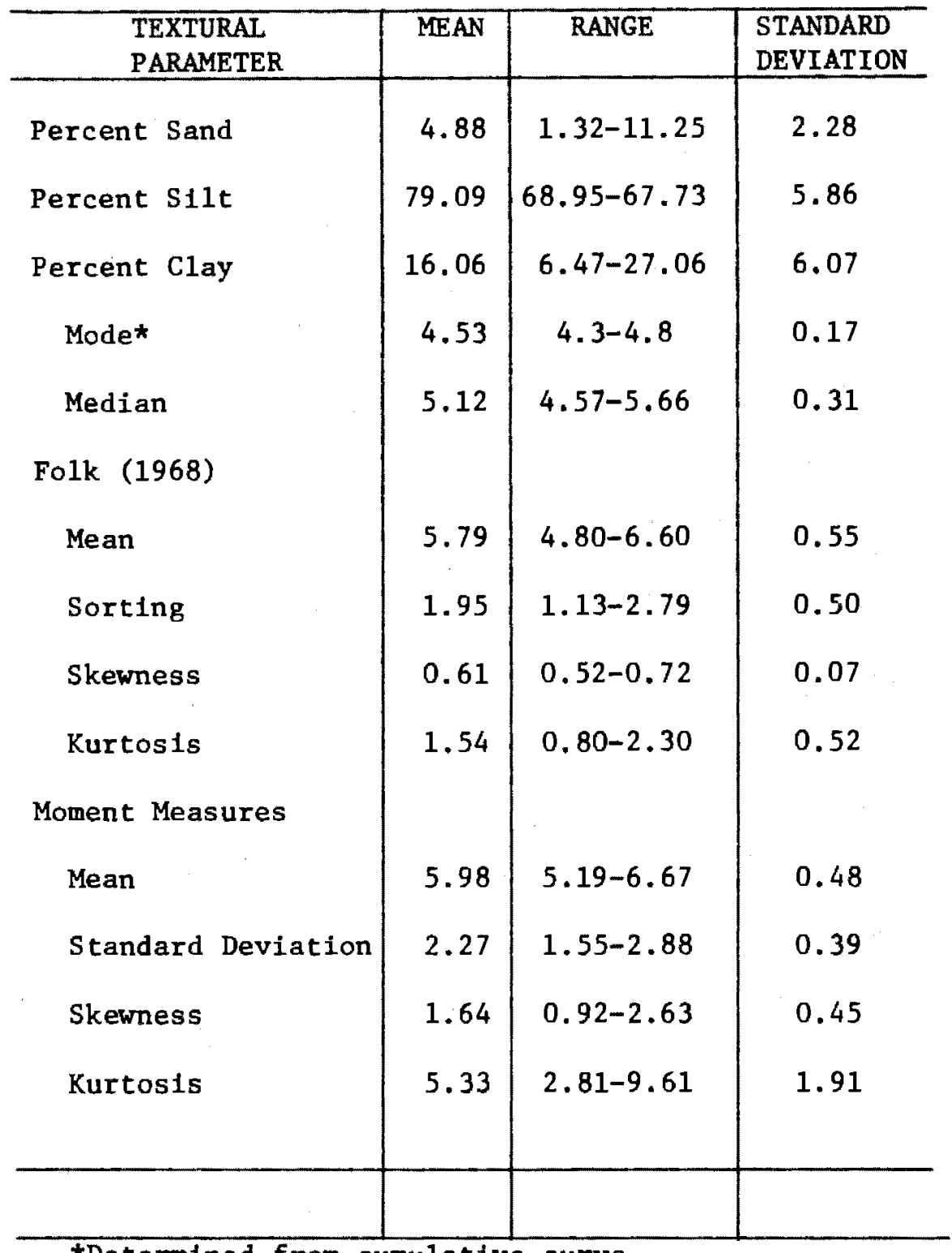

*Determined from cumulative curve. 
textural characteristics and statistics of the 20 samples described above. Folk and Ward textural statistics (Folk, 1968, p. 46-48) indicate that the Portland Hills Silt is (1) poorly sorted to very poorly sorted, (2) strongly fine skewed, and (3) very leptokurtic to extremely leptokurtic. The marked peakedness described by (3) above is exemplified by the frequency distribution curve in Figure 16.

The mean, standard deviation and range of the percentages of sand, silt and clay in 67 Portland Hills Silt samples are listed in Table 4. The samples include those 20 listed in Table 3, and 47 additional uniform depth samples from scattered locations about the Tualatin Mountains. Note that the average percent and the standard deviation of sand, silt and clay for the strictly unweathered samples in Table 3 and those in Table 4, which incorporated some weathered silts, vary only slightly. The major distinction between the two is a 2.5 percent increase for the mean clay content in the larger sample population.

Table 4 shows that silt-sized particles constitute the vast majority of grains in the Portland Hills Silt: the average silt content being greater than 75 percent.

Statistically, 95 percent of all Portland Hills Silt samples will fall within \pm 2 standard deviations of the mean sand, silt and clay percentages (Mendenhall, 1971, p. 183). 1 The relatively tiny "size range" which results (Figure 17) confirms the uniformity of the deposit. Outsized Clasts. A considerable effort was made during the field

$l_{\text {Because the samples were not collected at random, this is not }}$ strictly true. However, the large number and widespread distribution of the samples should give a very close approximation. 
TABLE 4

AVERAGE TEXTURE OF 67 WIDESPREAD

UNIFORM DEPTH PORTLAND

HILLS SILT SAMPLES*

\begin{tabular}{l|c|c|c}
\hline & MEAN & RANGE & $\begin{array}{c}\text { STANDARD } \\
\text { DEVIATION }\end{array}$ \\
Sand & 4.90 & $1.40-14.2$ & 3.0 \\
S11t & 77.2 & $56.9-87.7$ & 6.0 \\
Clay & 18.9 & $6.47-39.9$ & 6.3 \\
\hline & & & \\
\hline \multicolumn{2}{|c|}{ *Includes a11 samples from Table 3. }
\end{tabular}

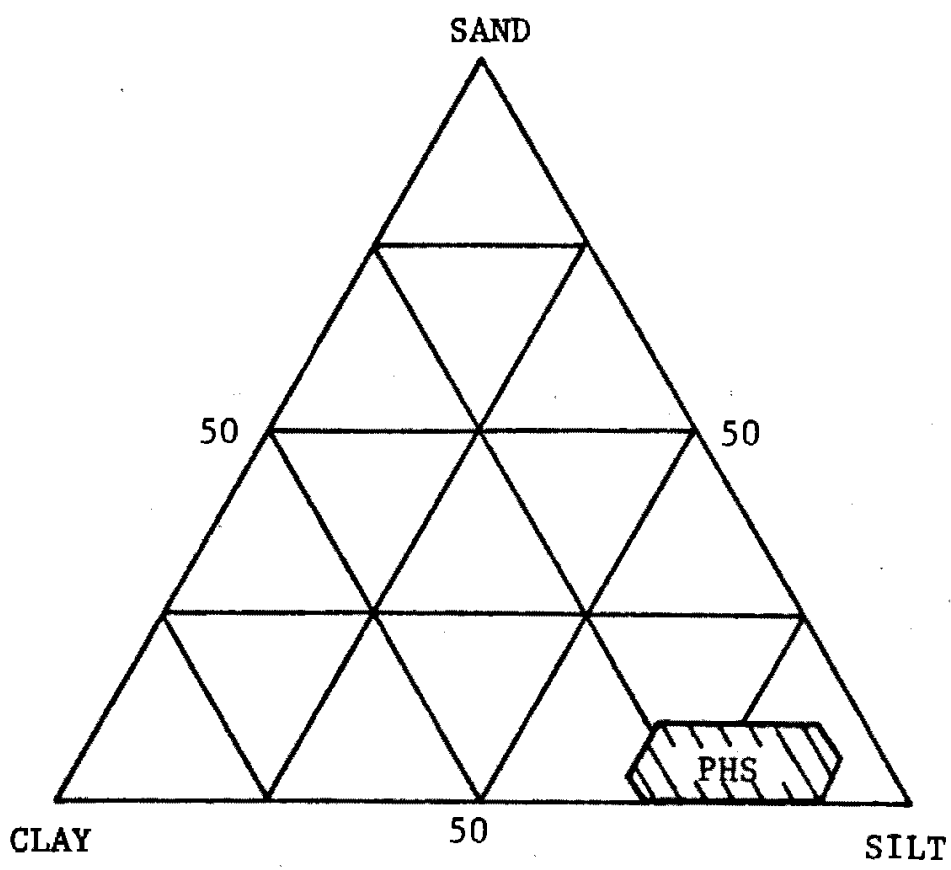

F1gure 17. Textural boundaries enclosing 95 percent of al1 Portland Hills Silt samples. Sand, silt and clay ranges were derived by adding and subtracting twice the standard deviation from the mean of each. 
examination of each outcrop to detect any outsized clasts which might be incorporated in the Portland Hills Silt. Other than larger (2-10 mm) concretionary aggregates or shot, coarser clasts of gravel or rubble in the Portland Hills Silt are rare. Scattered pebble-sized or larger basalt fragments are sometimes found near the base of silt sections which overlie Boring Lava. One such locality is near Elk Point, NW 1/4 NE 1/4, sec. 62, T.1N., R.1W. However, at a deep road cut along NW Germantown Rd, SW 1/4 NW 1/4, sec. 46, T.IN., R.1W., an altered, $3 \mathrm{~cm}$ vesicular basalt pebble was discovered on top of what may be a buried soil profile, $3 \mathrm{~m}$ below the surface.

Pebbles of quartzite and siliceous rock types are present in what is either colluvial or primary Portland Hills Silt along NW Leif Erickson Dr., N 1/2, sec. 57, T.1N., R.1W. The deposit is underlain there and upslope by Troutdale gravels of the same composition. No pebbles of any kind were found in place along the crest of the Tualatin Mountains. Though, in a few exposures, colluvial silt had been contaminated with mafic, siliceous or quartzite pebbles derived from the subgrade of adjacent roadways.

This investigator is in complete agreement with Trimble (1963, p. 51) concerning the manner and origin of pebbles in the Portland Hills Silt. Outsized clasts found in the deposit are believed to represent only extraneous material derived by colluvial or alluvial processes. Contamination most likely occurs during the accumulation of the silt (Trimble, 1963, p. 51) or as the result of post depositional reworking. 
Fabric

Evaluation of the fabric and framework geometry of the Portland Hills Silt involved thin section studies of three widespread, oriented silt samples. The principal objective of the study was to determine the spacial arrangement and preferred orientation, if any, of the various textural components of the silt, especially in relation to paleocurrent directions. The locations of those samples examined (76-23, 76-85, DAH 76-6b) are shown in Plate 1 .

Laboratory Procedures. Thin section preparation for fabric analysis involved the following procedures: (1) Sectioning of the oriented samples into two vertically oriented thin section billets, one east-west and another north-south; (2) proper labeling and polishing of the billets (polishing was done very carefully on a dry, well-worn lap glass without abrasives); (3) billet impregnation (6:1 glyptol:acetone mix); (4) repolishing and mounting; and (5) thin sectioning and cover glass mounting.

Mica was chosen over quartz or feldspar for the determination of preferred fabric orientation because its near two-dimensional form would (1) resist rolling or disruption during thin section preparation, and (2) allow rapid appraisal of grain orientation during qualitative measurements.

The inclination of all mica plates falling beneath the crosshairs during equally spaced, thin section traverses were measured and recorded. The mean inclination and standard deviation for each eastwest and north-south section was then calculated (Carver, 1971, p. 320331). In the event that the preferred orientation was not significant 
at the 5 percent level, further measurements were obtained to confirm the existence of very weak, preferred orientation. Finally, the mean inclinations of each sample pair were resolved steriographically to obtain the preferred 3-dimensional orientation of the mica plates. Fabric Character and Mica Orientation. The photomicrograph in Figure 18 shows the characteristic fabric relationships amongst the variously sized textural components of the Portland Hills Silt. The pattern indicates an apparently random distribution of all particles in the silt, larger grains being nearly evenly distributed throughout a finer, silt and clay matrix. Further, elongated grains have no obvious preferred orientation. In fact, they appear randomly oriented in most views.

The rose diagrams in Figure 19 show the mica inclinations in the east-west and north-south thin sections of three Portland Hills Silt samples. Also given is the number of measurements, the mean inclination and the standard deviation of the mica in each section. The preferred mica orientation in each sample was ascertained using these values and is listed along with the present slope aspect at each sample site.

The diagrams illustrate a distinct horizontal or near horizontal preference for the mica plates in all of the sample sections. All sections showed a strong preferred inclination for the mica except DAH76-6b N-S and 76-85 N-S, which tend to be bimodal.

The 3-dimensional orientation of mica in the samples are not at all related, either to one another or, apparently, to slope aspect. This might suggest sediment deposition by multiple direction paleocurrents (Pettijohn, 1975, p. 63). However, factors other than current 


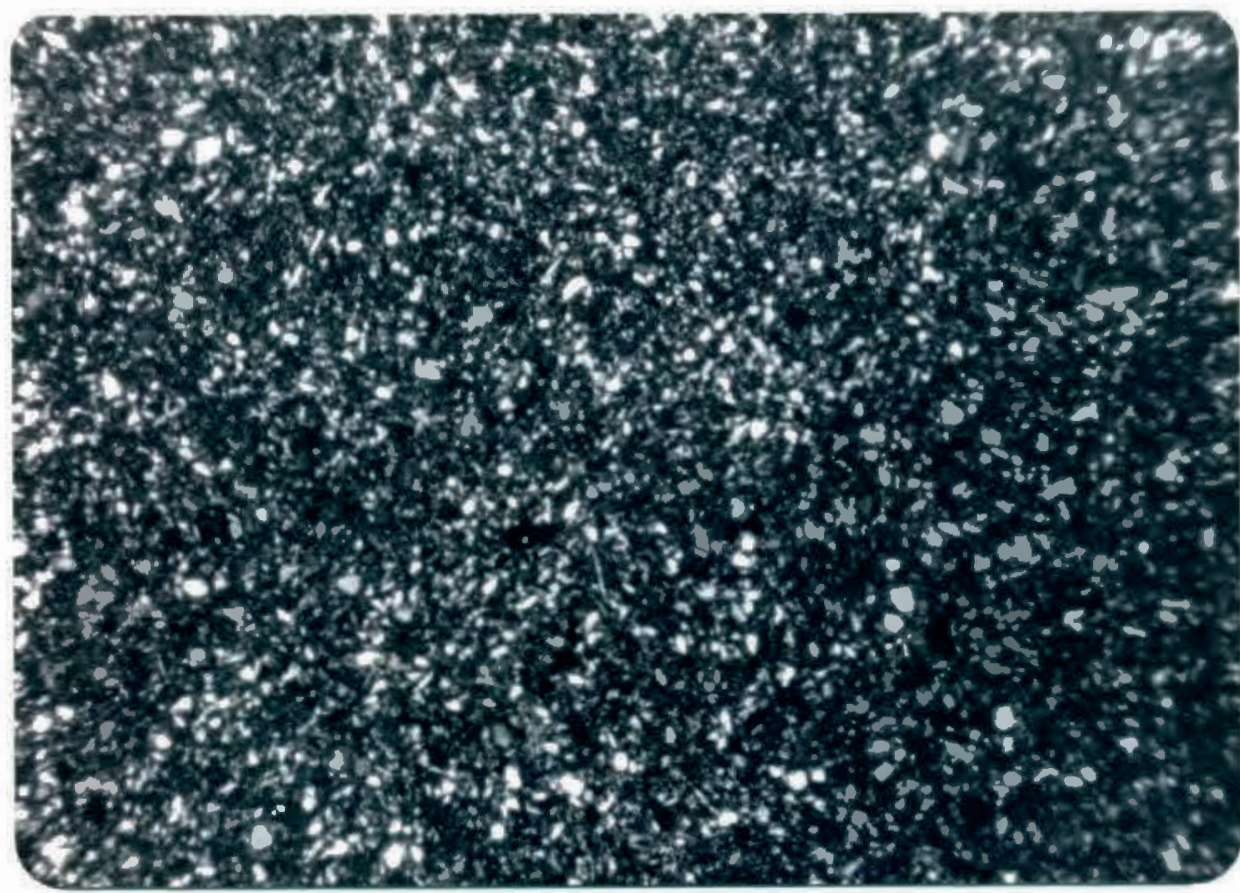

$1 \mathrm{~mm}$

F1gure 18. Photomicrograph showing the fabric of the Portland Hills Silt. Note the poor sorting and random distribution and orientation of the silt particles. (X Polars) 
F1gure 19. Mica Orientation 1n three wideapread Portland H11ls s1.t.t samples.

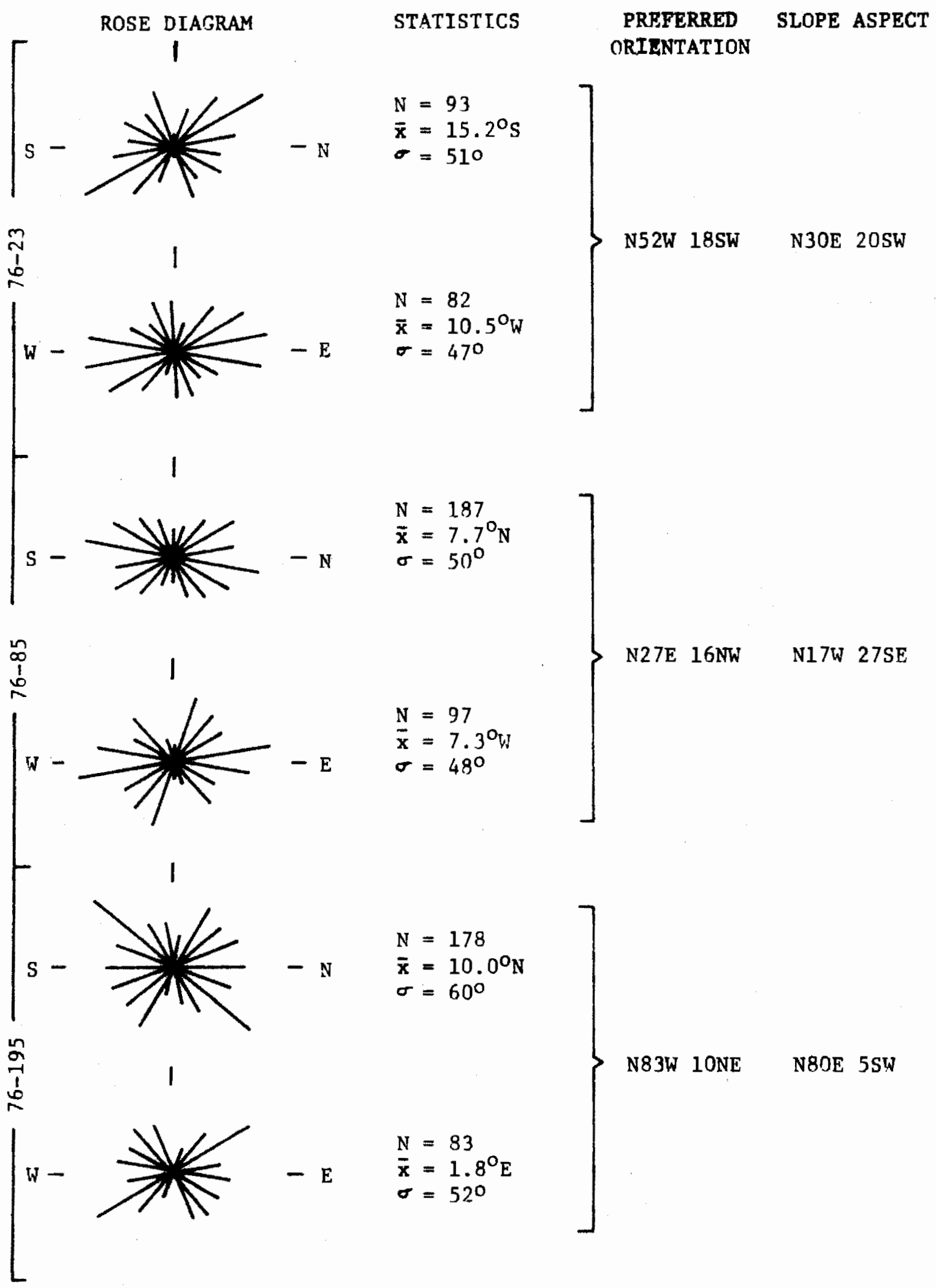


direction may have influenced grain orientation in these samples. The more Important of these include slope aspect of the deposition site and such secondary effects as structural deformation (tectonic and gravity flow) and compaction.

Thus, for a meaningful determination of the direction of paleocurrents which were active during deposition of the Portland Hills Silt, additional data is necessary. More information is needed to evaluate both the preferred grain orfentation in the formation and those factors which might significantly affect that orientation.

\section{Particle Morphology}

Morphological characteristics of 1ndividual mineral constituents of the Portland Hills Silt are summarlzed 1n Tables 6 and 8 (see pages 65 and 69 , Composition). The data show that the Portland Hills silt is essentially composed of sub-angular mineral grains of moderate sphericity. Rounding varies between 0.2 and 0.4 on Power's scale (1953, p. 117), with 0.3 being most frequent. Similarly, the sphericity ranges from about 0.5 to 0.7 , with a mode of 0.6 on the sphericity scale devised by Krumbein and Sloss (1951, p. 111). A higher degree of rounding $(0.6)$ is displayed by rock fragments and a few quartz grains In the coarser sand fraction of the deposit. Muscovite and leached blotite, however, occur as rounded platelets throughout the1r size distribution.

Surface textures amongst the mineral grains differ considerably. Those minerals which commonly show signs of corrosion or etching are plagloclase, potassium feldspar, augite and the epidote group. 
Ultra-stable or stable minerals such as zircon, tourmaline and apatite are generally rounded or subrounded and worn to a polish. Fresh, or nearly fresh, appearing cleavage or fracture surfaces are typical of quartz, hornblende, kyanite and garnet minerals.

The surface textures of $0.5-1.5 \mathrm{~mm}$ sized quartz grains in Portland Hills Silt were studied in detall, with the ald of a Tektronix prototype scanning electron microscope. All specimens were prepared using the procedures outlined by Carver (1971, p. 152). Photo micrographs were obtained using Polaroid photography.

Electron microscopy of Portland Hills Silt grains reveal surface textures which are characteristic of glacial or glacial-fluvial enviroments. The more indicative of these features (Carver, 1971, p. 161), angularity, extreme relief and a large variation in size of conchoidial breakage-patterns, are shown by the Portland Hills Silt grains in Figure 20. Other textures associated with glacial processes are shown in Figure 21. These include the semiparallel steps (s), arcsinaped steps (c), and the Imbricated breakage blocks (b) described by Krinsley and Donahue (1968).

Loess particles studied by Cegla and others (1971) and Warnke (1971) reveal surface textures very much like those of the Portland Hills Silt grains. Moreover, tiny adhering particles, such as those seen on the grain in Figure 21, are considered typical of loess grains.

Note the textural similarity between the Portland Hills Silt grains (Figure 20) and those of the Columbia River sediments (Reed Island) ${ }^{1}$ in Figure 22 .

${ }^{1}$ Collected by Robert 0 . Van Atta. 


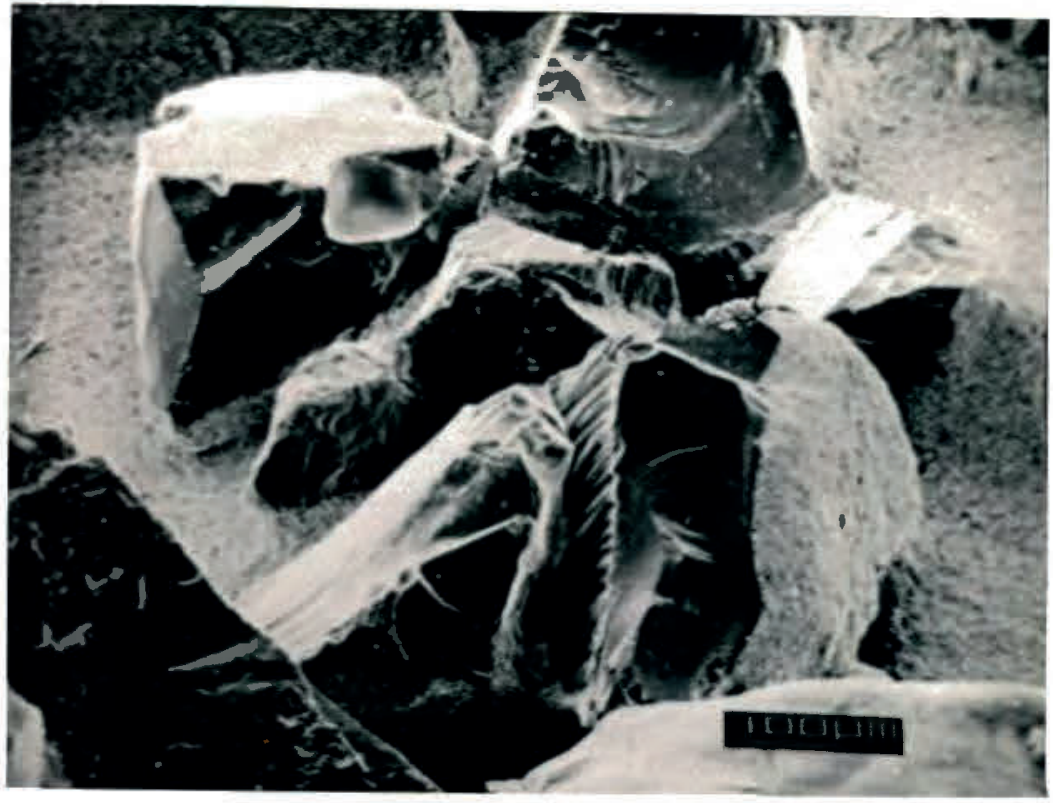

F1gure 20. Photomicrograph of Portland Iills Silt quartz grains showIng the angularity, extreme relief and varlably sized conchoidial breakage patterns which are typical of glacial-fluvial envircnments.

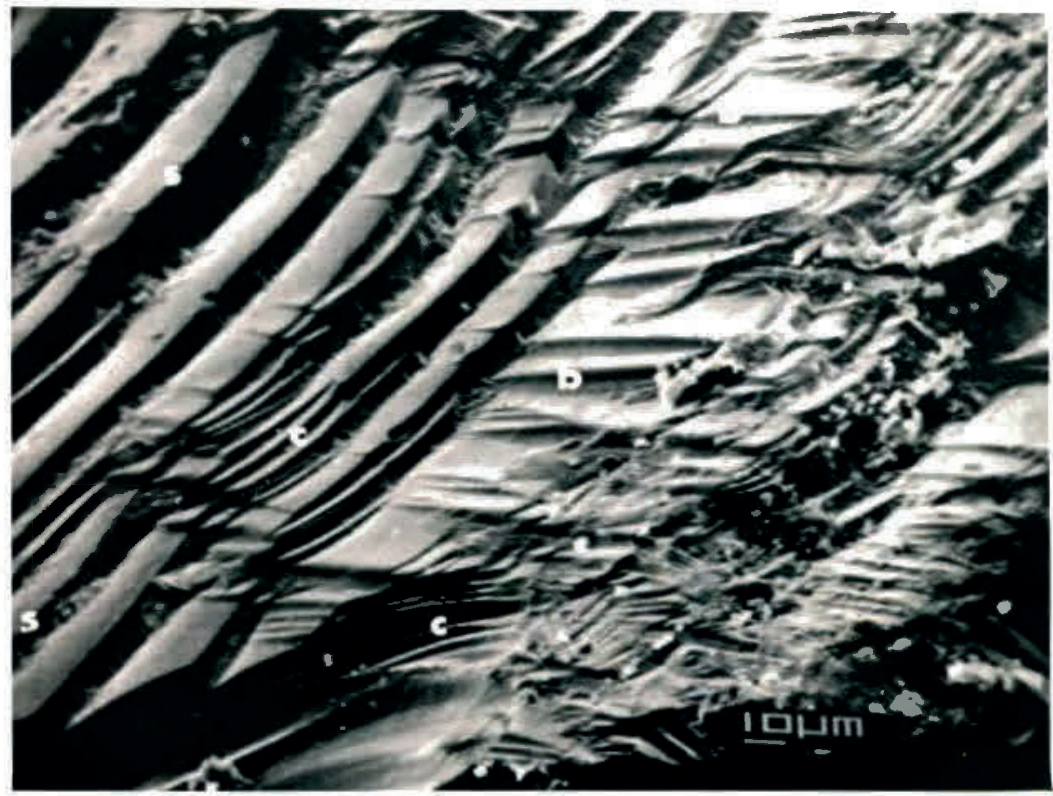

Figure 21. Photomicrograph of a Portland Hills Silt quartz grain showing typical glacial texcures (Krinsley and Dcnarue, 1968); semiparallel steps (s), arc-shaped steps (c) and imbricated breakage blocks (b). 


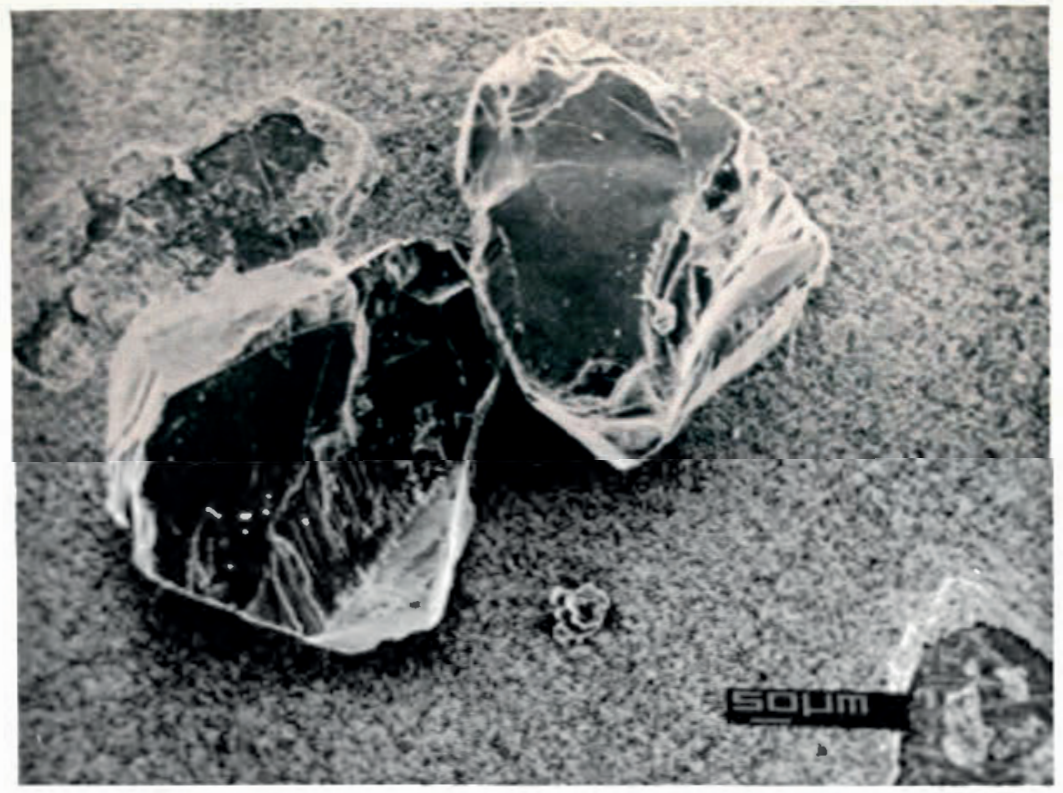

Figure 22. Photomicrograph of quartz graIns from Columbia River sand (Reed Island). Compare these with the Portland Hills Silt grains (Figure 20). 
COMPOSITION

Compositional analysis of the Portland Hills Silt involved four areas of study: light, heavy and clay mineral constituents, and fossil components. Of these, emphasis was placed upon the heavy minerals because of their greater importance as provinance indicators and correlation aids.

Light and heavy minerals from up to 17 of the 20 uniform-depth samples listed in Table 3, and 5 variable-depth samples from DAH76-6 were examined.

The clay-sized fraction of 3 Portland Hills Silt samples from DAH76-6 and the Skyline School section (see Appendix F) were also examined, mainly to confirm the clay mineral composition reported by Trimble (1963, p. 51).

\section{Laboratory Procedures}

All light and heavy minerals were split from a composite size fraction of each sample. The size interval included coarse silt and fine sand particles ranging from .053 to $.149 \mathrm{~mm}$ in diameter. This size fraction was chosen largely to facilitate a reliable comparison between the Portland Hills Silt and the Willamette Silt formations. Detailed petrographic work on the latter unit was done by Glenn (1965). He used identical size limits in his heavy mineral analyses. A preliminary grain study of the Portland Hills Silt Indicated that an acid pretreatment was unnecessary for proper mineral identification. Complete or partial granulometric analysis of individual 
samples was followed, therefore, by sizing and separation of the light and heavy minerals using tetrabromoethane (specific gravity 2.96). Representative splits from the total light and heavy mineral fractions were then mounted in epoxy resin. To aid in the identification of plagioclase and alkali feldspar in the light fraction, these minerals were etched and stained using procedures outlined by Carver (1971, p. 524). Mineral frequencies were determined by grain count, using standard petrographic techniques.

Clay mineral analyses were performed using standard x-ray diffraction methods (Cu $\alpha$ radiation, Nickel filter). Sample pretreatment included dispersion, isolation of the clay fraction (.002-.004 mm) and treatments for the removal of organic matter and iron. Several mounts of the oriented particle, ceramic tile type (Carver, 1971, p. 533) were prepared from each sample. These were variously left untreated, baked at $400^{\circ} \mathrm{C}$ ( 1 hour), baked at $550^{\circ} \mathrm{C}$ ( 1 hour), or treated with DMSO (Dimethyl Sulfoxide) before x-raying. Clay particle morphology was determined by electron microscopy of settled clay mounts.

\section{Mineral Composition}

Light Minerals. The results of 5 Portland Hills Silt light mineral analyses are shown in Table 5 .

The data indicate that quartz grains make up about 40 percent of the total light mineral fraction. Lesser quantities of plagioclase and alkali feldspars combined compose an approximately equal percentage. Minerals of the mica group, acid rock fragments and volcanic glass constitute progressively smaller portions. Carbonates are entirely 


\section{TABLE 5}

LIGHT MINERALS IN 5 WIDESPREAD, UNIFORM DEPTH PORTLAND HILLS SILT SAMPLES

FROM THE TUALATIN MOUNTAINS

\begin{tabular}{|c|c|c|c|c|c|}
\hline \multirow[t]{2}{*}{ MINERAL } & \multicolumn{4}{|c|}{ SAMPLE DESIGNATION } & \multirow[b]{2}{*}{$76-33$} \\
\hline & DAH76-6c & DAH76-5 & DAH 76-2 & $76-113$ & \\
\hline Quartz & 81 & 72 & 80 & 87 & 75 \\
\hline Chert & 2 & 4 & 2 & 1 & 3 \\
\hline \multicolumn{6}{|l|}{ Alkal1 } \\
\hline Feldspar & 37 & 33 & 29 & 35 & 34 \\
\hline Plagloclase & 54 & 70 & 63 & 44 & 56 \\
\hline Volcantc Glass & 1 & 3 & 8 & 6 & 8 \\
\hline \multicolumn{6}{|l|}{ Acid Rock } \\
\hline Fragments & 5 & 4 & 5 & 2 & 4 \\
\hline \multicolumn{6}{|l|}{ Mafic Rock } \\
\hline Fragments & -- & 2 & 1 & - & -- \\
\hline M1ca Group & 16 & 8 & 8 & 21 & 11 \\
\hline Others & 4 & 4 & 4 & 4 & 10 \\
\hline Total & 200 & 200 & 200 & 200 & 200 \\
\hline
\end{tabular}


absent in the Portland Hills Silt. Even silt from unoxidized zones or deep auger holes showed no evidence of effervescence, with application of hydrochloric acid.

Quartz grains in the Portland Hills Silt consist predominantly of clear, monocrystalline fragments showling straight or only slightly undulose extinction. Many of the grains contain fluid filled vacuoles or microlites. The vacuoles are often aligned in strings which span the width of the particle.

Feldspar gralns, on the other hand, generally show weak to moderate alteration, appear clouded, and often contain numerous micro11tes. The alkali feldspars are dominated by relatively untwinned grains of orthoclase and tarton-twinned microcline. Plagloclase feldspars are largely albitic in composition, with anorthite contents (as determined by symmetrical zone extinction) ranging from about $10-30$ percent by weight.

Varying proportions of colorless muscovite and leached, goldenyellow blotite (Folk, 1968, p. 87) make up the mica group minerals. Both are subrounded to rounded and plate-11ke in form, and are of ten so thin as to appear isotropic.

Volcanic glass is found as colorless to brownish-gold fragments in differing stages of devitrification. Some appear palagonitic (Kerr, 1959, p. 424) while others, with a moderate negative relief, are siliceous in composition (Folk, 1968, p. 86).

Fine grained actdic rock fragments composed of ferromagnesian minerals with alkali feldspar or quartz far outnumber their mafic counterparts in all samples. 
Table 6 summarizes the light mineral composition and grain morphology of all the Portland Hills Silt samples. These include those listed In Table 5, plus 6 samples of equivalent silts (see page 103) from the outlying Portland-Tualatin Valley region.

Heavy Minerals. Table 7 lists the heavy mineral components and their frequency in 17 widely distributed uniform depth samples from the Tualatin Mountains.

The grain counts show a strong predominance of blue-green hornblende in the Portland Hills Silt heavy mineral suite. Less prevalent are the opaque minerals, epidote group minerals, augite, mica, lamprobolite and rock fragments, in decreasing order of abundance. Garnet, tremolite, zircon, hypersthene, volcanic glass, kyanite, tourmaline, staurolite, apatite, monazite, sphene, sillimanite and possibly pyrophyllite compose between a trace and 2 percent each of the total fraction.

Both the blue-green and yellow-reddish brown (lamprobolite) amphiboles occur as subangular to subrounded, elongate cleavage fragments, which normally show strong pleochroism. Tremolite grains, however, are colorless and more elongate, with parallel grain boundarles.

Augite occurs mainly as pale-green to colorless grains of prismatic habit. Terminations of these grains are often irregular or jagged. A few augite grains are composed of a coarse aggregate of subhedral crystals. Hypersthene shows characteristic green/pink pleochroism and an elongate, prismatic shape.

Yellow-green pistacite (negative 2V) constitutes a good portion 
TABLE 6

AVERAGE PERCENT AND GRAIN MORPHOLOGY OF

LIGHT MINERALS IN 11 PORTLAND

HILLS SILT SAMPLES*

\begin{tabular}{|c|c|c|c|c|}
\hline MINERALS & $\begin{array}{l}\text { AVERAGE } \\
\text { PERCENT } \\
\end{array}$ & SHAPE & ROUNDING & $\begin{array}{l}\text { SURFACE } \\
\text { TEXTURE }\end{array}$ \\
\hline $\begin{array}{l}\text { Quartz } \\
\text { Chert } \\
\text { Alkalf }\end{array}$ & $\begin{array}{r}40.6 \\
0.9\end{array}$ & $\begin{array}{c}\text { eq.-el. } \\
\text { eq. }\end{array}$ & $\begin{array}{l}\mathbf{A - s A} \\
\mathbf{s A}-\mathbf{s R}\end{array}$ & $\begin{array}{l}\text { fr. } \\
\text { gm. }\end{array}$ \\
\hline $\begin{array}{l}\text { Alkali } \\
\text { Feldspar } \\
\text { Plagloclase } \\
\text { Volcanic Glass } \\
\text { Acid Rock }\end{array}$ & $\begin{array}{r}18.3 \\
25.5 \\
2.5\end{array}$ & $\begin{array}{l}e q .-e 1 . \\
e q .-e 1 \\
\text { el. }\end{array}$ & $\begin{array}{c}A-8 A \\
A-8 A \\
A\end{array}$ & $\begin{array}{l}\text { etch. } \\
\text { etch. } \\
\text { sm. }\end{array}$ \\
\hline $\begin{array}{l}\text { Fragments } \\
\text { Maflc Rock }\end{array}$ & 2.8 & eq. & $\mathbf{g} \mathbf{R}$ & sm.-1rreg. \\
\hline $\begin{array}{l}\text { Fragments } \\
\text { Mica Group } \\
\text { Others }\end{array}$ & $\begin{array}{l}0.2 \\
6.7 \\
2.3\end{array}$ & $\begin{array}{r}\text { eq. } \\
\text { platy }\end{array}$ & $\begin{array}{c}\mathbf{s R} \\
\mathbf{s R}-\mathbf{R}\end{array}$ & $\begin{array}{l}\text { sm.-1rreg. } \\
\text { sm. }\end{array}$ \\
\hline
\end{tabular}

*Includes samples from Table 5 and 6 samples from the outlying Portland-Tualatin Valley region.
$T=$ Trace
eq. = Equant
e1. = Elongete
R= Rounded
$A=$ Angular
$\mathbf{s}=$ Sub-

etch. = Etched

$\mathrm{fr} .=$ Fresh

sm.= Smooth

irreg.= Irregular 
TABLE 7

HEAVY MINERALS IN 17 WIDESPREAD, UNIFORM DEPTH PORTLAND HILLS

SILT SAMPLES FROM THE TUALATIN MOUNTAINS

\begin{tabular}{|c|c|c|c|c|c|c|c|c|c|}
\hline MINERALS & $75-33$ & $75-45$ & $75-83$ & $\begin{array}{l}\text { SAMPLE } \\
76-7\end{array}$ & $\begin{array}{c}\text { DESIGNAT } \\
76-15 \\
\end{array}$ & $76-17$ & $76-32$ & $76-103$ & $76-112$ \\
\hline Hornblende & 82 & 57 & 73 & 73 & 100 & 82 & 78 & 79 & 105 \\
\hline Lamprobolite & 6 & 5 & 6 & 9 & 10 & 5 & 6 & 2 & 1 \\
\hline Tremolite & 2 & 1 & 2 & 3 & 1 & 2 & 3 & 3 & 3 \\
\hline Actinolite & - & - & - & -- & 1 & - & - & -- & -- \\
\hline Auglte & 19 & 31 & 22 & 29 & 12 & 15 & 14 & 24 & 12 \\
\hline Hypers thene & 3 & 2 & - & 1 & - & 2 & 2 & - & 1 \\
\hline Epidote Group & 26 & 24 & 27 & 25 & 21 & 26 & 35 & 23 & 24 \\
\hline Garnet & 4 & 1 & 1 & 2 & 5 & 1 & 1 & 1 & 6 \\
\hline Sphene & - & 1 . & 2 & 1 & - & - & 1 & - & -- \\
\hline Z1rcon & 4 & 1 & 3 & 3 & $\mathrm{~T} *$ & 2 & 3 & 3 & 3 \\
\hline Kyanite & 1 & 2 & -- & $\mathbf{T}$ & $\mathrm{T}$ & - & -- & 5 & -- \\
\hline Tourmaline & 2 & $\mathbf{T}$ & 1 & 1 & - & 1 & 1 & 1 & 1 \\
\hline Pyrophyllite & $\mathrm{T} ?$ & $\mathrm{~T} ?$ & $\mathrm{~T} ?$ & $\mathrm{~T} ?$ & $T ?$ & $\mathrm{~T} ?$ & $\mathrm{~T} ?$ & $\mathrm{~T} ?$ & $\mathrm{~T} ?$ \\
\hline Staurolite & - & - & 2 & 2 & 1 & - & - & 1 & - \\
\hline Andalusite & $T^{*}$ & -- & - & - & -- & -- & -- & - & -- \\
\hline S1111manite & $\mathbf{T}$ & - & - & -- & -- & -- & -- & - & -- \\
\hline Monazite & -- & -- & 1 & -- & -- & -- & -- & - & 1 \\
\hline MIca Group & 2 & 8 & 4 & 7 & 3 & 13 & 7 & 14 & 7 \\
\hline Apatite & -- & -- & - & -- & $\mathbf{T}$ & - & -- & - & 2 \\
\hline Hematite & 13 & 16 & 13 & 7 & 12 & 13 & 14 & 9 & 11 \\
\hline Leucoxene & 3 & 2 & 5 & 3 & 3 & 4 & 5 & 1 & 4 \\
\hline Magneti te/Ilmenite & 16 & 30 & 23 & 16 & 17 & 25 & 20 & $2 \overline{6}$ & 10 \\
\hline Rock Fragments & 4 & 3 & 5 & 8 & 7 & 2 & - & 2 & 3 \\
\hline Volcanic Glass & 1 & 3 & 2 & 2 & 2 & 1 & -- & - & - \\
\hline Others & 12 & 13 & 8 & 7 & 6 & 6 & 10 & 6 & 6 \\
\hline Total & 200 & 200 & 200 & 200 & 200 & 200 & 200 & 200 & 200 \\
\hline
\end{tabular}

*Minerals were noted but did not come under the cross halrs during the counting traverses. 
TABLE 7 Continued

\begin{tabular}{|c|c|c|c|c|c|c|c|c|}
\hline \multirow[t]{2}{*}{ MINERALS } & \multicolumn{7}{|c|}{ SAMPLE DES IGNATION } & \multirow[b]{2}{*}{ DAH 76-7 } \\
\hline & $76-113$ & $76-160$ & $76-164$ & $\mathrm{AH} 76-13$ & DAH 76-5 & DAH76-2 & $76-162$ & \\
\hline Hornblende & 58 & 75 & 82 & 85 & 88 & 88 & 94 & 89 \\
\hline Lamprobolite & 4 & 6 & 5 & 3 & 9 & 5 & 2 & 7 \\
\hline Tremolite & 2 & 2 & 3 & -- & $\mathbf{T}$ & 4 & 2 & 1 \\
\hline Actinolite & -- & -- & - & - & 1 & -- & -- & -- \\
\hline Augite & 25 & 23 & 23 & 12 & 18 & 15 & 20 & 20 \\
\hline Hypers thene & 2 & -- & 1 & -- & 4 & -- & -- & -- \\
\hline Epidote Group & 36 & 35 & 36 & 40 & 25 & 36 & 31 & 33 \\
\hline Garnet & 1 & 2 & 1 & 3 & 6 & 3 & 6 & 2 \\
\hline Sphene & -- & -- & -- & -- & 1 & -- & -- & $\mathrm{T}$ \\
\hline Zircon & 4 & $\mathbf{T}$ & 1 & $\mathbf{T}$ & -- & 2 & 2 & $\mathrm{~T}$ \\
\hline Kyanite & $\mathrm{T}^{*}$ & $\mathbf{T}$ & 1 & $\mathrm{~T}$ & 1 & $\mathbf{T}$ & 1 & $T$ \\
\hline Tourmaline & -- & $\mathrm{T}$ & 1 & -- & -- & -- & -- & 1 \\
\hline Pyrophyllite & $\mathrm{T} ?$ & $\mathrm{~T} ?$ & $T ?$ & $\mathrm{~T} ?$ & $T ?$ & $\mathrm{~T} ?$ & $\mathrm{~T}$ ? & $\mathrm{T} ?$ \\
\hline Staurolite & -- & -- & -- & 1 & - & - & -- & -- \\
\hline Andalusite & -- & -- & -- & - & -- & -- & -- & -- \\
\hline S1111manite & 1 & -- & -- & -- & -- & -- & -- & -- \\
\hline Monazite & -- & 1 & $\mathrm{~T}$ & 2 & $\mathbf{T}$ & 1 & $\mathbf{T}$ & -- \\
\hline Mica Group & 6 & 6 & 7 & 8 & 9 & 9 & 5 & 7 \\
\hline Apat1te & -- & -- & -- & -- & - & $\mathbf{T}$ & 1 & 3 \\
\hline Hematite & 24 & 12 & 12 & 13 & 8 & 14 & 14 & 13 \\
\hline Leucoxene & 4 & 6 & 6 & 3 & 4 & 3 & 3 & 3 \\
\hline Magnetite/I1menite & 24 & 13 & 14 & 16 & 15 & 13 & 8 & 99 \\
\hline Rock Fragments & 6 & 6 & -- & 8 & 4 & 5 & 3 & 3 \\
\hline Volcantc Glass & -- & -- & - & -- & 2 & - & 2 & 1 \\
\hline Others & 9 & 6 & 7 & 6 & 5 & 2 & 7 & 8 \\
\hline Total & 200 & 200 & 200 & 200 & 200 & 200 & 200 & 200 \\
\hline
\end{tabular}

*M1nerals were noted but did not come under the cross hairs during the counting traverses. 
of the epidote group minerals in the Portland Hills Silt. It appears e1ther as f1ne, granular aggregates or as somewhat elongated prismatic fragments. Though zo1site and clinozolste also occur as elongate, prismatic grains, both exhibit lower order, and oftentimes anomalous Interference colors (Milner, 1962, p. 86, 102).

Opaque minerals consist of hematite (Including limonitic grains), magnetite and 1lmenite, and some leucoxene. The hematite occurs as amorphous masses or aggregates which appear yellowish to reddish-brown In reflected 11ght. In contrast, magnetite is characterized by well developed, black octahedral crystals or minute, faceted grains. Its dominance over 1lmenite in the heavy mineral sulte is reflected by a high welght percentage of magnet1te (average 9.9 percent), as determined by magnet1c separation.

Garnets are commonly subangular and equant in form and colorless or pale yellow. Tourmaline varietles include a moderately pleochroic yellow, which is most often seen, a strongly pleochrolc dark green and a colorless variety. The unknown mineral fraction contains chiefly undifferentlated augite, epidote and hornblende minerals.

Although pyrophyllite was not positively identified in the heavy mineral sulte, very thin "Isotroplc" flakes (Milner, 1962, p. 170) of that mineral would be Indistinguishable from simllar representatives of the mica group.

The heavy mineral composition, average percent and individual grain morphology for those samples listed in Table 7 are given in Table 8.

The unusual rounding of the more durable zircon and tourmaline 
TABLE 8

AVERAGE PERCENT AND GRAIN MORPHOLOGY OF HEAVY MINERALS IN 17 PORTLAND

HILLS SILT SAMPLES*

\begin{tabular}{|c|c|c|c|c|}
\hline MINERALS & $\begin{array}{l}\text { AVERAGE } \\
\text { PERCENT } \\
\end{array}$ & SHAPE & ROUNDING & $\begin{array}{l}\text { SURFACE } \\
\text { TEXTURE }\end{array}$ \\
\hline $\begin{array}{l}\text { Hornblende } \\
\text { Lamprobolite } \\
\text { Tremolite } \\
\text { Actinolite } \\
\text { Augite } \\
\text { Hypersthene } \\
\text { Epidote Group } \\
\text { Garnet } \\
\text { Sphene } \\
\text { Z1rcon } \\
\text { Kyanite } \\
\text { Tourmaline } \\
\text { Pyrophyllte } \\
\text { Staurolite } \\
\text { Andalusite } \\
\text { S1lilmanite } \\
\text { Monazite } \\
\text { Mica Group } \\
\text { Apat1te } \\
\text { Hematite } \\
\text { Leucoxene } \\
\text { Magnetite/Ilmentte } \\
\text { Rock Fragments } \\
\text { Volcanic Glass } \\
\text { Others }\end{array}$ & $\begin{array}{r}40.8 \\
2.8 \\
1.0 \\
0.1 \\
9.9 \\
0.5 \\
14.9 \\
1.4 \\
0.2 \\
0.6 \\
0.3 \\
0.3 \\
T(?) \\
0.2 \\
T \\
T \\
0.2 \\
3.2 \\
0.2 \\
6.4 \\
0.5 \\
8.7 \\
2.1 \\
0.5 \\
3.4\end{array}$ & $\begin{array}{l}\text { el. } \\
\text { el. } \\
\text { el. } \\
\text { el. } \\
\text { el.-eq. } \\
\text { el. } \\
\text { eq.-el. } \\
\text { eq. } \\
\text { eq. } \\
\text { eq.-el. } \\
\text { tabular } \\
\text { el. } \\
-- \\
-- \\
-- \\
\text { el. } \\
\text { eq. } \\
\text { platy } \\
\text { eq.-el. } \\
\text { eq. } \\
\text { eq. } \\
\text { eq. } \\
\text { eq.-el. } \\
\text { el. }\end{array}$ & $\begin{array}{c}\text { sA-sR } \\
\text { sA-sR } \\
\text { sA-sR } \\
\text { sA-sR } \\
\text { A-R } \\
\text { sA-sR } \\
\text { sA-sR } \\
\text { sA } \\
\text { sR } \\
\text { sR-R } \\
\text { sA } \\
\text { sR } \\
-- \\
-- \\
-- \\
\text { sA-sR } \\
\text { sR } \\
\text { R-WR } \\
\text { sR-R } \\
\text { R } \\
\text { R } \\
\text { sA-R } \\
\text { sR-R } \\
\text { A }\end{array}$ & $\begin{array}{l}\text { fr. } \\
\text { fr. } \\
\text { fr. } \\
\text { fr.-sm. } \\
\text { etch.-sm. } \\
\text { fr.-etch. } \\
\text { etch.-sm. } \\
\text { sm. } \\
\text { etch. (?) } \\
\text { pol. } \\
\text { sm. } \\
\text { pol. } \\
\text {-- } \\
\text {-- } \\
\text {-- } \\
\text { sm. } \\
\text { sm. } \\
\text { sm. } \\
\text { pol. } \\
\text { Irreg. } \\
\text { Irreg. } \\
\text { sm. -fr. } \\
\text { sm. } \\
\text { sm. }\end{array}$ \\
\hline
\end{tabular}

\footnotetext{
*Samples from Table 7.

Te Trace

eq. = Equant

el.= Elongate

$\mathbf{R}=$ Rounded

A= Angular

$\mathbf{s}=$ Sub-

wr Well

etch. = Etched

fr. $=$ Fresh

sm. $=$ Smooth

pol. = Pollshed

Irreg. = Irregular
} 
minerals, as compared to that of hornblende, epidote and augite, may be partly due to 1mpact fracturing (Folk, 1968, p. 14); that is, the break up, rather than rounding of larger, cleavable grains such as hornblende and augite. More $11 \mathrm{kely}$, however, $21 \mathrm{rcon}$ and tourmaline grains have originated from older "recycled" sedimentary rocks (Folk, 1968, p. 14). This conclusion is supported by the presence of rounded and wellrounded flakes of mica in the silt. According to Folk (1968, p. 88), rounded mica flakes are rarely seen in sediments and require "exceptional conditions" of prolonged abrasion. Thus, like zircon and tourmaline, it too must be derived from a source quite different from that of the more abundant, angular minerals.

Clay Minerals. A previous determination of the clay minerals present in the Portland Hills Silt was done by A. J. Gude, III, using x-ray diffraction methods (Trimble, 1963, p. 51). He found kaolinite and illite clay minerals with another clay described as possibly montmorillonite or chlorite.

The present investigation tends to confirm Gude's work. X-ray diffraction studies of 3 Portland Hills Silt samples are summarized in Table 9. The data is interpreted to represent the following clay minerals: Mixed-layer montmorillonite or montmorillonite, illite, and disordered kaolinite.

A mixed-1ayer montmorillonite, such as interstratified montmorillonite-mica, is suspected because of (1) a 12-13 \& basal spacing rather than a 14-15 $\AA$ spacing typical of untreated montmorillonite (Milner, 1962, p. 322), and (2) because of subsequent lattice expansion after treatment with DMSO. 
TABLE 9

X-RAY DIFFRACTION DATA FOR THREE PORTLAND HILLS

SILT SAMPLES. RELATIVE INTENSITIES ARE

SHOWN IN PARENTHESES

\begin{tabular}{|c|c|c|c|c|c|c|c|c|}
\hline \multicolumn{4}{|c|}{ DAH76-6f } & \multicolumn{4}{|c|}{ DAH76-6a } & \multirow{2}{*}{$\begin{array}{l}76-126 \\
\text { UNTREATED }\end{array}$} \\
\hline UNTREATED & $\begin{array}{c}\text { BAKED } \\
\left(400^{\circ} \mathrm{C}\right)\end{array}$ & $\begin{array}{c}\text { BARED } \\
\left(550^{\circ} \mathrm{C}\right) \\
\end{array}$ & DMSO & UNTREATED & $\begin{array}{c}\text { BAKED } \\
\left(400^{\circ} \mathrm{C}\right) \\
\end{array}$ & $\begin{array}{c}\text { BAKED } \\
\left(550^{\circ} \mathrm{C}\right) \\
\end{array}$ & DMSO & \\
\hline $\begin{array}{r}12.67 \\
(26)\end{array}$ & $\begin{array}{r}9.604 \\
(23)\end{array}$ & $\begin{array}{r}9.654 \\
(30)\end{array}$ & $\begin{array}{r}20.10 \\
(10)\end{array}$ & $\begin{array}{c}12.891 \\
(27)\end{array}$ & $\begin{array}{r}9.653 \\
(22)\end{array}$ & $\begin{array}{r}9.710 \\
(31)\end{array}$ & $\begin{array}{r}18.39 \\
(10)\end{array}$ & $\begin{array}{r}12.27 \\
(32)\end{array}$ \\
\hline $\begin{array}{c}10.394 \\
(13)\end{array}$ & $\begin{array}{r}7.430 \\
(17)\end{array}$ & $\begin{array}{c}4.924 \\
(4)\end{array}$ & $\begin{array}{c}18.41 \\
(6)\end{array}$ & $\begin{array}{r}9.967 \\
(18)\end{array}$ & $\begin{array}{r}7.380 \\
(12)\end{array}$ & $\begin{array}{c}4.941 \\
(4)\end{array}$ & $\begin{array}{r}14.02 \\
(25)\end{array}$ & $\begin{array}{c}10.392 \\
(23)\end{array}$ \\
\hline $\begin{array}{r}7.493 \\
(11)\end{array}$ & $\begin{array}{c}4.844 \\
(2)\end{array}$ & $\begin{array}{l}3.399 \\
9(19)\end{array}$ & $\begin{array}{r}10.02 \\
(45)\end{array}$ & $\begin{array}{r}8.418 \\
(12)\end{array}$ & $\begin{array}{c}3.472 \\
(9)\end{array}$ & -- & $\begin{array}{c}11.32 \\
(3)\end{array}$ & $\begin{array}{r}7.430 \\
(17)\end{array}$ \\
\hline $\begin{array}{l}3.524 \\
(8)\end{array}$ & $\begin{array}{r}3.490 \\
(12)\end{array}$ & $\begin{array}{r}3.184 \\
(12)\end{array}$ & $\begin{array}{l}7.19 \\
(20)\end{array}$ & $\begin{array}{r}7.369 \\
(15)\end{array}$ & $\begin{array}{r}3.305 \\
(12)\end{array}$ & -- & $\begin{array}{l}9.93 \\
(15)\end{array}$ & $\begin{array}{r}3.517 \\
(14)\end{array}$ \\
\hline \multirow[t]{3}{*}{$\begin{array}{c}3.330 \\
(9)\end{array}$} & $\begin{array}{r}3.314 \\
(14)\end{array}$ & $\begin{array}{c}2.995 \\
(2)\end{array}$ & - & $\begin{array}{c}4.951 \\
\text { (3) }\end{array}$ & -- & & $\begin{array}{r}7.192 \\
(13)\end{array}$ & $\begin{array}{r}3.424 \\
(13)\end{array}$ \\
\hline & $\begin{array}{c}3.184 \\
(9)\end{array}$ & & -- & $\begin{array}{r}3.531 \\
(11)\end{array}$ & & & $\begin{array}{r}4.92 \\
(6)\end{array}$ & \\
\hline & & & & $\begin{array}{r}3.299 \\
(13)\end{array}$ & & & $\begin{array}{c}4.72 \\
(7)\end{array}$ & \\
\hline
\end{tabular}


Inttially, the relatively high $(7.48)$ and diffuse $7 \mathrm{R}$ kaolin peak was belleved to represent meta-halloysite (Brown, 1961, p. 72) rather than disordered kaolinite. However, electron microscopy of the less than .002 clay fraction later revealed a platy kaolinite morphology (Figure 23) instead of the tubular structure expected from meta halloystte (Brown, 1961, p. 313).

The presence of $14 \AA$ chlorites was discounted because of the absence of a 14 (001) peak and because of the complete loss of the 7 \& peak after baking at $550^{\circ} \mathrm{C}$ (Milner, 1962, p. 328).

Total Mineral Composition. Table 10 gives the total average mineral composition of the Portland Hills S1lt. The values are approximated on the assumption that the proportions indicated in the light and heavy mineral analyses are roughly constant throughout the coarser part $(>.004 \mathrm{~mm})$ of the size distribution. It is also assumed that the clay-sized fraction $(<.004 \mathrm{~mm})$ includes a small portion of quartz and feldspar constituents.

TABLE 10

TOTAL MINERAL COMPOSITION OF THE PORTLAND HILLS SILT

\begin{tabular}{lc}
\hline \multicolumn{1}{c}{ MINERAL } & $\begin{array}{c}\text { APPROXIMATE AVERAGE } \\
\text { PERCENT }\end{array}$ \\
\hline Quartz & 34.6 \\
Chert & 0.8 \\
Alkal1 & \\
$\quad$ Feldspar & 14.9 \\
Plagloclase & 21.4 \\
Volcantc Glass & 2.1 \\
Rock Fragments & 2.5 \\
Mica Group & 5.7 \\
Heavy Minerals & 3.0 \\
Clay Minerals & 15.0 \\
\hline
\end{tabular}




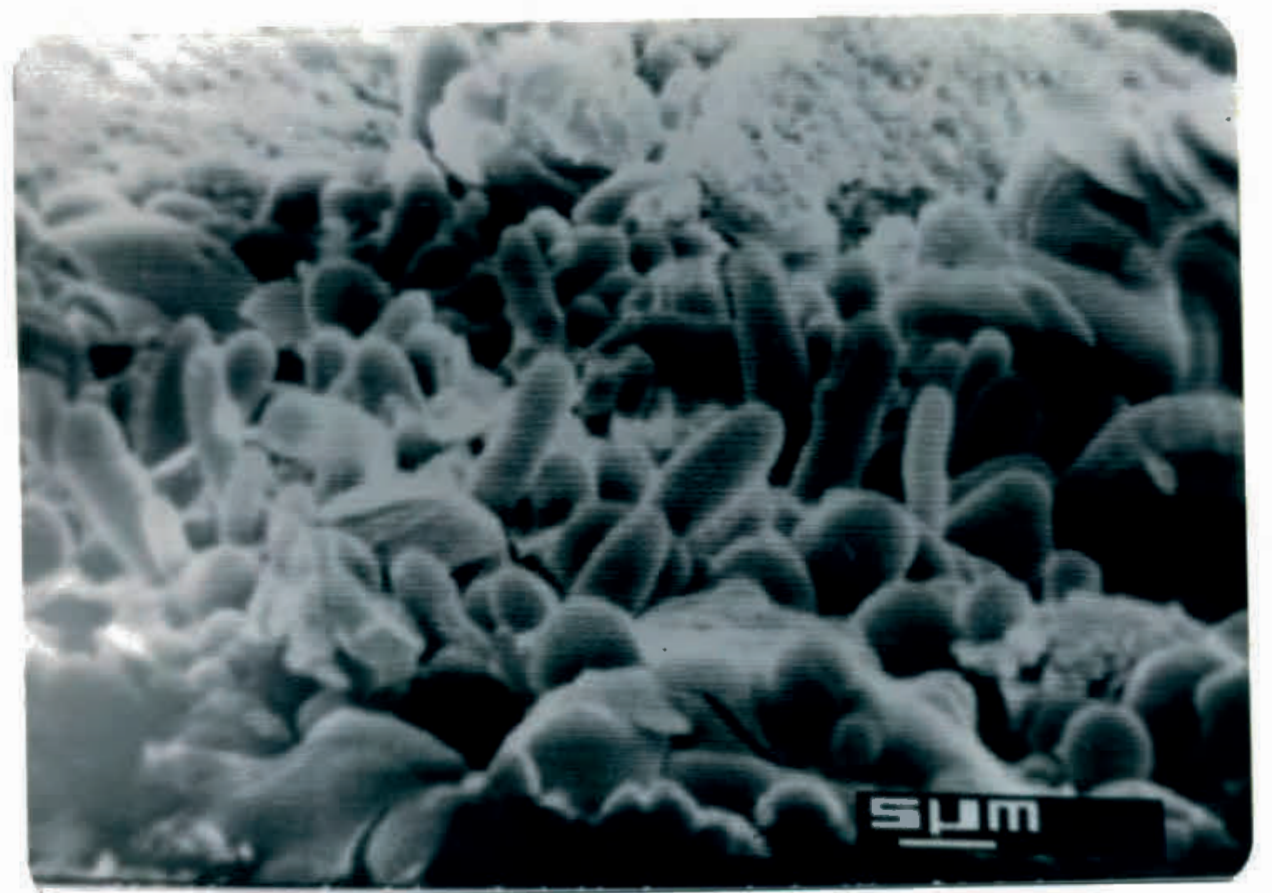

Figure 23. Photomicrograph showing the platy morphology of clay minerals in the Portland Hills Silt. 


\section{Fossi1 Components}

No mega- or micro-fossils were identified in the Portland Hills Silt at any time during the field or laboratory study. Occasionally, however, somewhat leached terrestrial gastropod shells were discovered in or near the ground surface.

During granulometric analysis, each sleve interval in the sand fraction (see p. 46 ) of 36 Portland Hills Silt samples were examined under a binocular microscope for fossil components. In addition, representative splits from the $.053-.149 \mathrm{~mm}$ size fraction in 3 widespread Tualatin Mountain samples were carefully inspected for possible micro-fossils.

The results of these efforts showed that diatoms and sponge spicules, though previously identified in the Portland Hills Silt (Wilkinson and others, 1946, p. 26; Lowry and Baldwin, 1952, p. 11), managed to elude the investigator. If present, these structures must be either very uncommon or are smaller than $.053 \mathrm{~mm}$ and were overlooked.

\section{CLASSIFICATION}

Textural classification schemes and nomenclature for sediments are numerous and varied (Pettijohn, 1975, p. 31-36). Folk's classification (1968) was chosen here because of its particular suitability for analysis of recent sediments, and to maintain continuity of nomenclature throughout the report.

Figure 24a shows Folk's textural classification for sediments lacking in gravel (p. 28). Superimposed is the "size-range" which 


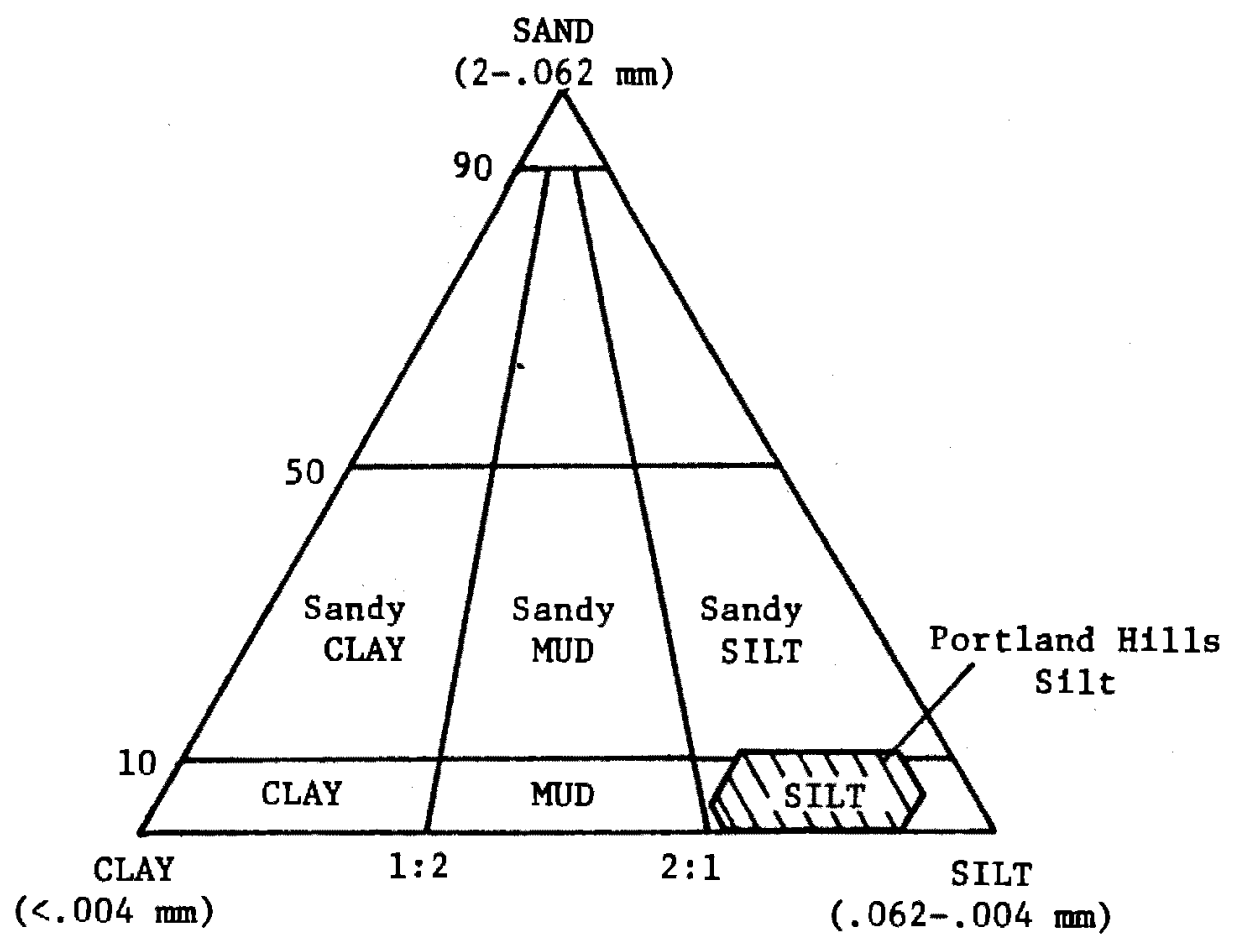

(a)

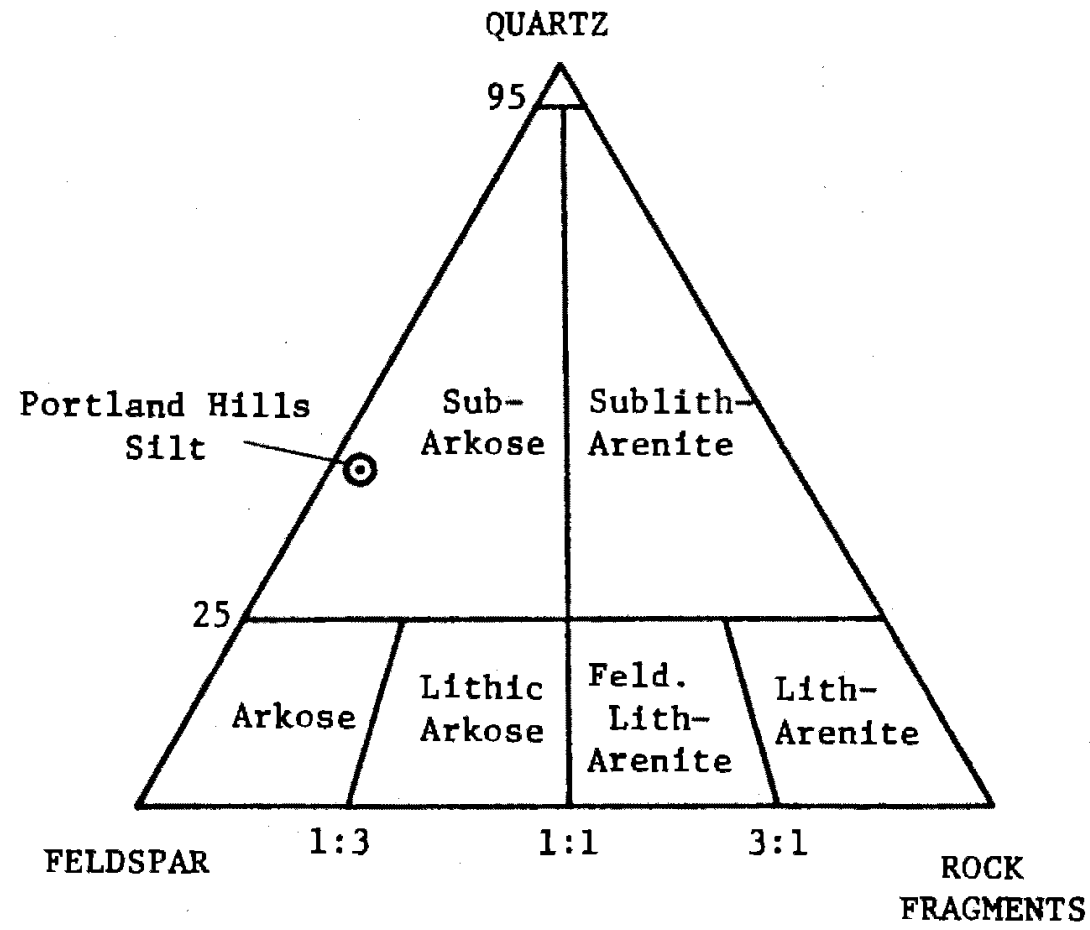

Figure 24. Classification of the Portland Hills Silt according to (a) texture (Folk, 1968, p. 28) and (b) composition (Folk, 1968, p. 128). 
statistically includes 95 percent of all Portland Hills Silt samples (see Granulometry, p. 49). One can see that Folk's "silt" class accommodates essentially all of these samples. It should be noted, however, that other classifications would regard portions of the Portland Hills Silt as "clayey" or "sandy" silt (Pettijohn, 1975, p. 33). Figure $24 \mathrm{~b}$ describes the total composition of the Portland H11ls Silt in relation to Folk's ternary quartz-feldspar-rock fragment diagram (p. 124): It is classified as a "subarkose."

The textural maturity of the formation (Folk, 1968, p. 102-108) is considered "immature" because of the greater than 5 percent clay content, and because of the poorly sorted and angular nature of the silt particles.

Finally, with the addition of mica-bearing term, the classification of the Portland Hills Silt is complete and reads as follows: Silt: micaceous, immature subarkose. 


\section{STRAT IGRAPHY}

The objectives of the present stratigraphic investigation were twofold: (1) to confirm the stratigraphic relations of the Portland Hills Silt with subjacent and superjacent formations in the Tualatin Mountains, especially the Boring Lava and Willamette Silt, and

(2) to determine the internal stratigraphy of the deposit, as reflected by lithologic variation.

In order to accomplish these goals, $6 \mathrm{~cm}$ wide, $5 \mathrm{~m}$ deep auger holes were bored at five Tualatin Mountain locations. Four borings were spaced at approximately regular intervals along a major east-west ridgeline crossing the mountains. The traverse parallels NW Springville Rd. and is located in the north half of the map area. Site designations and maximum elevations are, from east to west, DAH76-1, $84 \mathrm{~m}$ (275 ft); DAH76-2, $142 \mathrm{~m}(464 \mathrm{ft}) ; \operatorname{DAH} 76-3,275 \mathrm{~m}(900 \mathrm{ft}) ;$ and DAH76-4, $280 \mathrm{~m}$ $(920 \mathrm{ft})$.

The purpose of these borings was to detect (1) paleosols and lithologic variations within the Portland Hills Silt across the Tualatin Mountains and (2) the Tualatin Valley Willamette Silt/ Portland Hills Silt interface, if present.

A fifth boring was utilized to augment a deep road cut on the crest of the hills, along NW Skyline Blvd., SW $1 / 4$ SW 1/4, sec. 23, T.1N., R.1W. ${ }^{1}$ The designation, maximum elevation and depth of this

$1_{\text {Because of partial slumping of the outcrop face, an auger was }}$ also used to obtain reliable samples beneath the slumped areas. 
section are DAH76-6, $345 \mathrm{~m}(1130 \mathrm{ft})$, and $13.7 \mathrm{~m}$ (45 ft) respectively. The site was chosen to provide as deep and complete a section of Portland Hills Silt as possible with the available tools.

In addition to the augered sections, a sixth is described from a $7.3 \mathrm{~m}(24 \mathrm{ft})$ road cut along NW Skyline Rd., NW $1 / 4 \mathrm{NW} 1 / 4$, sec. 5 , T.1N., R.1W., near Skyline School. The outcrop was selected largely for correlation purposes and is located on a major ridgecrest in the northwest part of the map area. Its maximum elevation is $233 \mathrm{~m}$ (765 $f t)$.

Fifty-two variable depth samples from the above sections were analyzed for textural characteristics and organic carbon content. Organic carbon percentages were obtained using the hydrogen peroxide decomposition method (Carver, 1971, p. 588). The average error for replicate analyses is \pm 0.14 percent. Light and heavy minerals were also examined from selected samples.

\section{REGIONAL STRATIGRAPHY}

This section deals with the stratigraphic relationships between the Portland Hills Silt and its major boundary formations in the Tualatin Mountains. A sketch cross section illustrating these relationships is shown in Figure 25 (see Figure 26 for symbol explanations).

Due to time limitation and the lithologic similarity of Trimble's (1963) Pleistocene piedmont and terrace deposits exposed east and southeast of Portland, their association with the Portland Hills Silt was not studied in detail. 
FIGURE 25. Sketch Cross Section of the Tualatin Mountains Showing Surficial Stratigraphy

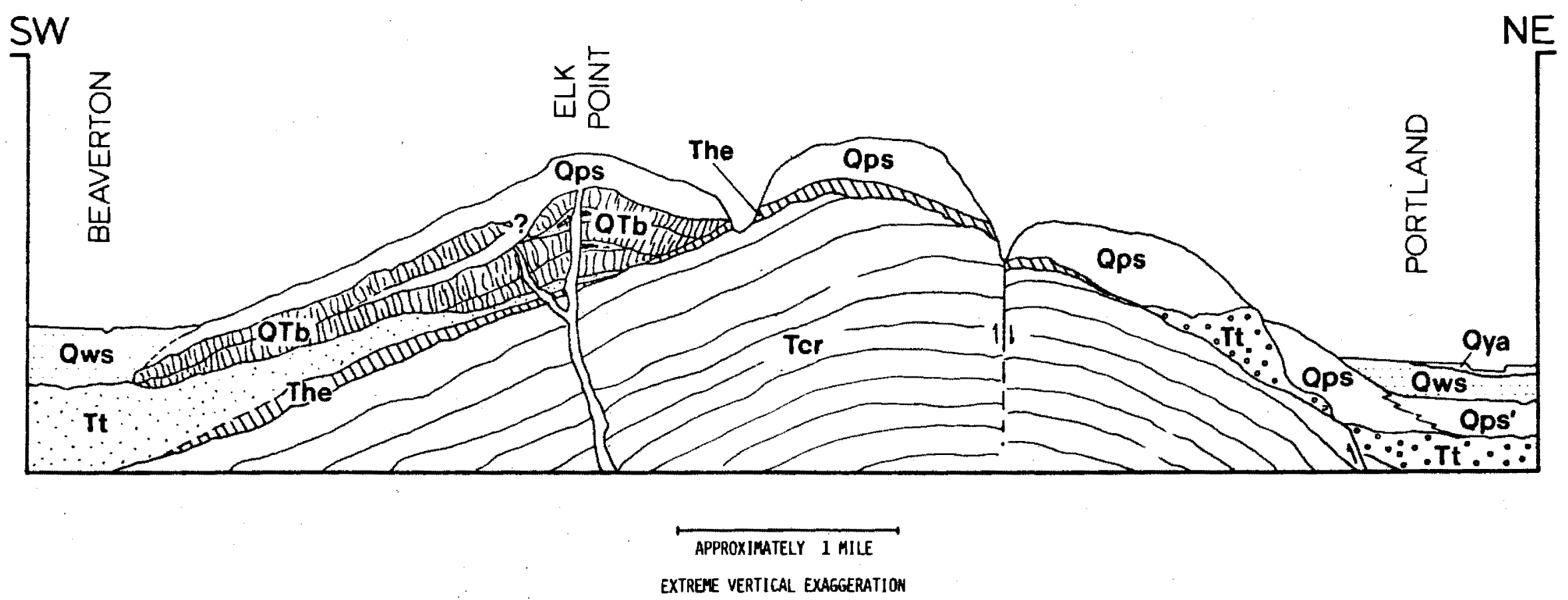



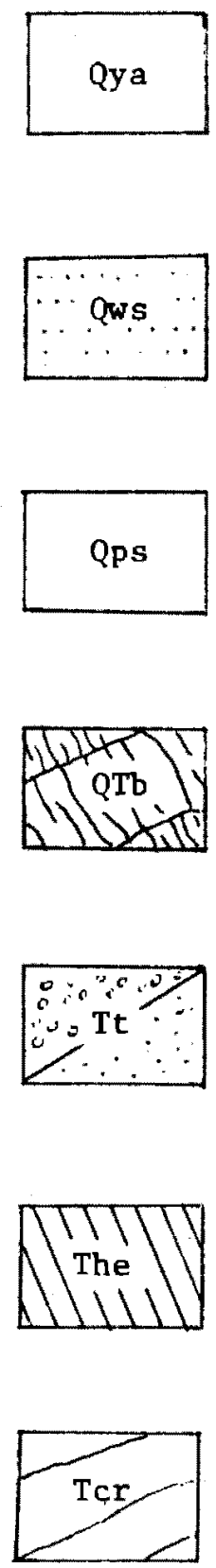

COLUMBIA RIVER BASALT

BORING LAVA

HELVETIA FORMATION$$
\text { of the flood plain }
$$

COLUMBIA RIVER BASALT

$$
\begin{aligned}
& \text { TROUTDALE FORMATION } \\
& \text { Open CIrcles- Conglomerate } \\
& \text { and Vitric sandstone } \\
& \text { Dot Pattern- Tualatin Valley } \\
& \text { equivalent }
\end{aligned}
$$

$$
\text { Qps' are equivalent silts }
$$

F1gure 26. Symbol explanation for F1gure 25. 
Columbia River Basalt

Previous workers agree that the Columbia River Basalt is much older than the Portland Hills Silt. The silt has been found to disconformably overlle erosional, saprolltic and laterized Columbla River Basalt surfaces (Darton, 1907, p. 11; Libbey and others, 1945, p. 10; Wilkinson and others, 1946, p. 24; Lowry and Baldwin, 1952, p. 10; Trimble, 1963, p. 51-52; Livingston, 1966, p. 45; Schlicker and Deacon, $1967, \mathrm{p} .30$ ).

The relationships are readily observed in numerous roadcuts along the eastern flank of the Tualatin Mountains.

\section{Helvetia Formation}

The Helvetia formation described by Schlicker and Deacon (1967) overlles Columbia River Basalt and is, In turn, unconformably overlain by the Portland Hills Silt deposit. Typlcally reddish-brown clayey and silty Helvetia sediments underlle Portland H11ls Silt at several localities, particularly in the north part of the Tualatin Mountains. One such exposure is a construction cut along the Burlington Northern Railroad tracks, north of Cornelius Pass, NE $1 / 4$ SW 1/4, sec. 30, T.2N., R.1W. It displays $1.5 \mathrm{~m}(5 \mathrm{ft})$ of the laterized, yet quartz bearing Helvetia, mantled by $4.6 \mathrm{~m}$ (15 ft) of yellowish-brown Portland Hills Silt. The maximum elevation of this outcrop is $113 \mathrm{~m}$ ( $370 \mathrm{ft}$ ). Another section, a roadcut along a private drive, NE $1 / 4 \mathrm{SW} 1 / 4$, sec. 4, T.1N., R.1E., ts present on the crest of the Tualatin Mountains. Here, Columbia River Basalt gives way upward to Helvetia sediments and finally Portland Hills Silt. 
A report on the Oregon Museum of Science and Industry/Washington Park Zoo landslide done by Shannon and Wilson, Inc. (1969) shows similar stratigraphic relationships at that locality. Some $18 \mathrm{~m}$ (60 ft) of light brown Portland Hills Silt overlies consecutively 2-6 m (6-20 ft) of Helvetia (a "red or reddish brown clay"), 6-9 m (20-30 $\mathrm{ft}$ ) of decomposed Columbia River Basalt and finally, fresher basalt. Exposures which revealed laterized Helvetia sediments grading downward into fresher, unweathered parent material were not discovered in the map area. Schlicker and Deacon (1967, p. 22), however, describe one such outcrop in which "mottled, brownish-gray siltstone has weathered upward into the reddish brown silty clay." Parent Helvetia material such as this may have easily been overlooked, or even misidentified, in isolated or poorly exposed sections.

\section{Sandy River Mudstone and Troutdale Formations}

Although the Sandy River Mudstone and Troutdale formations are lithologically distinct units in their eastern typesections (Trimble, 1963, p. 27), their Tualatin Valley counterparts are similar and indistinguishable (Schlicker and Deacon, 1967, p. 23; Hart and Newcomb, 1965, p. 22). For this reason these units are here discussed in combination.

Portland Hills Silt unconformably overlies quartzite bearing conglomerate and vitric sandstone of the Troutdale formation in numerous exposures on the eastern flank of the Tualatin Mountains. The silt mantles slightly weathered conglomerate along NW Leif Erikson Dr. in sections 56 and $57, \mathrm{~T} .1 \mathrm{~N} ., \mathrm{R} .1 \mathrm{E}$. , above $153 \mathrm{~m}$ (500 ft) 
and In Kings Heights above the old St. Vincent Hospital. In addition, a road cut adjacent to SW Boones Ferry Rd., NE 1/4 SW 1/4, sec. 33, T.1W., R.1E. (Figure 27), reveals $2-3 \mathrm{~m}(6-10 \mathrm{ft}$ ) of massive Portland Hills Silt atop Boring Lava. The basalt, in turn, overlies strongly weathered, stratified mudstone and vitric sandstone of the Troutdale formation.

Because of poor exposure and the compositional and textural similarity between Portland Hills Silt and much of the Tualatin Valley Troutdale sediments (see p. 105, Comparison of Similar Sediments), definite stratigraphic relationships between these formations are difficult to establish. One previously described section ( $p$. 31) does show what might be stratified Troutdale material beneath Portland Hills Silt, however.

Subsurface data reported by Schlicker and Deacon (1967) indicate that both the Tualatin Valley sediments and the Troutdale proper show analogous stratigraphic relations. And, though the exact relationship between these lithologic types is yet unclear, they are regarded as equivalent geologic time units. It is assumed, therefore, that the Portland Hills Silt unconformably overlies both the Sandy Mudstone and Troutdale proper, and their Tualatin Valley equivalents.

\section{Boring Lava}

Extrusives of the Boring volcanism are, for the most part, older than the Portland Hills Silt formation. The silt covers alternately weathered or saprolitic rock (Figure 28), eroded basalt surfaces (Figure 29), and rarely, fresher, scoriaceous rocks. In at least one 


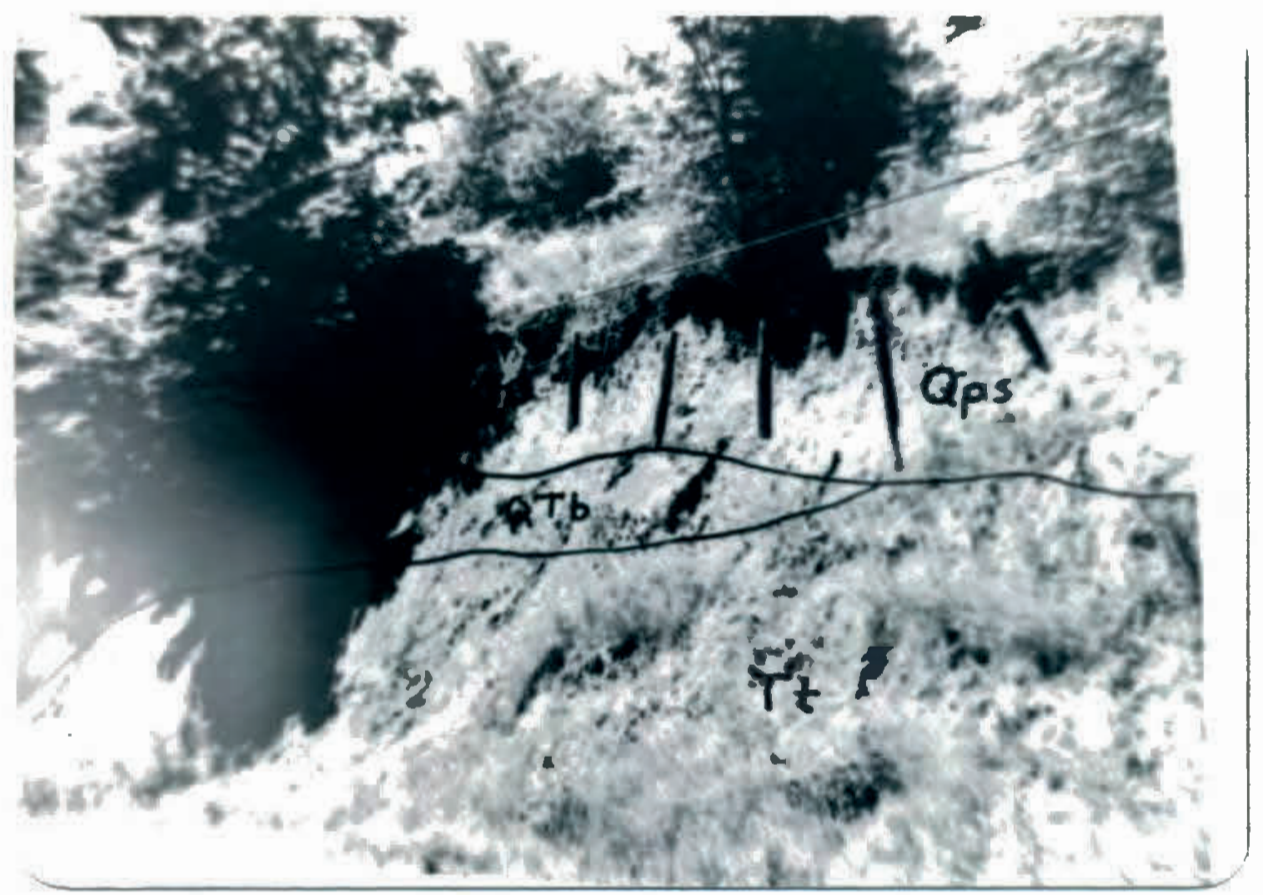

Figure 27. Road cut along SW Boones Ferry Road, NE $\frac{1}{4} S W \frac{1}{4}$, sec. 33, T.1S., R.IE., showing Portland Hills Silt atop Boring Lava and the Troutdale Formation. 


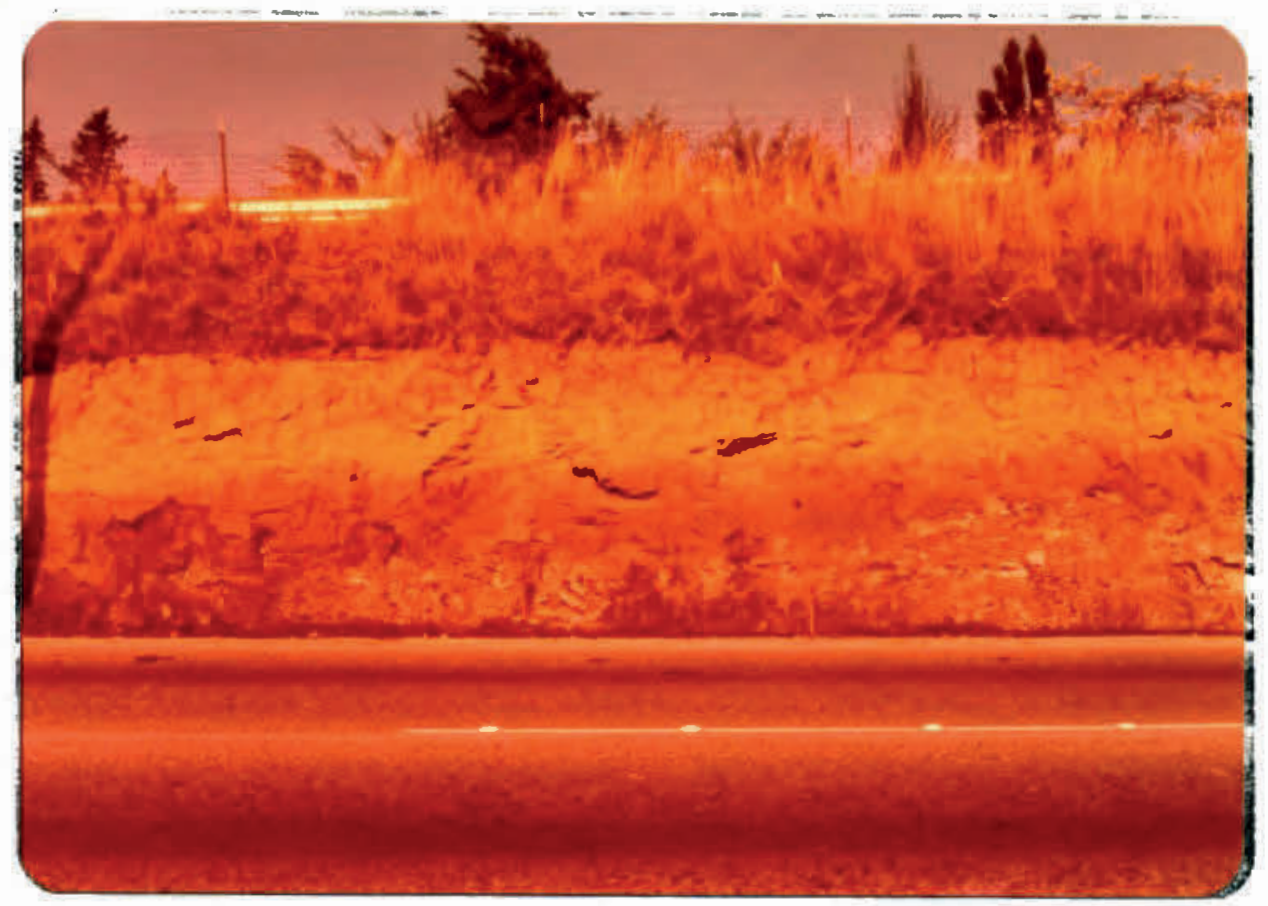

Figure 28. Road cut along the Baldock Freeway, NE $\frac{1}{4} \mathrm{SE}^{\frac{1}{4}}$, sec. 30, T.1S., R.IE., showing Portland Hills Silt overlying weathered Boring Lava. Note the vertical, blocky jointing in the silt.

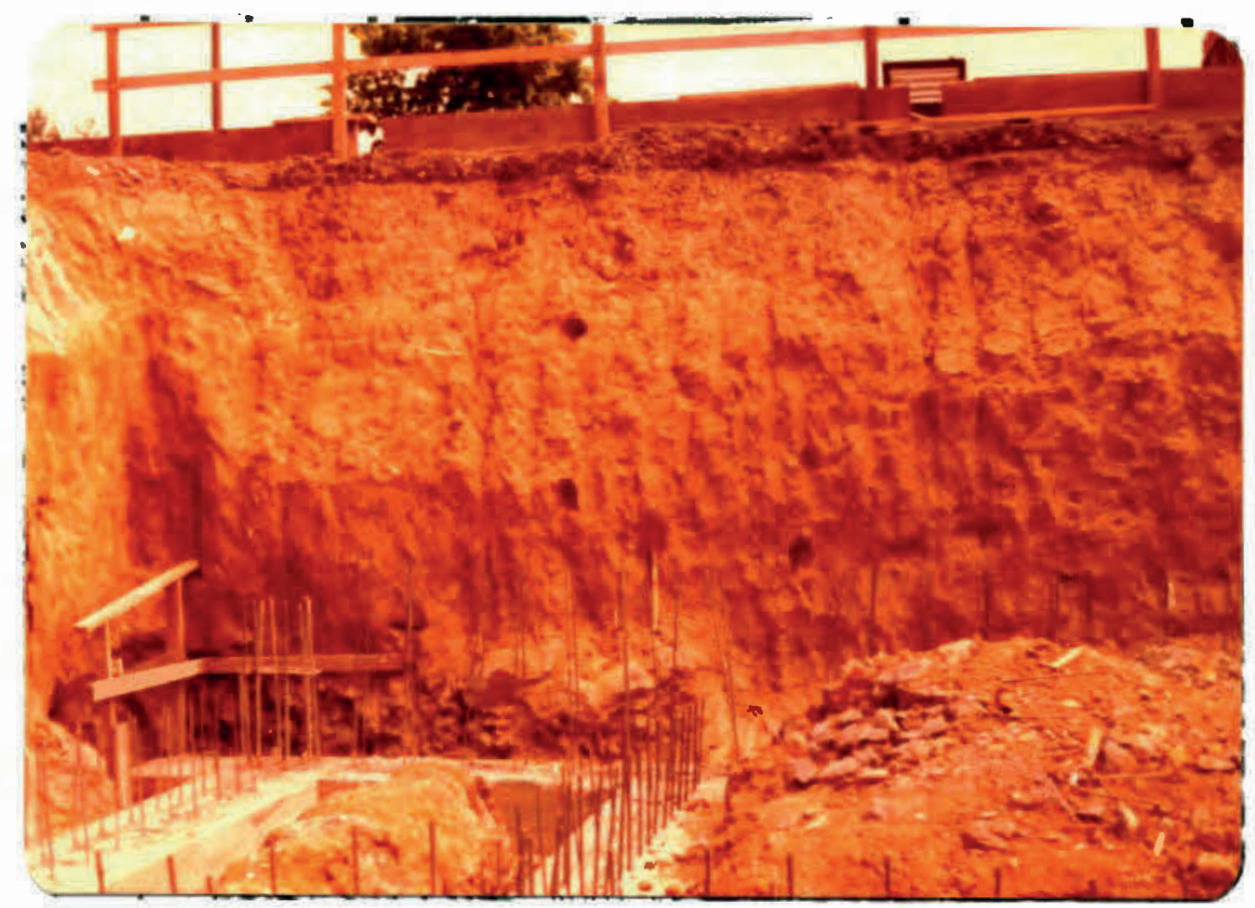

Figure 29. Construction cut at the St. Vircent Hospital (SW Barnes Road) showing Portland Hills Silt overlying Boring Lava. 
outcrop, however, Portland Hills Silt appears to be interbedded with the Boring volcanics.

A road cut near the intersection of SW Barnes and Miller Rds. (E1k Point), sec. 1, T.1S., R.1W., shows about $3 . \mathrm{m}$ (10 ft) of weathered, dark reddish-brown scoriaceous Boring material, which is overlain by 3-3.5 m (10-12 ft) of massive Portland Hills Silt (Figure 30). The Boring Lava is underlain by a moderate reddish-brown clayey silt which grades downward in color to a light yellowish-brown. Sampling and analysis showed this material to be compositionally and texturally very similar to the overlying Portland Hills Silt. The log of a nearby drill hole reveals about $4.5 \mathrm{~m}$ (15 ft) of the stratified (?) silt above a blue clay, and finally "dark volcanic scoria" of the Boring Lava. Carbon 14 age dates reported by Hammond (1975, p. 161) date wood fragments taken just above and within this scoria at greater than 40,000 years B.P.

The interbedded silt described above may be correlative with a "stiff silt unit" which is reportedly interstratified with Boring Lava less than one mile westward, beneath the St. Vincent Hospital site (A11en, 1974, p. 151).

It is entirely possible that these silts are actually part of the older, but lithologically similar Tualatin Valley Troutdale sediments.

\section{Willamette Silt}

The Willamette Silt was studied in detail by Glenn (1965). He concluded ( $p .189$ ) that the sediments were laid down in "a continuously ponded body of water" resulting from "a more rapid aggradation in the 


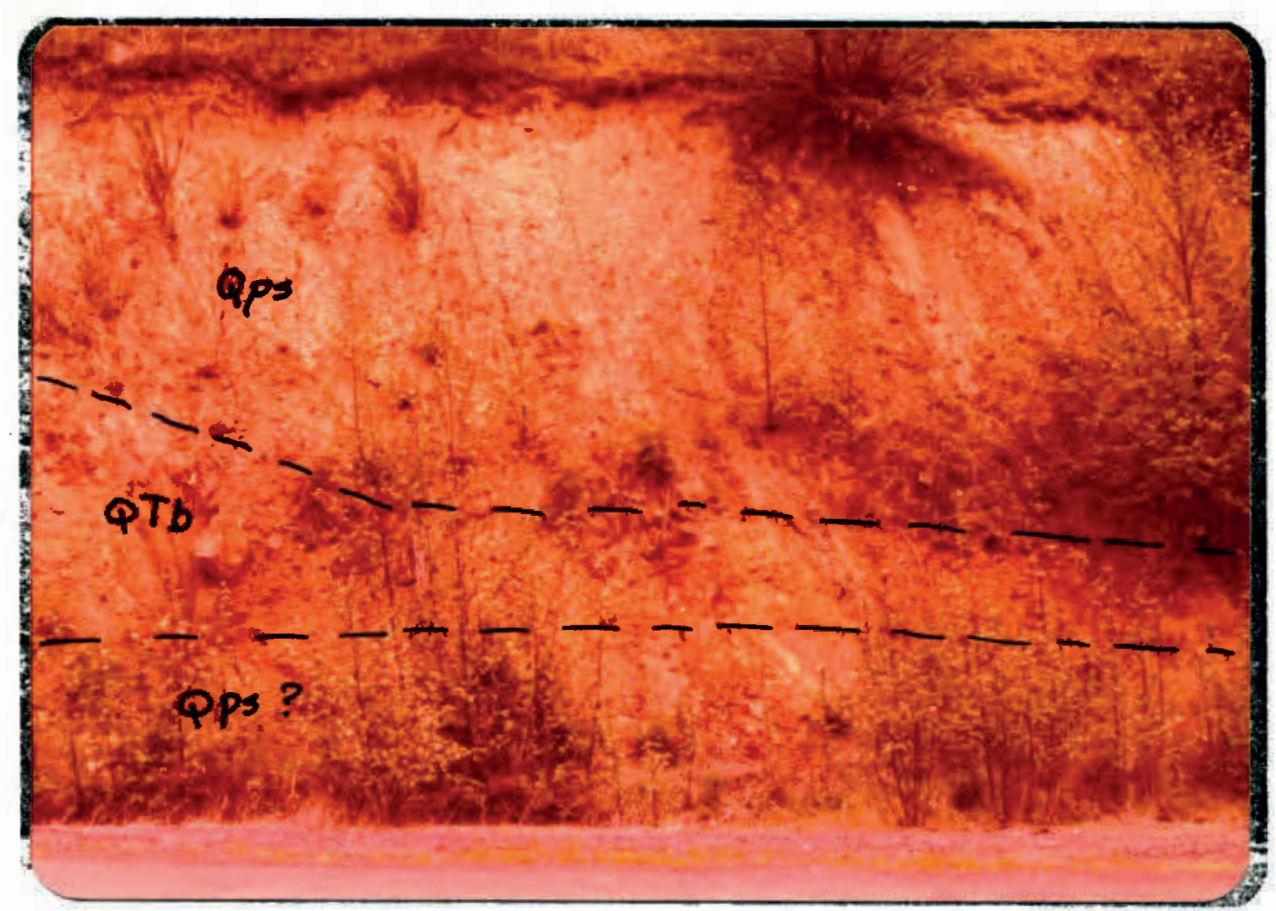

Figure 30. Road cut showing Boring Lava interstratified with the Portland Hills Silt, near the junction of SW Barnes and Miller Roads. 
Columbia Valley than in the Willamette Valley" (p. 205). The source for both water and sediment, he postulated, was a series of unusually large floods, like the "Spokane floods" described by Bretz and others (1956). Following deposition of the Willamette silt, a "climactic" flood of the same nature raised the valley water levels up to $122 \mathrm{~m}$ $(400 \mathrm{ft})$. It also scoured and reworked parts of the older silt and dropped widespread glacial erratics (p. 194). Carbon 14 age dates reported by Glenn ( $p$. 182) indicate that the Willamette Silt and postdepositional flood occurred between about 19,000 and 34,400 years B.P. Because the lithology of the Portland Hills Silt so closely resembles that of the Willamette Silt, their stratigraphic association has long been determined by indirect means. Sampling and analysis of Boring DAH76-1, however, gives evidence to confirm the superposition of the younger Willamette Silt.

Examination of that section (Figure 31, Appendix F) indicates a 1ithologic break at a depth of $3 \mathrm{~m}$. The presence of soil-like mottling and an increase of organic carbon and concretionary shot below the contact suggests a buried soil profile, or at least its remnants. The possibility that it represents the Willamette Silt/Portland Hills Silt interface is suspected because (1) the W1llamette silt should be present at the surface below elevations of 92-107 m (300-350 ft; Glenn, 1965, p. 141), and (2) the near surface textural characteristics of the Portland Hills Silt in other sections (Figures 32-36, Appendix F) do not match those of DAH76-1 (i.e., the clay content above $2.5 \mathrm{~m}$ is much higher in DAH76-1 than in the others).

To test the latter possibility, Willamette Silt samples from five 
2 m deep borings (below 250 ft elevations) were analyzed to determine the local textural and heavy mineral characteristics of the formation. Only ridgecrest sites were selected in order to avoid contamination by recent alluvium. These borings are designated WS76-1 to 5 (see Plate 1 for locations). One sample from each of the upper and lower zones in DAH76-1 was also analyzed for heavy mineral content and frequency, for comparison with the known formations.

The results of these analyses confirm a relatively high average clay content (about 29 percent) for the Willamette Silt. This contrasts with the 18 percent clay content for Portland Hills Silt taken at the same depth in nearby DAH76-2, and the 19 percent average for 67 uniform depth Portland Hills Silt samples (Table 4). In addition, the hornblende content in DAH76-1 increases from the upper to lower unit (Table 11), a situation exactly the reverse of what might be expected in a normal Portland Hills Silt section (see p. 100).

The data suggest that in DAH76-1, the typically high-hornblende, low-clay surface unit of the Portland Hills Silt has been partially eroded and subsequently buried by the low-hornblende and high-clay Willamette Silt formation. The greater percentage of hornblende in the Willamette Silt of DAH76-1 may be due to contamination from the adjacent Portland Hills Silt.

The relationships in DAH76-1 imply Willamette Silt deposition above $84 \mathrm{~m}(275 \mathrm{ft})$ and probably up to $92-99 \mathrm{~m}(300-325 \mathrm{ft})$ about the Tualatin Valley margin. 
TABLE 11

COMPARISON OF HEAVY MINERALS IN DAH76-1

TO THOSE IN PORTLAND HILLS SILT

AND WILLAMETTE SILT

\begin{tabular}{|c|c|c|c|c|}
\hline MINERALS & $\begin{array}{c}\text { WS } \\
\text { AVERAGE }^{1} \\
\end{array}$ & $\begin{array}{c}\text { UPPER ZONE } \\
\text { DAH 76-1b }\end{array}$ & $\begin{array}{c}\text { LOWER ZONE } \\
\text { DAH76-1f }\end{array}$ & $\begin{array}{c}\text { PHS } \\
\text { AVERAGE } 2 \\
\end{array}$ \\
\hline Hornblende & 55 & 71 & 112 & 82 \\
\hline Lamprobolite & 8 & 6 & 7 & 5.3 \\
\hline Tremolite & 1 & 1 & 1 & 2 \\
\hline Actinolite & -- & - & -- & 0.1 \\
\hline Augite & 24 & 18 & 18 & 20 \\
\hline Hypers thene & 1.8 & 1 & 1 & 1.1 \\
\hline Epidote Group & 29.4 & 32 & 19 & 30 \\
\hline Garnet & 1.4 & 2 & $\mathrm{~T}$ & 2.7 \\
\hline Sphene & $\mathbf{T}$ & - & -- & 0.4 \\
\hline Zircon & 0.6 & 1 & 3 & 1.8 \\
\hline Kyanite & $\mathbf{T}$ & -- & 2 & 0.6 \\
\hline Tourmaline & $\mathbf{T}$ & 1 & 1 & 0.6 \\
\hline Pyrophy 111 te & $\mathrm{T}(?)$ & $\mathrm{T}(?)$ & $T(?)$ & $\mathrm{T}(?)$ \\
\hline Staurolite & -- & -- & $-\infty$ & 0.4 \\
\hline Andalusite & -- & - & - & $\mathbf{T}$ \\
\hline Sillimanite & -- & -- & -- & 0.1 \\
\hline Monazite & 0.1 & -- & - & 0.4 \\
\hline Mica Group & 9 & 10 & -- & 6.4 \\
\hline Apatite & 0.4 & - & -- & 0.4 \\
\hline Hemat1te & 21.2 & 23 & 14 & 12.8 \\
\hline Leucoxene & 5.6 & 5 & 1 & 3.7 \\
\hline Magnetite/I1menite & 26.4 & 13 & 15 & 17.4 \\
\hline Rock Fragments & 6.4 & 6 & 3 & 4.1 \\
\hline Volcantc Glass & 0.6 & 2 & 1 & 0.9 \\
\hline Others & 6.6 & 8 & 2 & 6.8 \\
\hline Tota1 & $\sim 200$ & 200 & 200 & $\sim 200$ \\
\hline
\end{tabular}

${ }^{1}$ See Appendix $\mathrm{C}$.

2 From Table 8. 
STRATIGRAPHY OF THE PORTLAND HILLS SILT

\section{Distribution and Thickness}

Tualatin Mountains. The distribution of the Portland Hills Silt in the Tualatin Mountain area is shown in Plate 1. Though micaceous Portland Hills Silt appears almost to be a universal soil constituent over the entire region--even residual soils derived from Columbia River Basalt or Boring Lava contain scattered flecks of mica in their surface horizons--only areas displaying more than $0.5 \mathrm{~m}$ of the material are mapped.

The silt typically mantles flatter ridge crests and slopes above approximately $152 \mathrm{~m}$ (500 ft) elevation on the eastern flank of the mountains, but locally extends down to 60-92 m (200-300 ft) on some spurs. Along NW McName Rd., NE 1/4, sec. 19, T.2N., R.2W., and NW Newberry Rd., NW 1/4, sec. 33, T.2N., R.2W., for example, Portland Hills Silt is present down to $60 \mathrm{~m}(200 \mathrm{ft})$ and $84 \mathrm{~m}(275 \mathrm{ft})$ respectively. Presumably, remnants of the formation are present even below these elevations where they may or may not be covered by younger alluvium. The silt is present up to $366 \mathrm{~m}$ (1200 ft) on the crest of the mountains.

Micaceous sediments of the Portland Hills Silt are more extensive on the broader, western flank of the mountains. However, the more abrupt hill slopes and valley walls have been stripped of the deposit. The silt extends down to about 92-107 m (300-350 ft) in elevation, at which point it is generally overlain by wllamette silt or younger stream alluvium. Because it is covered, the total westward extent of 
the deposit into the Tualatin basin is unknown.

Information concerning the total depth of the Portland Hills Silt and its geographic variation is extremely limited, mainly because of the small number of outcrops which expose the base of the formation. To add to the problem, the silt often displays considerable local variations in depth, which are largely dependent upon topography. Assorted data sources, however, indicate a gross thinning of the deposit westward. Two deep holes drilled just above Washington Park show at least $37 \mathrm{~m}(121 \mathrm{ft})$ and $23 \mathrm{~m}(75 \mathrm{ft})$ of "brown" and "reddishbrown" silt, which is interpreted as Portland Hills Silt. The holes were drilled for the Portland City Water Bureau and are located at $220 \mathrm{~m}(720 \mathrm{ft})$ and $223 \mathrm{~m}(730 \mathrm{ft})$ in elevation respectively (Dianne Parch, personal communication, 1977). Similarly, a deep well drilled on private property near sample site 76-112, SE 1/4 NE 1/4, sec. 19, T.2N., R.1W., in the northeast part of the map, indicates $37 \mathrm{~m}(120 \mathrm{ft})$ of "mud" above "bedrock" (personal communication with owner, 1976). Part of this section may include weathered basalt or Helvetia sediments. Its maximum elevation is $152 \mathrm{~m}$ (500 ft).

Further west, on the summit of the Tualatin Mountains, residents indicate between $18-27 \mathrm{~m}(60-90 \mathrm{ft})$ of "clay" above Columbia River Basalt. These wells are located in the middle part of the map area, between NW Cornell Rd. and NW Germantown Rd. Their data correlates well with the $17 \mathrm{~m}$ (55 ft) maximum thickness reported by Trimble (1963, p. 51) in that area, and the $13.7 \mathrm{~m}$ (45 ft) plus depth in DAH76-6 (see Figure 35, Appendix F).

The silt is generally less than $15 \mathrm{~m}(50 \mathrm{ft})$ and of ten less than 
$6 \mathrm{~m}(20 \mathrm{ft})$ thick in outcrops on the western flank of the mountains. Three borings reported by Hart and Newcomb (1965) in this region show somewhat thicker deposits of "soil and mantle undifferentiated," which overlie Boring Lava. Two of the holes (1N/1W-35M1 and $1 \mathrm{~N} / 1 \mathrm{~W}-35 \mathrm{Al}$ ) are located on a ridgecrest adjacent to NW Cornell Rd., sec. 35, T.1N., R.1W. The third $(1 \mathrm{~N} / 1 \mathrm{~W}-2 \mathrm{OH} \mathrm{L})$ is situated to the north and west, near the intersection of NW Kaiser and Laidlaw Rds., SE 1/4, sec. 48, T.IN., R.IW. The borings show a decreasing thickness of Portland Hills Silt (with the possible inclusion of some weathered Boring rock) from east to west, as indicated by the following depths to bedrock: $25 \mathrm{~m}(82 \mathrm{ft})$, $21 \mathrm{~m}(70 \mathrm{ft})$, and $13 \mathrm{~m}(43 \mathrm{ft})$.

Outlying Regions. Reconnaissance carried out southwest of the Tualatin Mountains indicates minor thicknesses of Portland Hills Silt mantling the highlands in that area. A thin silt veneer, rarely more than $3 \mathrm{~m}(10 \mathrm{ft})$ deep, caps Cooper and Bull mountains and the northeast flank of the Chehalem Mountains. In the latter area, the silt appears much less extensive than was previously mapped by Schlicker and Deacon (1967).

Perhaps because of deeper weathering, or because of colluvial additions from underlying material, the silt in these areas tends to be more red in color. It is a moderate orangish-brown (IOYR 5/6) when moist, rather than the more typical moderate yellowish-brown (IOYR $4 / 4-5 / 4)$

North and northeast of the map area in Oregon, the silt occurs less extensively but with similar topographic relationships. It is generally absent at distances greater than $7.5 \mathrm{~km}(5 \mathrm{mi})$ from the 
Columbia River basin, although Schlicker and Deacon (1967) have mapped portions of the deposit around the northern margin of the Tualatin Valley. Theisen (1958, p. 30) indicates less than $3 \mathrm{~m}$ (10 ft) of silt west of Scappoose, Oregon. The silt stretches northward along the Columbia River almost to Clatskanie, where it apparently pinches out.

Brief reconnaissance along the Washington side of the river south of Kelso-Longview suggests that the Portland Hills Silt is essentially absent in that area. However, previous writers (Wilkinson, 1946, p. 26; Lowry and Baldwin, 1956, p. 12) have reported that lithologically similar deposits are locally present.

Portland Hills Silt was confirmed in the Gresham-Boring Hills region, east of Portland, but it is believed to be much less widespread than originally mapped by Trimble (1963). Recent construction cuts along the Mt. Hood Freeway reveal the deeply weathered Springwater formation, which is unmantled by younger sediments from SE Anderson Rd. eastward.

Thick, sandy and clayey silts, which are considered to be equivalent to the Tualatin Mountain deposits, were found as far east as Ross Mountain at an elevation of $366 \mathrm{~m}(1200 \mathrm{ft})$. The silt in this area is unlike its western hills counterparts and tends to be slightly orangish in color, more varied in texture (see p. 103, Equivalent Silts) and shows irregular, fine, blocky jointing.

Portland Hills Silt is not present on the highlands and mountains (including Petes Mountain) south of the Boring Hills and Lake Oswego. The areal distribution of the Portland Hills Silt in the greater Portland area is shown by the transparency in Figure 1. The map is 
modified from data reported by Theisen (1958), Trimble (1963), and Schlicker and Deacon (1967).

\section{Vertical and Areal Variation}

Textural Variation. A distinct fining of the Portland Hills Silt occurs from east to west, along the full length of the Tualatin Mountains. Plots of both the phi median and graphic mean (Folk, 1968, p. 45) of 20 widespread samples (those with complete granulometric analyses) reveal a decreasing grain-size trend from northeast to southwest, approximately perpendicular to the strike of the hills (Figure 37).

In order to include more data, sand-to-clay ratios of 67 samples were similarly plotted. The ratios varied substantially, however, even within local areas. To overcome these variations, caused possibly by depositional topography or slope aspect, reworking, or even misidentification of the silt, a technique of data averaging was employed. The mean of all sand/clay ratios within a radius of $2.5 \mathrm{~km}$ was plotted at each intersection point of a $2.5 \mathrm{~km}$ grid network (Figure 38).

Like that of the median and mean, the resultant map indicates a westward fining trend for the Portland Hills Silt. It is important to note, however, that the averaging technique gives only a general trend. Local deflections of the contours are not necessarily real.

The incongruities in the north part of the map may be attributed to (1) the limited number of data points or (2) deeper weathering of the Portland Hills Silt in this area.

Significant vertical textural variations are apparent in each of 


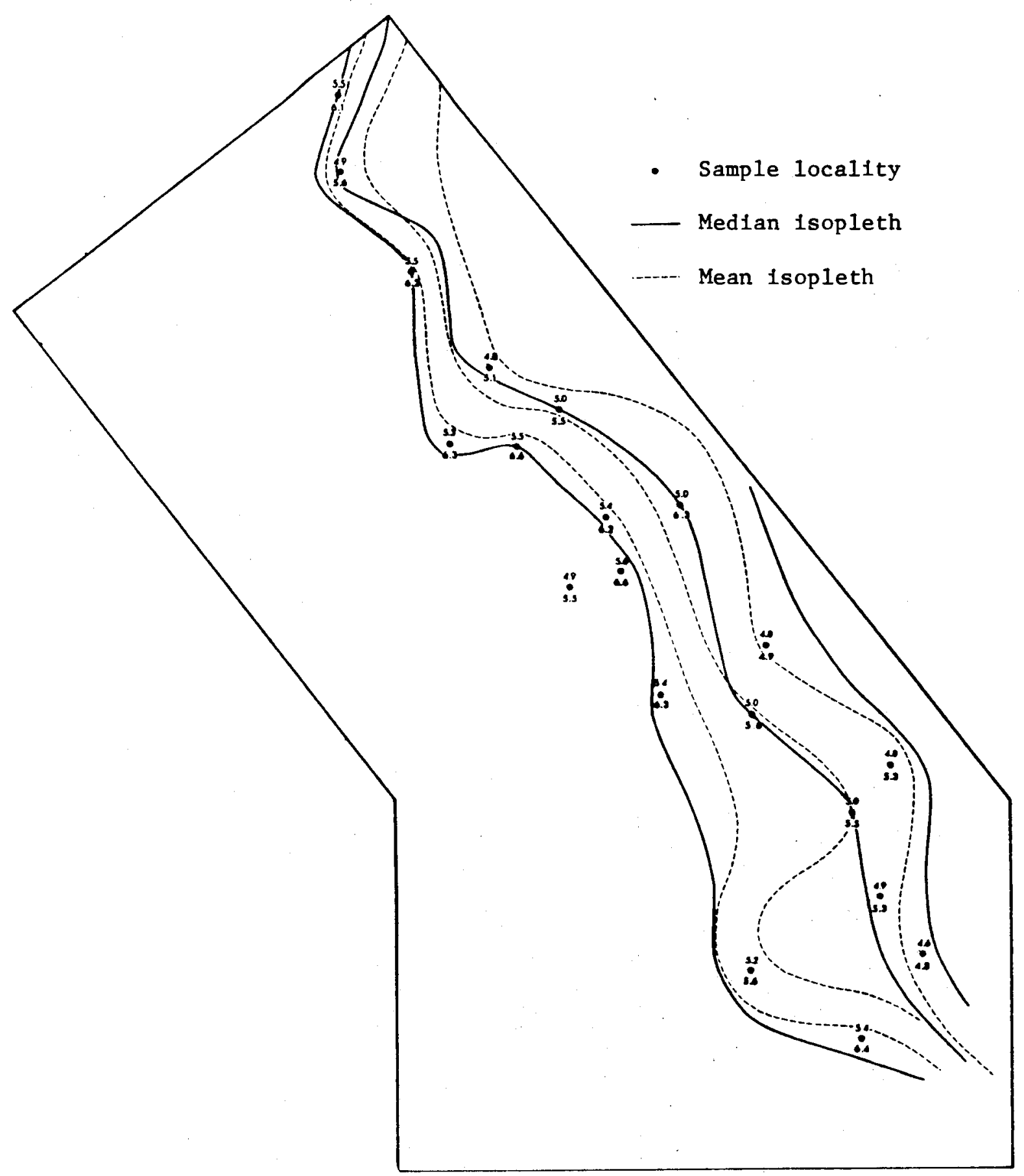

F1gure 37. Areal variation of the median (upper value) and mean (lower value) textural statistics in 20 Portland Hills Silt samples. 


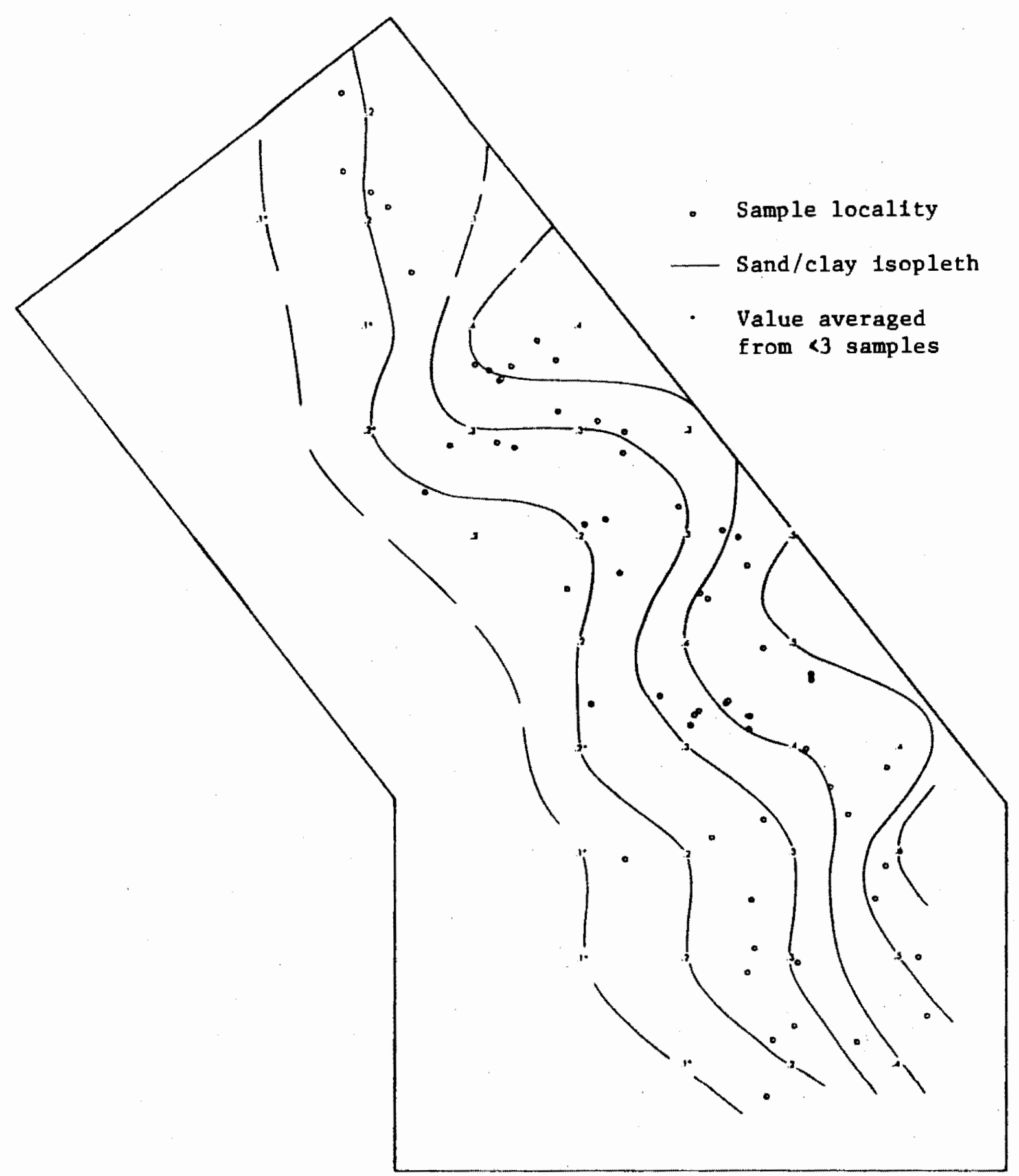

Figure 38. Areal variation of averaged sand/clay ratios from 67 Portland H111s silt samples. 
the six principal stratigraphic sections. The greatest differences, however, occur in the silt and clay percentages of DAH76-1 and DAH76-6. Silt and clay contents in DAH76-1 vary over a maximum range of 22.5 and 26.4 percentage points respectively, while in DAH76-6 both vary over a range of 21 percentage points. The remaining sections (DAH76-2, 3, 4, and the Skyline School section) show an average maximum range for silt and clay variation of only 12 percentage points.

The wider variance of the first two sections has been attributed to (1) the $3 \mathrm{~m}$ (10 ft) veneer of Willamette Silt which overlies Portland Hills Silt in DAH76-1, and (2) the presence of well developed paleosols in DAH76-6. Lesser textural variation in DAH76-4 and the Skyline School section can also be explained by visible paleosols. DAH76-2 and DAH76-3, however, show no evidence for a disruption in sedimentation. Vertical textural changes in these sections, therefore, may represent real fluctuations in the available energy of deposition or the deposit's source.

It is notable that any one of the variable depth samples, with the possible exception of those in the upper part of DAH76-1 and the lower part of the Skyline School section, fall easily within the 95 percent "size-range" depicted in Figure 17.

Compositional Variation. The light and heavy mineral grain counts listed in Tables 5 and 7 show considerable intrasample variation amongst these widely distributed samples. The data, however, show no recognizable geographic trends. Sample variation, therefore, is tentatively attributed to causes other than primary deposition. Inadequate staining is likely responsible for much of the 
variation in the light mineral fraction. Differences among the heavy mineral counts may be due, in part, to (1) conditions of weathering, (2) the inclusion of light mineral components (mica, rock fragments and volcanic glass) because of incomplete mineral separation, and (3) the stratigraphic position of the sample (see below).

Table 12 shows the variation with depth, of light and heavy minerals in DAH76-6. Five equally spaced samples represent unweathered silt from the uppermost silt layer (sample c), the second layer (f and 1), and the third (1) and fourth (o) layers (see Figure 35, Appendix F) .

The table shows a significant decrease in the total hornblende content and a corresponding increase of the augite and epidote for all samples below the surface unit. If this high-hornblende content is indeed characteristic of the youngest silt unit, it might explain the low hornblende values obtained from such uniform depth samples as 75-45 and 76-113 (see Table 7, page 66). Perhaps due to thinness or absence of the upper silt unit at these localities, a lower silt member was inadvertently sampled.

Light mineral constituents, particularly quartz and alkali feldspar, also appear to vary with depth. The magnitude of these fluctuations may be misleading, however, because of the possible counting errors due to incomplete staining.

Stratigraphic variations of mineral composition in the Portland Hills Silt, especially that of the heavy mineral suite, is indicative of subtle changes in the source area of the deposit, or perhaps simply a change in character or energy of the depositional currents. 
TABLE 12

LIGHT AND HEAVY MINERALS IN 5 VARIABLE DEPTH

PORTLAND HILLS SILT SAMPLES

FROM SECTION DAH76-6

\begin{tabular}{|c|c|c|c|c|c|}
\hline \multirow{3}{*}{ MINERALS } & \multirow{3}{*}{$\frac{\text { UNIT } 1 \text { (Top) }}{\text { DAH76-6c }}$} & SAMPLE & \multicolumn{2}{|c|}{ DES IGNATION } & \multirow{3}{*}{$\frac{\text { UNIT } 4}{\text { DAH76-6o }}$} \\
\hline & & \multicolumn{2}{|c|}{ UNIT 2} & \multirow{2}{*}{$\frac{\text { UNIT } 3}{\text { DAH76-61 }}$} & \\
\hline & & DAH76-6f & DAH76-61 & & \\
\hline \multicolumn{6}{|l|}{$\overline{\text { LIGHT MINERALS }}$} \\
\hline Quartz & 81 & 71 & 95 & 92 & 90 \\
\hline Chert & 2 & 5 & $\mathrm{~T}$ & 1 & 1 \\
\hline \multicolumn{6}{|l|}{ Alkali } \\
\hline Feldspar & 37 & 43 & 21 & 42 & 34 \\
\hline Plagioclase & 54 & 45 & 45 & 48 & 57 \\
\hline Volcanic Glass & 1 & 4 & 4 & 1 & 3 \\
\hline \multicolumn{6}{|l|}{ Acld Rock } \\
\hline Fragments & 5 & 6 & 3 & 3 & 4 \\
\hline \multicolumn{6}{|l|}{ Mafic Rock } \\
\hline Fragments & -- & -- & -- & -- & 1 \\
\hline Mica Group & 16 & 20 & 26 & 11 & 8 \\
\hline Others & 4 & 6 & 6 & 2 & 2 \\
\hline \multicolumn{6}{|l|}{ HEAVY MINERALS } \\
\hline Hornblende & 113 & 59 & 64 & 52 & 53 \\
\hline Lamprobolite & 2 & 1 & 3 & 4 & 1 \\
\hline Tremolite & 1 & 4 & 3 & 1 & 1 \\
\hline Actinolite & -- & 1 & -- & -- & -- \\
\hline Augite & 17 & 21 & 29 & 29 & 26 \\
\hline Hypersthene & -- & -- & -- & -- & -- \\
\hline Epidote Group & 22 & 35 & 34 & 30 & 35 \\
\hline Garnet & 2 & 1 & 2 & 3 & 1 \\
\hline Sphene & -- & -- & 1 & -- & 2 \\
\hline Zircon & -- & 2 & -- & 1 & 5 \\
\hline Kyanite & $\mathrm{T}^{*}$ & 1 & 2 & 3 & -- \\
\hline Tourmaline & 1 & 1 & 1 & 3 & -- \\
\hline Pyrophylite & $\mathrm{T}(?)$ & $\mathrm{T}(?)$ & $\mathrm{T}(?)$ & $\mathrm{T}(?)$ & $\mathrm{T}(?)$ \\
\hline Staurolite & -- & -- & -- & -- & -- \\
\hline Andalusite & -- & -- & -- & -- & -- \\
\hline Sillimanite & -- & -- & 2 & -- & -- \\
\hline Monazite & - & $\mathrm{T}$ & $\mathrm{T}$ & 1 & -- \\
\hline Mica Group & 8 & 16 & 12 & 8 & 13 \\
\hline Apatite & $\mathrm{T}$ & -- & $\mathrm{T}$ & 1 & -- \\
\hline Hematite & 10 & 17 & 18 & 26 & 18 \\
\hline Leucoxene & 1 & 5 & 5 & 8 & 4 \\
\hline Magnetite/Ilmenite & 19 & 23 & 11 & 13 & 29 \\
\hline Rock Fragments & 1 & 3 & 9 & 5 & 6 \\
\hline Volcanic Glass & 1 & 1 & 3 & 3 & $\mathrm{I}$ \\
\hline Others & 2 & 9 & 11 & 8 & 5 \\
\hline Total & 400 & 400 & 400 & 400 & 400 \\
\hline
\end{tabular}

*Minerals were noted but did not come under cross halrs during counting traverses. 


\section{Paleosols}

Character and Recognition. Criteria for the recognition of paleosols has been summarlzed by the Working Group on the Origin and Nature of Paleosols, established by the International Union for Quaternary Research (INQUA), Commission of Paleopedology (in Yaalon, 1971, pp. 153-158). They conclude that paleosols are best recognized by the B-horizon because the A-horizon is rarely preserved fully, and that more than one distinct pedogenic feature or diagnostic horizon must be present for a reliable identification. The most diagnostic features include: (1) Clayey and calcic horfzons or zones, (2) other pedogenic accumulations such as iron or silica rich crusts, concretions and various pans, and (3) bands of different color or structure. Because of its instability upon burial, organic matter content is less reliable than other criteria. When present, however, concentrations of organic carbon are generally considered indicative of pedogenesis.

Buried soils described in the Portland Hills Silt sections are identified on the basis of at least two, and usually three or more of the above criteria.

The paleosols, like their modern day counterparts, are invariably characterized by relatively darker reddish or brownish colored Bhorizons which show high clay contents (about $25-30$ percent). The horizons are commonly mottled, showing irregular patches of yellowishbrown and reddish or rust-orange material. They frequently show interconnected and, at depth, near vertical grayish streaks which represent 
relict blocky or prismatic jointing. Concretionary shot is comparatively abundant in the upper part of most profiles, as is organic carbon.

Total thickness of the buried soils varies from 0.6 to $2.4 \mathrm{~m}(2-8$ ft) and may indicate the extent of paleosol development and/or erosion prior to burial.

Morphological Variation. Like contemporary soils, the character of paleosols is commonly variable. Frye and Leonard (1951, p. 297) report that "the characteristics of profile morphology displayed by the Sangamon (a well known midwestern paleosol developed upon Illinoian loess and older deposits) have a wide range, even when considered from localities of similar situation."

The morphologies of paleosols in the Portland Hills Silt vary laterally within the horizon, or from one paleosol to another. Such features as color, jointing, thickness and contact relations may vary substantially in this manner. The variations are attributed to local physical and chemical conditions active during development and burial of each profile.

The paleosols may appear unusually thick in some cases, because of the incorporation of landslide debris from higher slopes. Field observations indicate that most disrupted and aerated silt, whether due to natural or artificial processes, was more oxidized and reddish in color than undisturbed material. 


\section{PETROGRAPHIC COMPARISON OF EQUIVALENT}

AND SIMILAR SEDIMENTS

\section{EQUIVALENT SILTS}

During reconnaissance of the outlying Portland and Tualatin Valley region a number of samples resembling the Portland Hills Silt were obtained from deposits of similar lithology and stratigraphic position. The samples were subjected to partial granulometric and compositional analysis for comparison to their Tualatin Mountain counterparts. The results of these analyses are summarized in Table 13. Sample locations are noted in Figure 1 and further described in Appendix D.

All samples with the exception of 76-188 (Ross Mountain) and 76-185 (Chehalem Mountain) are petrographically and texturally indistinguishable from the Portland Hills Silt of the Tualatin Mountains. The Ross Mountain sample, though compositionally equivalent, has a rather high sand content compared to most Portland Hills Silt representatives. This may be a local phenomenon, however, because two adjacent samples (76-187, 76-189) show more reasonable textures. The variation may be due to local reworking and concentration of the coarser particles, or perhaps even primary deposition.

Sample 76-185, from the Chehalem Mountains, is texturally similar to the Portland Hills Silt but reveals low hornblende, epidote and augite, and high opaque mineral contents. The discrepancy is attributed to greater weathering because of the deposit's relative 
TABLE 13

PETROGRAPHIC COMPARISON OF EQUIVALENT PORTLAND HILLS SILT SEDIMENTS FROM THE OUTLYING PORTLAND-TUALATIN VALLEY REGION

\begin{tabular}{|c|c|c|c|c|c|c|c|c|c|}
\hline $\begin{array}{l}\text { MINERALS } \\
\text { OR TEXTURE }\end{array}$ & $76-190$ & $7^{6-18}$ & $76-188$ & $16-1^{8}$ & $16-19^{3}$ & $76-19$ & $\mathrm{AH}^{4}$ & $16-185$ & $\begin{array}{c}\text { PHS }{ }^{1} \\
\text { AVERAGE }\end{array}$ \\
\hline PERCENT SAND & 4.7 & 8.2 & 19.7 & 5.3 & 7.3 & 2.9 & 2.1 & 1.6 & 4.9 \\
\hline PERCENT SILT & 81.9 & 88.3 & 57.8 & 63.0 & 86.5 & 71.9 & 74.4 & 74.6 & 77.2 \\
\hline PERCENT CLAY & 13.4 & 3.5 & 22.5 & 31.7 & 11.2 & 25.2 & 23.5 & 23.8 & 18.9 \\
\hline \multicolumn{10}{|l|}{ LIGHT MINERALS } \\
\hline Quartz & 78 & -- & 74 & -- & 68 & -- & 98 & -- & 79.0 \\
\hline Chert & $\mathbf{T}$ & -- & 1 & -- & 2 & -- & 1 & -- & 2.4 \\
\hline Alkali Feldspar & 48 & -- & 45 & -- & 39 & -- & 34 & -- & 33.6 \\
\hline Plagloclase & 33 & -- & 56 & $-\infty$ & 63 & - & 33 & -- & 57.4 \\
\hline Volcanic Glass & 4 & - & 4 & - & 7 & -- & 7 & - & 5.2 \\
\hline Ac1d Rock Frags. & 15 & -- & 10 & - & 4 & - & 3 & - & 4.2 \\
\hline Mafic Rock Frags. & -- & -- & 1 & -- & -- & - & 1 & -- & 0.5 \\
\hline M1ca Group & 17 & -- & 8 & -- & 13 & -- & 19 & -- & 12.8 \\
\hline Others & 5 & - & 1 & -- & 4 & -- & 4 & -- & 5.2 \\
\hline \multicolumn{10}{|l|}{ HEAVY MINERALS } \\
\hline Hornblende & 104 & -- & 69 & -- & 84 & 77 & 65 & 41 & 82.0 \\
\hline Lamprobolite & 1 & -- & 2 & -- & 6 & 3 & 5 & 1 & 5.3 \\
\hline Tremolite & 1 & -- & -- & -- & 1 & $\mathrm{~T}$ & $\mathrm{~T}$ & -- & 2.0 \\
\hline Actinolite & -- & -- & - & -- & -- & -- & -- & - & 0.1 \\
\hline Augite & 23 & - & 17 & - & 21 & 8 & 16 & 2 & 20.0 \\
\hline Hypers thene & $\mathrm{T}$ & -- & -- & - & 6 & 1 & 1 & -- & 1.1 \\
\hline Epidote Group & 30 & -- & 26 & -- & 39 & 27 & 31 & 10 & 30.0 \\
\hline Garnet & 2 & -- & 2 & -- & 3 & 1 & 1 & 1 & 2.7 \\
\hline Sphene & $T^{*}$ & - & 1 & -- & - & -- & -- & -- & 0.4 \\
\hline Z1rcon & 1 & - & $\mathrm{T}$ & - & 1 & $\mathrm{~T}$ & 4 & 1 & 1.8 \\
\hline Kyanite & -- & - & -- & -- & $\mathrm{T}$ & $\mathrm{T}$ & 1 & -- & 0.6 \\
\hline Tourmaline & -- & -- & -- & - & 1 & - & $\mathrm{T}$ & - & 0.6 \\
\hline Pyrophyllite & $\mathrm{T}(?)$ & $\mathrm{T}(?)$ & $\mathrm{T}(?)$ & $\mathrm{T}(?)$ & $\mathrm{T}(?)$ & $\mathrm{T}(?)$ & $\mathrm{T}(?)$ & $\mathrm{Y}(?)$ & $\mathrm{T}(?)$ \\
\hline Staurolite & -- & -- & -- & -- & 1 & -- & -- & -- & 0.4 \\
\hline Andalusite & -- & - & -- & - & -- & -- & -- & -- & $\mathrm{T}$ \\
\hline Stllimantte & 1 & - & -- & -- & -- & - & 1 & -- & 0.1 \\
\hline Monazite & 2 & -- & $\mathrm{T}$ & - & - & 1 & -- & -- & 0.4 \\
\hline M1ca Group & 9 & -- & 8 & -- & 9 & 13 & 26 & $\mathbf{T}$ & 6.4 \\
\hline Apatite & 2 & -- & -- & - & $\mathrm{T}$ & -- & 1 & -- & 0.4 \\
\hline Hemat1te & 6 & -- & 29 & -- & 10 & 16 & 15 & 82 & 12.8 \\
\hline Leucoxene & 4 & -- & 3 & -- & 3 & 3 & 5 & 2 & 3.7 \\
\hline Magnetite/Ilmenite & 3 & -- & 32 & -- & 8 & 36 & 13 & 51 & 17.4 \\
\hline Rock Fragments & 6 & -- & 9 & -- & 3 & 4 & 3 & 3 & 4.1 \\
\hline Volcanic Glass & 1 & -- & 9 & -- & -- & 3 & 2 & 1 & 0.9 \\
\hline Others & 4 & - & 4 & -- & 4 & 7 & 10 & 5 & 6.8 \\
\hline Total & 400 & 400 & 400 & 400 & 400 & 400 & 400 & 400 & $\sim 400$ \\
\hline
\end{tabular}

*M1nerals were noted but did not come under cross hairs during counting traverses

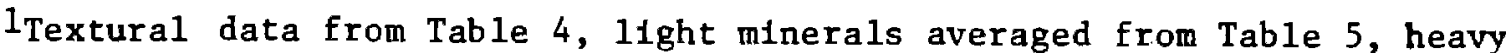
minerals from Table 8 . 
thinness ( $2 \mathrm{~m}$ ) at that locale, and possibly because of contamination from the underlying Helvetia formation.

SIMILAR DEPOSITS

Local

Lithologically similar deposits such as the Helvetia, Tualatin Valley-Troutdale equivalent and the Willamette Silt formations may be indistinguishable from one another and the Portland Hills Silt, in outcrops showing poor exposure. To aid in the identification of these units, preliminary textural and heavy mineral analyses were performed on a number of examples from each (Appendix C). Representative samples from the known deposits are designated by prefixing with the abbreviated formation name (e.g., WS76-2, HEL76-90, TT76-196). Sample locations are noted in Plate 1 or Figure 1 , and are further documented in Appendix D.

The results of the above investigation are summarized in Table 14. Examination of the textural data reveals a distinctly higher clay content for the Willamette Silt and Helvetia formations, and a greater percentage of sand in the Troutdale-equivalent sediments with respect to the Portland Hills Silt.

A comparison of the heavy mineral constituents among the formations indicates three important features: (1) A dramatic contrast with regard to heavy mineral frequencies between the Helvetia and the other formations--The proportions of hornblende, epidote, augite and other minerals in the Helvetia as compared to the other sediments, and the abundant amounts of authigenic iron, suggest that this may be due to 
TABLE 14

SUMMARY OF TEXTURE AND HEAVY MINERALS IN SIMILAR TUALATIN MOUNTAIN DEPOSITS ${ }^{1}$

\begin{tabular}{|c|c|c|c|c|c|}
\hline \multirow{2}{*}{$\begin{array}{c}\text { TEXTURE } \\
\text { AND } \\
\text { MINERALS } \\
\end{array}$} & \multirow{2}{*}{$\begin{array}{c}\text { PORTLAND } \\
\text { HILLS } \\
\text { SILT } \\
\end{array}$} & \multicolumn{2}{|c|}{ WILLAMETTE SILT } & \multirow{2}{*}{$\begin{array}{l}\text { TROUTDALE } \\
\text { TUALATIN } \\
\text { V. EQUIV. }\end{array}$} & \multirow{2}{*}{ HELVETIA } \\
\hline & & $\begin{array}{c}\text { Tualatin } \\
\text { Valley }\end{array}$ & $\begin{array}{c}\text { Willamette } \\
\text { Valley } \\
\end{array}$ & & \\
\hline Percent Grave 1 & -- & - & -- & -- & 0.01 \\
\hline Percent Sand & 4.9 & 0.9 & $6 * *$ & 22.3 & 6.6 \\
\hline Percent S11t & 77.2 & 70.3 & $61^{\star \star}$ & 54.4 & 58.6 \\
\hline Percent Clay & 18.9 & 28.7 & $33^{\star \star}$ & 17.8 & 34.7 \\
\hline Number of Samples & $(67)$ & (5) & $(52)$ & (4) & (8) \\
\hline \multicolumn{6}{|l|}{ HEAVY MINERALS (\%) } \\
\hline Hornblende & 41.0 & 27.5 & 39.0 & 27.0 & 5.8 \\
\hline Lamprobolite & 2.7 & 4.0 & 1.0 & 0.75 & 0.2 \\
\hline Tremolite & 1.0 & 0.5 & -- & -- & 0.3 \\
\hline Actinolite & 0.6 & -- & -- & -- & -- \\
\hline Augite & 10.0 & 11.6 & 7.4 & 18.7 & 1.5 \\
\hline Hypers thene & 0.5 & 0.8 & 7.7 & $0 / 5$ & -- \\
\hline Epidote Group & 15.0 & 14.2 & 8.8 & 14.5 & 1.5 \\
\hline Garnet & 1.3 & 0.7 & 0.8 & 1.0 & - \\
\hline Sphene & 0.2 & $\mathrm{~T}^{\star}$ & 0.7 & - & $-\infty$ \\
\hline Zircon & $\mathrm{T}$ & 0.3 & 0.4 & 0.5 & -- \\
\hline Kyanite & 0.3 & $\mathrm{~T}$ & 0.3 & 0.3 & $\mathbf{T}$ \\
\hline Tourmaline & 0.3 & $\mathrm{~T}$ & 0.3 & 0.5 & - \\
\hline Pyrophy111te & $\mathrm{T}(?)$ & $\mathrm{T}(?)$ & 0.1 & $\mathrm{~T}(?)$ & -- \\
\hline Staurolite & 0.2 & -- & $\mathbf{T}$ & 0.2 & -- \\
\hline Andalusite & $\mathrm{T}$ & -- & -- & -- & -- \\
\hline Sillimantte & $\mathrm{T}$ & -- & -- & - & -- \\
\hline Monazite & 0.2 & 0.3 & 0.1 & -- & -- \\
\hline Mica Group & 3.2 & 4.5 & 3.4 & 6.5 & 1.2 \\
\hline Apatite & 0.2 & 0.2 & $\rightarrow$ & $\mathrm{T}$ & -- \\
\hline Hemat 1 te & 6.4 & 10.6 & 1.3 & 6.3 & 55.5 \\
\hline Leucoxene & 1.8 & 2.8 & 3.8 & 3.0 & 2.2 \\
\hline Magnet1te/Ilmenite & 8.8 & 13.2 & 10.4 & 8.0 & 28.3 \\
\hline Rock Fragments & 2.1 & 3.2 & 36.7 & 7.3 & 1.5 \\
\hline Volcantc Glass & 0.5 & 0.3 & & 0.3 & 0.3 \\
\hline 0thers & 3.4 & 3.3 & 7.6 & 5.7 & 1.8 \\
\hline $\begin{array}{l}\text { Total } \\
\text { Number of Samples }\end{array}$ & $\begin{array}{r}100 \% \\
(17)\end{array}$ & $\begin{array}{l}100 \% \\
(3)\end{array}$ & $\begin{array}{r}100 \% \\
(22)\end{array}$ & $\begin{array}{c}100 \% \\
(2)\end{array}$ & $\begin{array}{c}100 \% \\
(3)\end{array}$ \\
\hline
\end{tabular}

*Average percentage is less than 0.1 .

**Glenn used slightly different textural boundarles (sand $>.074 \mathrm{~mm}$, s11t .074-.005 mm, clay $<.005 \mathrm{~mm})$. His sand, s11t and clay percentages are respectively, $1-4 \%$ larger, about the same, and $1-3 \%$ smaller than if analysed using the textural boundarles of this report.

loriginal data is listed in Appendices $B$ and D.

2Data from Glenn, 1965. 
the intense weathering of the formation; (2) the similarity of the heavy mineral suite among all of the deposits, even the Helvetia sediments; and (3) the marked deficiency of hypersthene in the Portland Hills Silt, Troutdale-equivalent and Tualatin Valley Willamette Silt, as compared to the latter's Willamette Valley counterpart. This may reflect the contributions of low-hypersthene sediments from the northwest Coast Range province (Van Atta, 1971) and, perhaps, the incorporation of reworked Troutdale and Portland Hills Silt into the younger Willamette Silts of the Tualatin Valley.

The lithology of these deposits, as determined by the present study and from data presented by Schlicker and Deacon (1967) and Glenn (1965), is shown in Plate 1. Table 15 describes their surficial character and lists the distinguishing features which served to identify the deposits at ambiguous sites. In addition, identification and mapping of these formations, especially the Troutdale, was aided by subsurface data (Clarke, 1904; Hart and Newcomb, 1965; Schlicker and Deacon, 1967) and by geomorphic expression.

\section{$\underline{\text { Regional }}$}

Previous workers (Treasher, 1942; Lowry and Baldwin, 1952; Howe 11, 1962; Trimble, 1963; Schlicker and Deacon, 1967) have suggested that the Portland Hills Silt is derived from the Columbia River drainage basin and have correlated it with the late Pliocene or early Pleistocene Palouse soil of eastern Washington. This latter deposit is discussed by Treasher (1925), Bryan (1927) and Lotspeich and Smith (1953). 
TABLE 15

NEAR SURFACE CHARACTER AND DISTINGUISHING FEATURES IN SIMILAR TUALATIN MOUNTAIN DEPOSITS

\begin{tabular}{|c|c|c|c|c|}
\hline & $\begin{array}{c}\text { PORTLAND } \\
\text { HILLS } \\
\text { SILT } \\
\end{array}$ & $\begin{array}{c}\text { TROUTDALE } \\
\text { TUALATIN VALLEY } \\
\text { EQUIVALENT } \\
\end{array}$ & $\begin{array}{l}\text { WILLAMETTE } \\
\text { SILT }\end{array}$ & HELVETIA \\
\hline $\begin{array}{c}\text { NEAR } \\
\text { SURFACE } \\
\text { CHARACTER }\end{array}$ & $\begin{array}{l}\text { Massive, uniform } \\
\text { texture } \\
\text { Moderate yellow- } \\
\text { brown }\end{array}$ & $\begin{array}{l}\text { Stratified, may } \\
\text { appear massive } \\
\text { with uniform } \\
\text { texture } \\
\text { Moderate yellow- } \\
\text { ish-brown or } \\
\text { brown }\end{array}$ & $\begin{array}{l}\text { Usually massive } \\
\text { with uniform tex- } \\
\text { ture } \\
\text { Brown and yellow } \\
\text { brown }\end{array}$ & $\begin{array}{l}\text { Massive } \\
\text { Mottled red or } \\
\text { reddish-brown }\end{array}$ \\
\hline $\begin{array}{l}\text { DISTINGUISHING } \\
\text { FEATURES }\end{array}$ & $\begin{array}{l}\text { Non-calcareous } \\
\text { Generally }<25 \% \\
\text { clay, <10\% sand } \\
\text { Dominate heavies, } \\
\text { Hb. Epi., Aug. } \\
\text { Low hypers thene } \\
\text { Common shot }\end{array}$ & $\begin{array}{l}\text { May be calcareous } \\
\text { Generally >10\% } \\
\text { sand } \\
\text { Dominate heavies, } \\
\text { Hb. Ep1., Aug. } \\
\text { Low hypersthene(?) } \\
\text { Uncommon shot }\end{array}$ & $\begin{array}{l}\text { May be calcareous } \\
\text { Generally > } 25 \% \\
\text { clay, locally } \\
\text { sandy } \\
\text { Dominate heavies, } \\
\text { Hb., Ep1., Aug. } \\
\text { High hypersthene } 1 \\
\text { Uncommon shot }\end{array}$ & $\begin{array}{l}\text { Oxidized red- } \\
\text { brown color } \\
>25 \% \text { clay, may } \\
\text { be sandy or } \\
\text { pebbly } \\
\text { Dominate heavies, } \\
\text { Opaques } \\
\text { Abundant shot }\end{array}$ \\
\hline & & & & \\
\hline
\end{tabular}

IWillamette Valley (Glenn, 1965) 
Petrographic studies of the lower Columbia River sediments done by Glenn (1965) and of the Palouse Soil by Lotspeich and Smith (1953) are summarized in Table 16. For comparison, heavy mineral frequencies in Portland Hills Silt and Willamette Silt are also listed.

The data shows that the heavy mineral suites are very similar for al1 of the deposits. A significant1y low hypersthene content (1ess than 2 percent), however, characterizes both the Palouse soil and the Portland Hills Silt, whereas the Willamette Silt and the lower Columbia River sediments show relatively large amounts of that mineral.

Glenn (1965, p. 61) noted a similar relationship between the lower Columbia River samples and those from the upper basin, Walla Wa11a and Yakima tributaries. Whetten and others (1969, p. 1161) 1ater substantiated an increasing amount of hypersthene from the upper to the lower parts of the Columbia River. He attributed its abundance in the lower Columbia to volcanic sediment contributions from the Cascade mountain range.

\section{Loess Deposits}

Discussions involving description and analysis of loess deposits worldwide are prolific in the literature of geology and soil science. More recent examples include work by Ruhe (1967), Smalley (1966, 1971), Schultz and Frye (1968), Pews (1968), Fehrenbacker (1973) and Ives (1973) .

Numerous writers (Di11er, 1892; Darton, 1915; Treasher, 1942a; Theisen, 1958; Trimble, 1963; Livingston, 1966; Sch1icker and Deacon, 1967; Beaulieu, 1971; Niem and Van Atta, 1973) have casually remarked, 
TABLE 16

COMPARISON OF HEAVY MINERAL PERCENTAGES

IN SIMILAR REGIONAL SEDIMENTS

\begin{tabular}{|c|c|c|c|c|}
\hline MINERALS & $\begin{array}{c}\text { PORTLAND } \\
\text { HILLS } \\
\text { SILT } \\
\end{array}$ & $\begin{array}{l}\text { WILLAMETTE } \\
\text { SILT }^{1}\end{array}$ & $\begin{array}{l}\text { COLUMB IA } \\
\text { RIVER } \\
\text { SEDIMENTS }{ }^{1} \\
\end{array}$ & $\begin{array}{l}\text { PALOUSE } \\
\text { SOIL }^{2}\end{array}$ \\
\hline Hornblende & 41.0 & 39.0 & 24.0 & $43.0 *$ \\
\hline Lamprobolite & 2.7 & 1.0 & 1.5 & -- \\
\hline Tremolite & 1.0 & -- & -- & -- \\
\hline Actinolite & 0.1 & -- & - & - \\
\hline Aug1te & 10.0 & 7.4 & 10.8 & -- \\
\hline Hypersthene & 0.5 & 7.7 & 6.4 & 1.0 \\
\hline Epidote Group & 15.0 & 8.8 & 19.6 & 12.0 \\
\hline Garnet & 1.3 & 0.8 & 3.0 & -- \\
\hline Sphene & 0.2 & 9.7 & 2.0 & -- \\
\hline Z1rcon & 0.6 & 0.4 & 0.5 & -- \\
\hline Kyanite & 0.3 & 0.3 & 0.3 & -- \\
\hline Tourmaline & 0.3 & 0.3 & 0.1 & -- \\
\hline Pyrophyllite & $\mathrm{T}(?)$ & 0.1 & $\mathrm{~T}$ & \\
\hline Staurolite & 0.2 & $\mathrm{~T}$ & 0.2 & -- \\
\hline Andalusite & $\mathrm{T}$ & $\mathrm{T}$ & $\mathrm{T}$ & -- \\
\hline Sillimante & $\mathrm{T}$ & -- & 0.6 & -- \\
\hline Monazite & 0.2 & 0.1 & 0.9 & -- \\
\hline Mica Group & 3.2 & 3.4 & 0.2 & -- \\
\hline Apatite & 0.2 & (?) & (?) & -- \\
\hline Hematite & 6.4 & 1.3 & 0.6 & 7 \\
\hline Leucoxene & 1.8 & 3.8 & 1.2 & $\{11.0$ \\
\hline Magnetite/Ilmenite & 8.8 & 10.4 & 14.6 & \\
\hline Rock Fragments & 2.1 & 367 & 3,4 & -- \\
\hline Volcantc Glass & 0.5 & ro.t & $3^{1.4}$ & -- \\
\hline Others & 3.4 & 7.8 & 12.1 & $31.6 * *$ \\
\hline
\end{tabular}

*Includes hornblende and tremolite.

**Includes clino-pyroxene, zircon, garnet tourmaline and mica. ${ }^{1}$ Glenn, 1965.

${ }^{2}$ Lotspeich and Smith, 1953. 
or vehemently espoused, upon the similarity between the Portland Hills Silt and eolian deposits, particularly the loess of the American midwest. Points of correlation have included the massive nature, uniform silty texture, color and near surface vertical jointing of the deposit. Some authors have also reported loess-like thinning (Theisen, 1958, p. 29; Trimble, 1963, p. 52) and fining (Theisen, 1958, p. 29) of the Portland Hills silt away from the Columbia River (its inferred source). In addition, Trimble (1963, p. 52) cited the "conformity of the silt mantle to preexisting topography" as evidence for eolian deposition. The present investigation confirms or supports each of the characteristics described and compared above. Moreover, new data indicate the following additional similarities between the Portland Hills Silt and its loessal counterparts: (1) Like surface textures of constituent particles (see page 57); (2) a marked conformity in grain size distributions, as illustrated by Figure 39; and (3) the existence and the morphology of paleosols in the silt (see Figures 4 and 5, pages 30 and 31). 


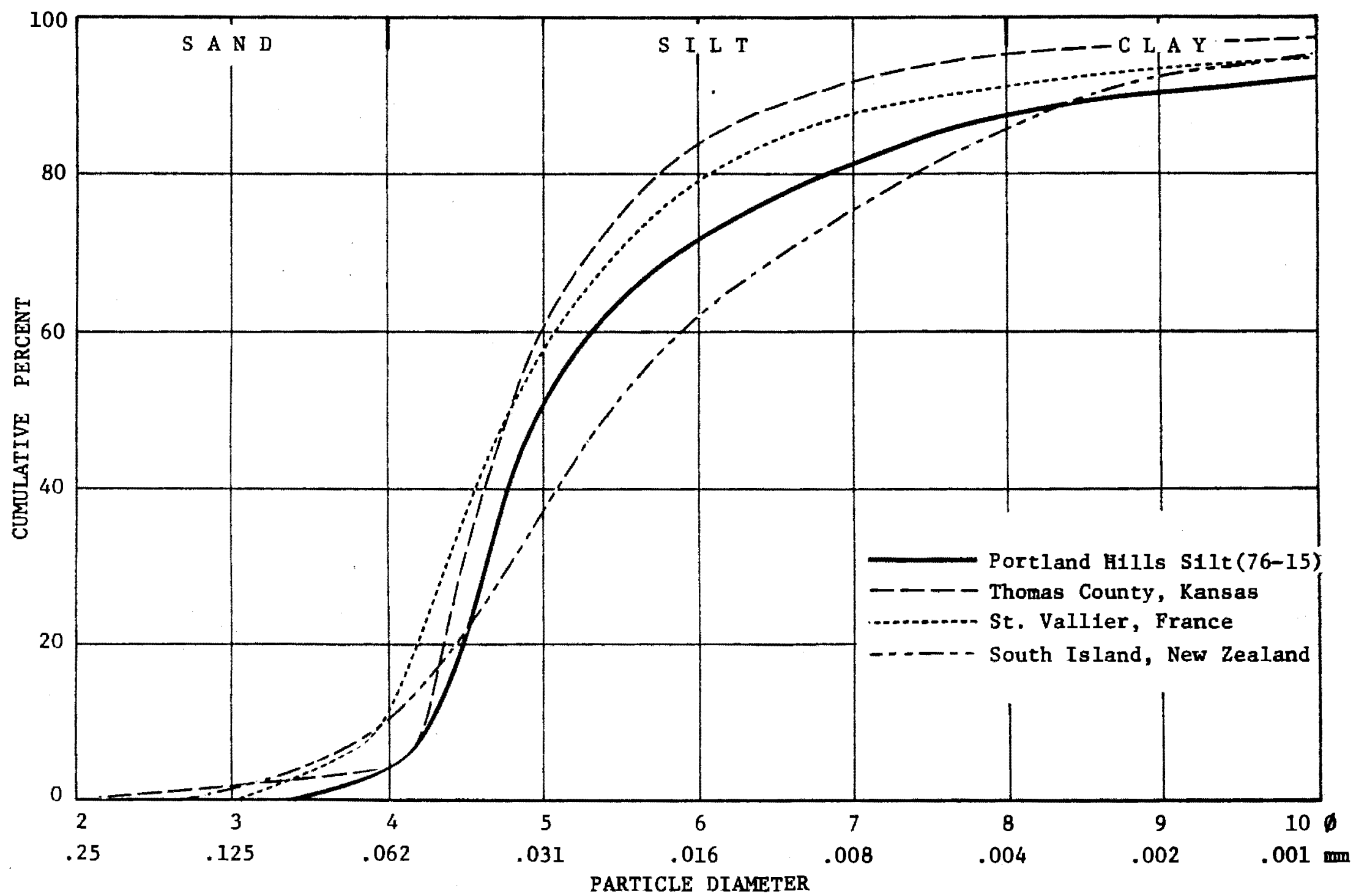

F1gure 39. Selected cumulative frequency curves from worldwide loess deposits (Swineford and Frye, 


\section{SUMMARY AND CONCLUSIONS}

NATURE OF THE DEPOSIT

The Portland Hills Silt is overlain by the Willamette Silt and underlain by the Boring Lava. Younger rocks of the Boring Lava, however, may be interstratified with the silt.

The Portland Hills Silt is, in outcrop, essentially a massive deposit. Nonetheless, deeper exposures may show up to four thick silt units, which are delineated by dark, reddish or brownish paleosols. Secondary structures such as concretionary shot and jointing are common and are associated with most surface and buried soil profiles. A few complex and apparently stratified exposures showing yellow-brown, reddish and/or gray colored silt are present locally. These are attributed to oxidation and deoxidation (gleying) processes related to groundwater circulation, particularly that connected with landsliding. Local disruption and aeration of the silt may also be responsible for apparent variations in color or weathering.

The formation shows remarkable uniformity both in color and texture. Unweathered silt is typically light yellowish-brown (10YR 6/46.5/4) when dry, and moderate yellowish-brown (10YR 4/4-5/4) when moist. Weathered material appears light to dark yellowish-orange (10YR 6/6-8/5) and moderate to dark reddish-brown or brown (5YR 5/56YR 4/6-10YR 5/2) respectively, when dry or wet. The average grain size distribution indicates 77 percent silt-, 19 percent clay- and 
5 percent sand-sized particles, very poor sorting and a fine skewed size distribution.

Vertical textural variations are minimal except where the sections are interrupted by paleosols, which have high clay percentages (25-30 percent). Geographically, a conspicuous fining trend is present from east to west, across the Tualatin Mountains: The median phi size decreases westward from 4.6 to 5.5 phi $(.041-.022 \mathrm{~mm})$.

Outsized clasts in the silt are rare and their presence is attributed to contamination from adjacent formations during accumulation or reworking of the deposit.

Portland Hills Silt is composed predominantly of sub-angular quartz (35\%) and feldspar (36\%), with lesser amounts of mica (6\%) and rock ditrius (3\%). Hornblende, epidote, augite and opaques constitute much of its heavy mineral suite, which also includes a variety of metamorphic species and very minor hypersthene. Clay minerals consist of montmorillonite or mixed-layer montmorillonite, illite and disordered kaolinite. Utilizing Folk's (1968) nomenclature for sedimentary rocks, the formation is classified as follows: Silt: micaceous immature subarkose.

The silt is largely distributed south and west of the Columbia River, where it mantles highlands above $92-152 \mathrm{~m}$ (300-500 ft) elevations. Below $92 \mathrm{~m}(300 \mathrm{ft})$ the deposit is either absent and presumably eroded off, or buried beneath younger sediments.

The depth of the silt decreases from approximately $37 \mathrm{~m}$ (120 ft) on the east side of the Tualatin Mountains to near zero in the Chehalem Mountains, a distance of about $27 \mathrm{~km}$ (18 mi). 
The Portland Hills Silt is remarkably similar in morphology, texture and distribution to loess deposits found in many parts of the world.

ORIGIN AND AGE

\section{Source}

Previous workers (Ruzek, 1922; Treasher, 1942; Wilkinson and others, 1946; Lowry and Baldwin, 1952; Theisen, 1958; Howell, 1962; Trimble, 1963; Schlicker and Deacon, 1967; Beaulieu, 1971) have long presumed that the Portland Hills Silt was derived from the Columbia River basin. The similarity in grain morphology (see p. 57), heavy mineral components and their frequencies in the Portland Hills Silt and the sediments of the Columbia River substantiate these views. Furthermore, minor hypersthene in the silt (see page 109) is suggestive of a contemporary, upper basin-type source, rather than that of the lower basin, which contains more hypersthene.

Portland Hills Silt, then, was derived largely from upper Columbia River provenance.

\section{Mode of Deposition}

The present investigation offers data which strongly supports a loessial origin for the Portland Hills Silt. As in previous works (Darton, 1915; Theisen, 1958; Trimble, 1963; Schllcker and Deacon, 1967), the concept is here based primarlly upon two major aspects of the deposit: its distributional character and 1ts striking physical resemblance to other loess deposits. 


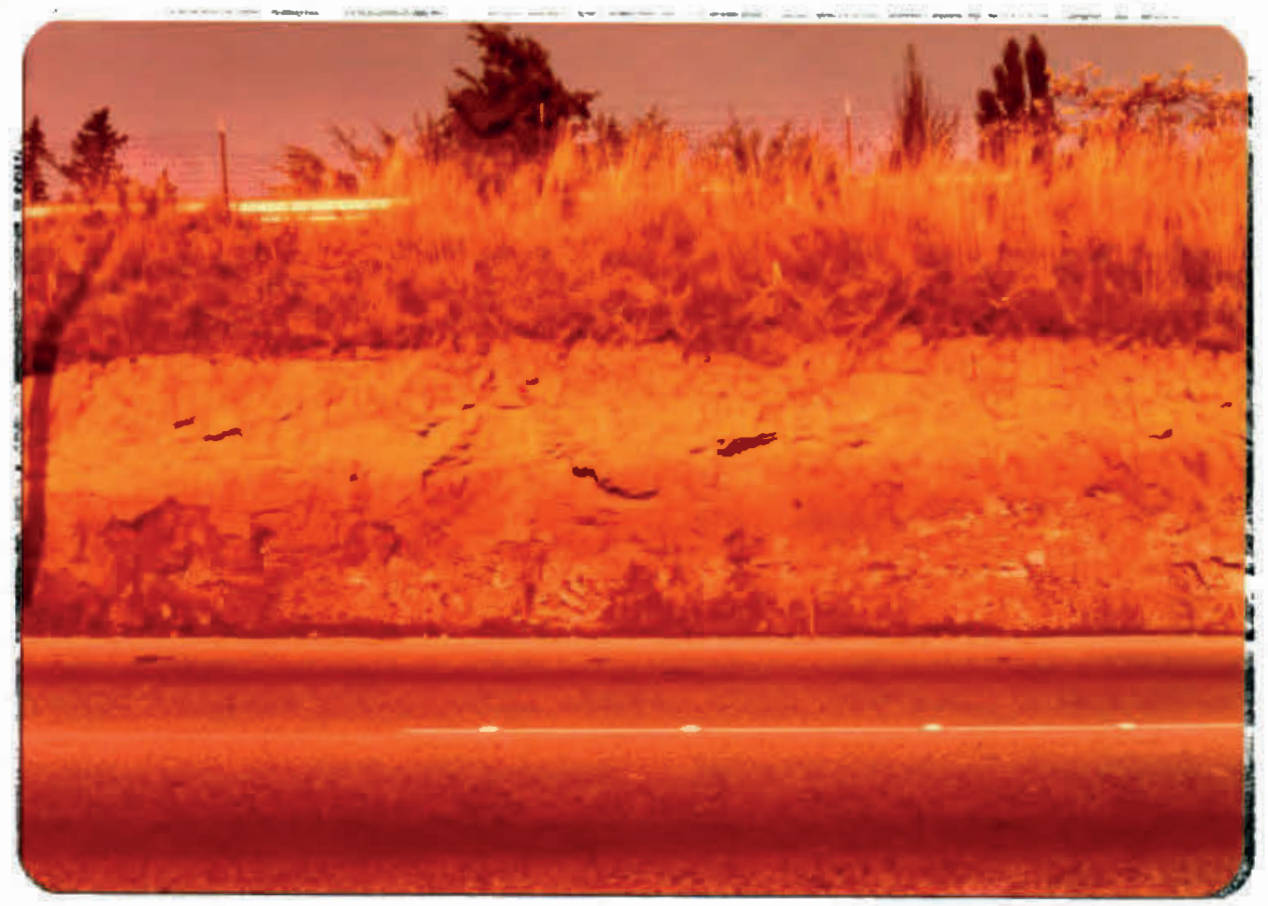

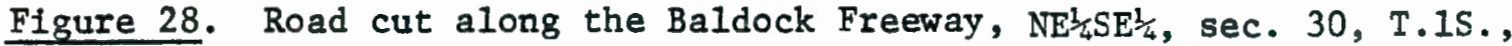
R.IE., showing Portland Hills Silt overlying weathered Boring Lava. Note the vertical, blocky jointing in the silt.

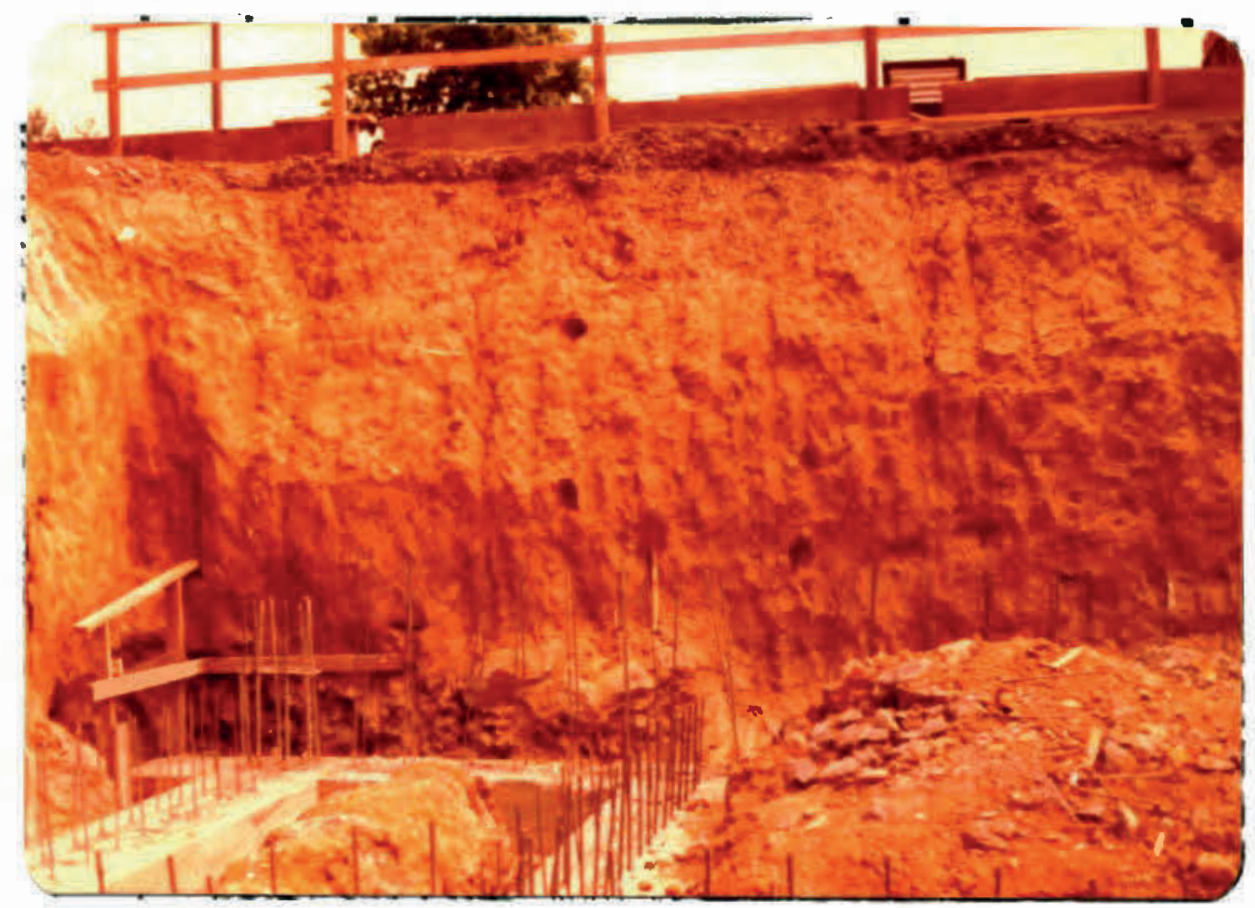

Figure 29. Construction cut at the St. Vircent Hospital (SW Barnes Road) showing Portland Hills Silt overlying Boring Lava. 
Many geologists agree that the Tualatin Mountains had formed alnost completely by Troutdale time (Lowry and Baldwin, 1952; Trimble, 1963; Hart and Newcomb, 1965; Beeson, Johnson and Moran, 1975). Evidence for this includes the following: (1) the absence of Troutdale gravels at the sumit or east of the mountains in the Tualatin Valley (Lowry and Baldwin, 1952, p. 10; Hart and Newcomb, 1965, p. 19);

(2) the apparent deflection of the Columbia River (Beeson, Johnson and Moran, 1975, p. 77); and (3) local thinning of stratigraphic units which indicates that initial folding probably began before Troutdale deposition, during outpouring of the Columbia River Basalts (Beeson, Johnson and Moran, 1975, p. 70).

Troutdale gravels once filled the Portland basin up to elevations of $183 \mathrm{~m}$ (600 ft; Hodge, p. 874) and probably $229 \mathrm{~m}(750 \mathrm{ft}$ ). This is evidenced by erosional remnants at Mt. Tabor and along the eastern flank of the Tualatin Mountains. The gravels were subsequently eroded off prior to deposition of the Portland Hills Silt, for it is unlikely that colluvial processes account for the occurrence of thick silt overlying Columbia River Basalt and Troutdale Formation on ridge spurs down to 61 or $92 \mathrm{~m}(200-300 \mathrm{ft})$ elevations. The Portland Hills Silt, then, was deposited in an environment of rather high relief, probably much like present day terrain.

If the silt were water-laid, regional subsidence (and/or eustatic rise in sea level) would certainly have been required. The deposit's massive nature suggests rapid deposition, such as during a flood. But only a catastrophic flood of unlikely proportions could possibly explain the thick silt deposits on the very crest of the mountains. 
On the other hand, the necessary rise in base level would presumably lay down $214 \mathrm{~m}$ (700 ft; Lowry and Baldwin, 1952, p. 11) or more of widespread lacustrine or fluvial silts. These would probably be very simflar to the stratified Tualatin Valley-Troutdale sediments. Selective erosion of such prominent deposits, particularly from the flat highlands south of Portland and from areas in Washington, is difficult to explain. The uniform texture and structureless nature of the silt, especially to depth, is also problematical. Furthermore, the presence of scattered pebbles, which are belleved to be colluvial additions, offer Insufficient evidence for a fluvial origin.

The Portland Hills Silt was more likely deposited by eolian processes. Dry easterly winds could have easily whipped up glacial outwash silts along the extensive flood plain of the Columbia River valley. Slowed by tree covered slopes, the wind would deposit the dust about the southwestern margin of the broad, Portland basin. East winds could also accrue lesser deposits in the adjacent hills north of the city. During accumulation of the silt, colluvial and alluvial processes would continue, adding coarser material from older, upslope deposits and locally reworking the silt. It is also likely that at lower elevations the eolian silt would be intertongued with water-laid sands and silts of the floodplain (this is represented as Qps' in Figure 25). Loess would collect fastest and to greater depths nearest its valley source. A corresponding decrease in grain size would accompany the leeward thinning of the deposit.

Though the prevailing surface winds of today are primarily westerlies (Highsmith, 1973, p. 43), thinning and fining of the Portland 
Hills Silt indicates that easterly or northeasterly winds were responsible for its deposition. These may have been the glacially stimulated anticyclones, as postulated by Theisen (1958, p. 59), intense pressure-gradient winds, like the easterly gorge winds of today, or perhaps a combination of these.

Age

The Portland Hills Silt must be older than the overlying Willamette silt formation and, for the most part, younger than the underlying Boring Lavas. Carbon 14 age dates reported by Glenn (1965, p. 182) indicate a maximum age for the willamette silt of about 34,400 years B.P.

Trimble (1963, p. 42) assigned a late Pliocene to late (?) Pleistocene age to the Boring Lava, on the basis of stratigraphy. Remnant magnetism of these basalts was recently studied by Burch (1977, personal communication). She found both normal and reversed polarities in samples from the Tualatin Mountains and around the Portland area. Since the Boring Lava is also overlain by the Willamette Silt, and because the Matuyama epoch is the first significant magnetic reversal older than that deposit ${ }^{1}$ (Figure 41), these lavas are, in part, probably at least as old; that is, 700,000 or more years B.P.

If the lower portion of the Portland Hills Silt is interbedded with the Boring Lava, it too may be as old. Deposition of the loess, then, probably occurred between approximately 34,000 and 700,000 (?)

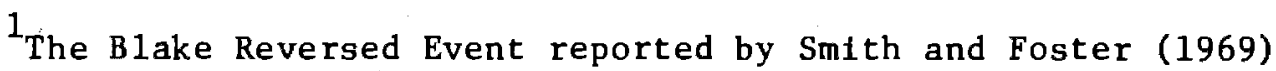
lasted only a very short time, 108,000-114,000 years B.P. 
years B.P., or in early to late Pleistocene time.

\section{CORRELATION}

Because of the paleosol's variable character, the lithologic similarity among silt members and, of course, poor exposure, correlation from one locality to another in the Tualatin Mountains is difficult. The fence diagram in Figure 40 shows a tentative correlation of the silt units in the principal sections, based upon their relative thickness and the development of their respective paleosols.

Quaternary paleosols are generally correlated with intervals of nonglaciation (Flint, 1971; Ruhe, 1967; Yaalon, 1971). For this reason it is suspected that the Portland Hills Silt units and their associated soils are correlative with glacial stages of the Pacific Northwest. Moreover, the relative thickness and development of the paleosols, as compared to the contemporary soils, suggest more than just incipient or short term weathering. Individual silt units, then, may be correlative to the major glacial episodes and their corresponding deposits, while their associated paleosols probably represent the intervening periods of nonglaciation.

Birkeland (1970) summarized the Quaternary stratigraphy of western Washington (Figure 41). He indicates four major glacial advances which are younger than 700,000 years B.P., but which predate the Olympia interglaciation (beginning 34,000 years B.P.). These are represented by the Orting Drift $(650,000$ years B.P.), the Stuck Drift ( 300,000 years B.P.) and the lower $(85,000$ years B.P.) and upper till (42,000 years B.P.) of the Salmon Springs Drift. The Portland Hills 


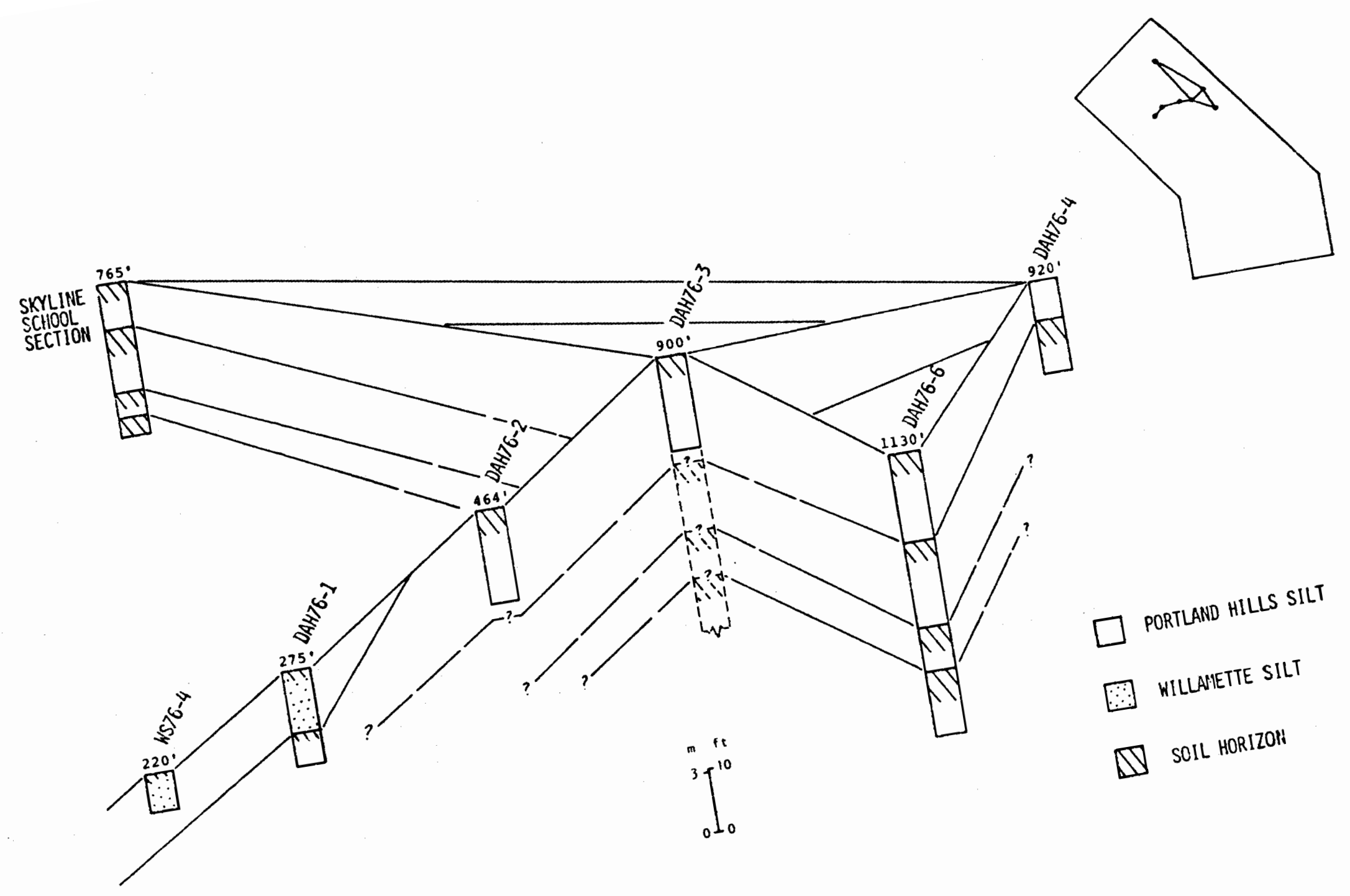

Figure 40. Correlation of subsurface data from the Tualatin Mountains. 
Silt units described in this paper may be directly correlative with these deposits.

The striking similarity in heavy mineral composition and frequency, and a like morphology, source and age, all imply a strong correlation between the Portland Hills Silt and the Palouse Soil of eastern Washington. However, while the lower part of the Portland Hills Silt may have been deposited simultaneously with the Palouse Soil, it is entirely possible, as suggested by Howell (1962, p. 18), that younger portions of the silt were derived from reworked and retransported Palouse material. 


\section{BIBLIOGRAPHY}

Allen, J. E., 1974, The Catlin Gabel lava tubes: Ore Bin, v. 36, p. 149-154.

Allison, I. S., 1935, Glacial erratics in the Willamette Valley: Geol. Sur. Amer. Bull., v. 46, p. 615-631.

American Commission on Stratigraphic nomenclature: A. A. P. G. Bull., v. 45 , p. 645-665.

Armstrong, J. E., and others, 1965, Late Plelstocene stratigraphy and chronology in southwestern British Columbia and northwestern Washington: Geol. Soc. Amer. Bul1., v. 76, p. 321-330.

Beaulleu, J. D., 1971, Geologic Formations of western Oregon: Oregon State Dept. Geol. Min. Inds. Bull., v. 70, 71 p.

Beeson, M. H., Johnson, A. G., and Moran, M. R., 1975, Portland environmental geology-fault Identification: Final Technical Report to: U. S. Geo1. Sur., 107 P.

Birkeland, P. W., Crandell, D. R., and Richmond, G. M., 1970, Status of correlation of Quaternary stratigraphic units in the western conterminous United States: Quat. Research, v. 1, p. 208-227.

Blakely, R. J., and Cox, A., 1972, Evidence for short geomagnet1c ploarity reversals in the early Cenozolc: Jour. Geophys. Res., v. 77, P. 7065-7072.

Bonhommet, N., and Zahringer, J., 1969, Paleomagnet1sm and potassium argon age determinations of the Laschamp geomagnetic polarity event: Earth and Planetary Sc1. Letters, v. 6, p. 43-46.

Bretz, H. J., Smlth, H. T. V., and Neff, G. E., 1956, Channeled scablands of Washington: New data and interpretations: Geol. Soc. Amer. Bull., v. 67, p. 957-1049.

Brown, G., 1961, The x-ray Identification and crystal structure of clay minerals: London, Mineralogical Soclety, 544 p.

Bryan, Kirk, 1927, The Palouse soll problem: U. S. Geol. Sur. Bull., v. 790B, P. 21-46.

Carver, R. E., 1971, Procedures in sedimentary petrology: New York, Wiley-Interscience, $653 \mathrm{p}$. 
Cegla, J., Buckley, T., and Smalley, I. J., 1971, M1crotextures of particles from some European loess deposits: Sedimentology, v. 17 , p. 129-134.

Clarke, D. D., 1904, A phenomenal landslide: Amer. Soc. Civil Engineers Trans., v. 53, p. 322-412.

Cox, Allan, 1969 Geomagnetic reversals: Sclence, v. 163, p. 237-245.

Crande11, D. R., Mullineaus, D. R., and Waldron, H. H., 1958, Pleistocene sequence in southeastern part of the Puget Sound Lowland, Washington: Amer. Jour. Sclence, v. 256, p. 384-397.

Culver, H. E., 1937, Extensions of the Ringold formation: Northwest Sci., v. 11, p. 57-60.

Darton, N. H., 1909, Structural materials in part of Oregon and Washington: U. S. Geol. Sur. Bull. 387.

Diller, J. S., 1896, A geological reconnalssance in northwestern Oregon: U. S. Geol. Sur. 17th Ann. Rept., pt. 1, p. 441-520.

Diller, J. S., and others, 1915, Guidebook of the western United States, pt. D, The Shasta route and coast 11ne: U. S. Geol. Sur. Bu11., v. 614 .

Doeglas, D. J., 1949, Loess, an eollan product: Jour. Sed. Petrology, v. 19 , p. 112-117.

Doeglas, D. J., 1952, Loess, an eollan product: Jour. Sed. Petrology, v. $22, \mathrm{p} .50-52$.

Easterbrook, D. J., 1969, Plelstocene chronology of the Puget Lowland and San Juan islands, Washington: Geol. Soc. Amer. Bull., v. 80 , p. 2273-2286.

Easterbrook, D. J., 1974, Late Plelstocene glaclal and paleomagnetlc events (abstr.): In Cordillerran section, 70th Annual Meeting, Geo1. Soc. Amer. Abstr., v. 6, p. 170-171.

Easterbrook, D. J., Crande1, D. R., and Leopold, E. B., 1967, PreOlympla Pleistocene stratigraphy and chronology in the central Puget Lowland, Washington: Geol. Soc. Amer. Bull., v. 78, p. 13-20.

Fehrenbacher, J. B., 1973, Loess stratigraphy, distribution, and time of deposition in Illinois: Soll Science, v. 115, p. 176-184.

Fenneman, N. M., 1931, Physiography of western United States: New York, McGraw-H111, 534 p. 
Flint, R. F., 1971, Glactal and Quaternary geology: New York, John Wiley and sons, $892 \mathrm{p}$.

Folk, R. L., 1968, Petrology of sedimentary rocks: Austin, Texas, Hemph111's, $170 \mathrm{p}$.

Folk, R. L., and Ward, W. C., 1957, Brazos River bar: A study in the significance of grain size parameters: Jour. Sed. Petrology, v. 27, p. 3-27.

Frye, J. C., and Leonard, B. A., 1951, Stratigraphy of the late Ple1stocene loesses of Kansas: Jour. Geol., v. 59, p. 287-305.

Glenn, J. L., 1965, Late Quaternary sedimentation and geologic history of the north Willamette Valley: Oregon State Ph.D. thesis, $231 \mathrm{p}$.

Grim, R. E., 1902, Clay mineralogy: New York, McGraw-H111, 384 p.

Hammond, P. E., 1975, Some radiocarbon dates in surficial deposits of the Portland area: Ore Bin, v. 37, p. 161-162.

Hart, D. H., and Newcomb, R. C., 1965, Geology and ground water of the Tualatin Valley, Oregon: U. S. G. S. Water Supply Paper 1697, $172 \mathrm{p}$.

Highsmith, R. M. Jr., 1973, Atlas of the Pacific Northwest: Corvallis, Oregon, Oregon State Univ. Press, $125 \mathrm{p}$.

Hobbs, W. A., 1931, Loess, pebble lands and boulders from glacla1 outwash of the Greenland Continental glacier: Jour. Geol., v. 39, p. 381-385.

Hodge, E. T., 1938, Geology of the lower Columbla River: Geol. Soc. Amer. Bul1. 49, p. 836-929.

Howe11, P. W., 1962, Depositional environment of the Portland Hills silt: Geol. Soc. Oregon Country News Letter, V. 28, p. 17-20.

Ives, David, 1972, Nature and distribution of loess in Canterbury, New Zealand: N. Z. Jour. Geol. and Geophys., v. 16, p. 587-610.

Kerr, P. F., 1959, Optical Mineralogy: New York, McGraw-H111, 442 p.

Kleiss, H. J., 1973, Loess distribution along the I11inots sol1 deve1opement sequence: Soll Sclence, v. 115, p. 194-198.

Krinsley, D., and Margolls, S., 1969, A study of quartz sand grain surfaces with the scanning electron microscope, Trans. New York Acad. Sc1., v. 31, p. 457-477.

Krumbe1n, W. C., 1938, Manual for sedimentary petrography: New York, D. Appleton-Century Co., 549 p. 
Krumbein, W. C., and Grayb111, F. A., 1965, An introduction to statistical models in geology: New York, McGraw-H111, 475 p.

Krumbein, W. C., and F. J. Pettifohn, 1938, Manual of sedimentary petrography: New York, Appleton-Century-Crofts, 549 p.

Krumbein, W. C., and Sloss, L. L., 1963, Stratigraphy and sedimentation: San Francisco, F. W. H. Framan and Co., 650 p.

Libbey, F. W., Lowry, W. D., and Mason, R. S., 1944, Preliminary report on high alumina iron ores in Washington County, Oregon: Oregon Dept. Geol. Min. Inds. short paper 12 .

Libbey, F. W., Lowry, W. D., and Mason, R. W., 1945, Ferruginous bauxite deposits in northwestern Oregon: Ore. Dept. Geol, and Min. Inds., Bu11. 29.

Livingston, V. E. Jr., 1966, Geology and mineral resources of the KelsoCathlamet area, Cowlitz and Wahklakum Counties, Washington:

Wash. Div. of Mines and Geol. Bull. 54, $110 \mathrm{p}$.

Lotspe1ch, F. B., and Smith, H. W., 1953, So1ls of the Palouse loess: I. The Palouse cantena: Soll Sc1., v. 76, p. 467-480.

Lowry, W. D., and Baldwin, E. M., 1952, Late Cenozolc geology of the Lower Columbla River Valley, Oregon and Washington: Geol. Soc. Amer. Bull., v. 63, p. 1-24.

Matalucc1, R. V., Shelton, J. W., and ABDEL-Hady, M., 1969, Grain orlentation in the Vicksburg loess: Jour. Sed. Petrology, v. 39, p. 969-979.

Mendenha11, W., 1971, Introduction to probab1l1ty and statistics: Belmont, Calif., Duxbury Press, 466 p.

Merriam, J. C., and Buwalda, J. P., 1917, Age of strata referred to the Ellensburg formation in the White Bluffs of the Columb1a River: Univ. Cal1f. Publs. Bu11., Dept. Geol., v. 10, p. 255-266.

M1lner, H. B., 1962, Sedimentary Petrography, (volume 1): New York, MacMilian Co., 643 p.

Müller, German, 1967, Part I: Methods in sedimentary petrology: New York, Hafner Publishing Co., 283 p.

Niem, A. R., and Van Atta, R. 0., 1973, Cenozolc stratigraphy of northwestern Oregon and adjacent southwestern Washington, In Beaulleu, J. D., ed., Geologic fleld trips in northern Oregon and southern Washington: Oregon State Dept. Geol. Min. Inds. Bu11., v. 77, p. 75-132. 
Pettijohn, F. J., 1975, Sedimentary rocks, 3rd Ed.: New York, Harper and Row, $628 \mathrm{p}$.

Powers, M. C., 1953, A new roundness scale for sedimentary particles: Jour. Sed. Petrology, v. 23, p. 124-135.

Raeside, J. D., 1964, Loess deposits of the South Island, New Zealand, and the solls formed on them: N. Z. Jour. Geol. Geophys., v. 7, p. 811-838.

Ruhe, R. V., 1969, Quaternary landscapes in Iowa: Ames, Iowa, Iowa State Un1v. Press, 255 p.

Ruzek, C. V., and Carpenter, E. J., 1922, Soll survey of Multnomah County, Oregon: Washington, Goverment Printing Offlce, 98 p,

Schlicker, H. G., and Deacon, R. J., 1967, Engineering geology of the Tualatin Valley region, Oregon: Ore. Dept. Geol. and Min. Inds. Bull. $60,88 \mathrm{p}$.

Schultz, C. B., and Frye, J. C., 1968, Loess and related eollan deposits of the world: Intern. Ass. Quaternary Research, 7 th Congress, Lincoln, Nebr. Untv., v. 12.

Shannon and Wilson Inc., 1969, F1nal report OMSI-Zoo landslide Investigation, Portland, Oregon: Unpubl. report.

Smalley, I. J., 1966, The properties of glacial loess and the formation of loess deposits: Jour. Sed. Petrology, v. 36, p. 669-676.

Sma1ley, I. J., 1971, "In situ" theories of loess formation and the signiflcance of the calcium-carbonate content of loess: Earth Sc1. Review, v. 7, p. 67-85.

Smalley, I. J., and Gabrera, J. G., 1970, The shape and surface texture of loess particles: Geol. Soc. Amer. Bu1l., v. 81, p, 15911595.

Smalley, I. J., and others, 1973, Obervations on the Ka1sertah1 Loess: Geol. Mag., v. 110, p. 29-35.

Smlth, J. D., and Foster, J. H., 1969, Geomagnet1c reversals in Brunhes Normal Polarity Epoch: Sclence, V. 163, p. 565-567.

Snaveley, P. C., Jr, and Wagner, H. C., 1963, Tertiary geolog1c history of western Oregon and Washington: Wash. State Div. Mines and Geol., Report of Investigations, no. 22 .

Swineford, A., and Frye, J. C., 1951, Petrography of the Peoria loess in Kansas: Jour. Geol., v. 59, p. 306-322. 
Swineford, A., and Frye, J. C., 1955a, Petrographlc comparison of some loess samples from western Europe with Kansas loess: Jour. Sed. Petrology, v. 25, p. 3-23.

Swineford, A., and Frye, J. C., 1955b, Stratigraphy of the late Pleistocene loess In Kansas: Jour. Geol., v. 59, p. 287-305.

Terugg1, M. E., 1957, The nature and ortgin of Argentina loess: Jour. Sed. Petrology, v. 27, p. 323-332.

Theisen, A. A., 1958, Distribution and character of loess-11ke soll in northwestern Oregon: Oregon State Univ, master's thesis, unpub1., $5 \mathrm{p}$.

Treasher, R. C., 1925, Origin of the loesses of the Palouse Region, Washington: Science, v. 61,469 p.

Treasher, R. C., 1942a, Geologic h1story of the Portland area: Ore. Dept. of Geol. and Min. Inds. GMI short paper, no. 7.

Treasher, R. C., 1942b, Geologic map of the Portland area: Ore. Dept. of Geol. and Min. Inds. Map.

Trimble, D. E., 1963, Geology of Portland, Oregon and adjacent areas: U. S. Geol. Sur. Bu11. 1119 .

Tuck, R., 1938, The loess of the Matanuska Valley, Alaska: Jour. Geol., v. 46, p. $647-653$.

Van Atta, R. 0., 1971, Sedimentary Petrology of some tertlary formations, Upper Nehalem River Basin, Oregon: Oregon State Univ. Ph.D. dissertation, unpub1., $245 \mathrm{p}$.

Warnke, D. A., 1971, The shape and surface texture of loess particles: Discussion: Geol. Soc. Amer. Bull., v. 82, p. 2357-2360.

Washburne, C. W., 1937, Tertlary strat1graphy of western Washington and northwestern Oregon: Univ. Washington, Pub. In Geol., v. 4, p. $1-266$.

Wheeting, L. C., 1963, Shot solls of western Washington: Sol1 Sc1., v. 41 , p. $35-45$.

Wilkinson, W. D., Lowry, W. D., and Baldwin, E. M., 1946, Geology of the St. Helens qradrangle, Oregon: Ore. Dept. Geol. and Min. Inds. Bu11. 31 .

W111lams, I. A., and Bretz, J. H., 1916, Columbla River Gorge; 1ts geologlc history interpreted from the Columbia River highway: Ore. Bur. of Mines and Geol., 130 p. 
Yaalon, D. H., 1971, Paleopedology: Origin, nature and dating of paleosols: Jerusalem, International Soc. of Soll Sc1. and Israel Univ. Press, $350 \mathrm{p}$.

Young, D. J., 1967, Loess deposits of the west coast of the South Island, New Zealand: N. Z. Jour. Geol. Geophys., v. 10, p. 647658. 


\section{APPENDIX A}

Flow Chart of Sample Analysis

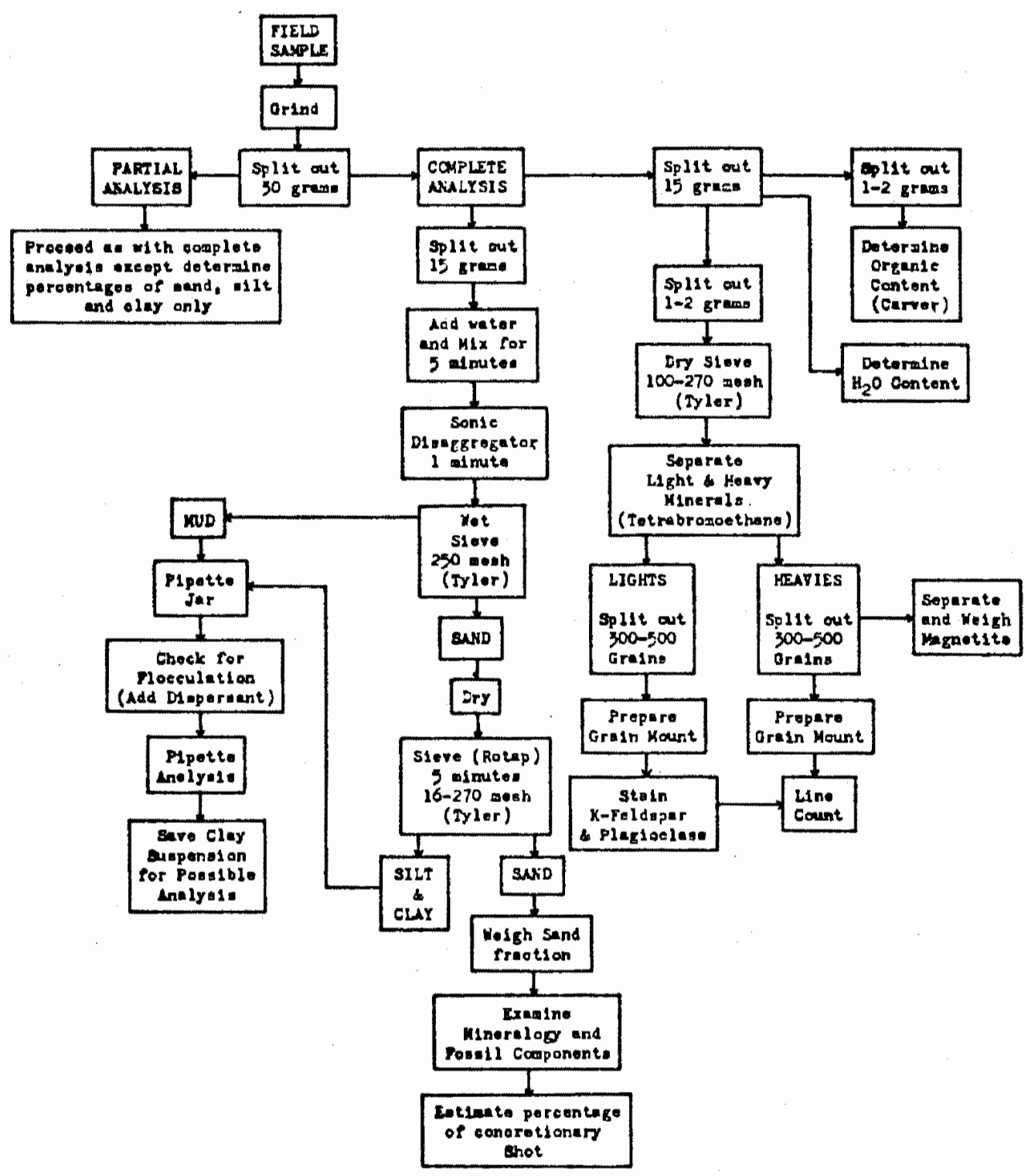




\section{APPENDIX B}

TABLE 17

GRANULOMETRIC STATISTICS FOR 20 PORTLAND HILLS SILT SAMPLES FROM WIDESPREAD TUALATIN MOUNTAIN SITES

\begin{tabular}{|c|c|c|c|c|c|c|c|c|c|c|}
\hline \multirow{2}{*}{$\begin{array}{l}\text { SAMPLE } \\
\text { NUMBER } \\
\end{array}$} & \multirow[b]{2}{*}{ MODE } & \multirow[b]{2}{*}{ MEDIAN } & \multicolumn{4}{|c|}{ FOLK AND WARD } & \multicolumn{4}{|c|}{ MOMENT MEASURES } \\
\hline & & & MEAN & SORTING & SKEWNESS & KURTOSIS & MEAN & S. DEV. & SKEWNESS & KURTOSIS \\
\hline $75-33$ & 4.3 & 5.38 & 6.27 & $2.57 *$ & $0.64 *$ & $1.22 \star$ & 6.46 & 2.65 & 1.22 & 3.52 \\
\hline $75-41$ & 4.5 & 5.20 & 5.62 & $1.81 *$ & $0.53 *$ & $1.49 *$ & 5.85 & 2.06 & 1.82 & 6.20 \\
\hline $75-45$ & 4.7 & 5.36 & 6.45 & $2.55 \star$ & $0.66^{\star}$ & $1.19 *$ & 6.50 & 2.71 & 1.07 & 3.24 \\
\hline $75-83$ & 4.5 & 4.84 & 5.15 & 1.17 & 0.53 & 1.63 & 5.33 & 1.55 & 2.19 & 8.77 \\
\hline $76-7$ & 4.5 & 4.76 & 4.95 & 1.33 & 0.52 & 1.99 & 5.37 & 1.89 & 2.23 & 7.53 \\
\hline $76-15$ & 4.7 & 4.99 & 5.55 & $1.82 *$ & $0.66 *$ & $1.78 \star$ & 5.83 & 2.16 & 1.88 & 6.10 \\
\hline $76-17$ & 4.3 & 4.57 & 5.34 & 1.67 & 0.69 & 1.61 & 5.39 & 1.99 & 1.79 & 5.65 \\
\hline $76-29$ & 4.5 & 4.97 & 5.45 & $1.86 *$ & $0.61 *$ & $2.30 \star$ & 5.71 & 2.21 & 1.95 & 6.11 \\
\hline $76-32$ & 4.5 & 4.61 & 4.80 & 1.13 & 0.61 & 3.22 & 5.19 & 1.78 & 2.63 & 9.61 \\
\hline $76-41$ & 4.5 & 4.93 & 5.27 & 1.64 & 0.55 & 1.60 & 5.65 & 2.04 & 2.00 & 7.06 \\
\hline $76-103$ & 4.6 & 5.46 & 6.21 & $2.33 \star$ & $0.62 \star$ & $1.23 *$ & 6.40 & 2.46 & 1.33 & 3.88 \\
\hline $76-112$ & 4.3 & 4.91 & 5.55 & 1.79 & 0.69 & 1.75 & 5.77 & 2.11 & 1.90 & 6.26 \\
\hline $76-113$ & 4.5 & 5.50 & 6.06 & 1.59 * & $0.48 \star$ & $0.80^{\star}$ & 6.11 & 1.83 & 1.17 & 4.24 \\
\hline $76-160$ & 4.5 & 4.91 & 5.49 & $1.58 *$ & $0.65 *$ & $1.83^{*}$ & 5.65 & 1.98 & 1.85 & 5.83 \\
\hline $76-164$ & 4.2 & 5.66 & 6.62 & $2.72 \star$ & $0.57 *$ & $0.88 *$ & 6.80 & 2.88 & 0.92 & 2.81 \\
\hline A月76-13 & 4.5 & 5.04 & 6.30 & $2.67 \star$ & $0.72 *$ & $1.18 *$ & 6.38 & 2.77 & 1.20 & 3.14 \\
\hline DAH 76-2b & 4.5 & 5.26 & 6.30 & $2.50 \star$ & $0.69 *$ & $1.33 *$ & 6.40 & 2.60 & 1.34 & 3.65 \\
\hline DAH 76-3b & 4.8 & 5.50 & 6.60 & $2.60 \star$ & $0.65 *$ & $1.05 \star$ & 6.67 & 2.72 & 1.04 & 2.94 \\
\hline DAH76-5 & 4.8 & 5.04 & 5.54 & 1.58 & 0.60 & 1.62 & 5.76 & 1.97 & 1.84 & 5.72 \\
\hline DAH 76-6b & 4.8 & 5.44 & 6.22 & $2.17 \star$ & 0.69 * & $1.42 \star$ & 6.42 & 2.34 & 1.48 & 4.35 \\
\hline
\end{tabular}

*Values calculated from phi size/percent levels which were derived by extrapolation of the cumulative distribution. 
TABLE 18

SAND, SILT AND CLAY PERCENTAGES IN PORTLAND HILLS SILT, WILLAMETTE SILT, HELVETIA AND TUALATIN VALLEY

TROUTDALE EQUIVALENT SAMPLES

\begin{tabular}{|c|c|c|c|}
\hline $\begin{array}{l}\text { SAMPLE } \\
\text { NUMBER } \\
\end{array}$ & $\begin{array}{c}\text { SAND } \\
(>.062 \mathrm{~mm})\end{array}$ & $\begin{array}{c}\text { SILT } \\
(.062-.004 \mathrm{~mm})\end{array}$ & $\begin{array}{c}\text { CLAY } \\
(<.004 \mathrm{~mm}) \\
\end{array}$ \\
\hline $\begin{array}{l}\text { Portland } \\
\text { H11s S1lt } \\
75-33 \\
75-41 \\
75-45 \\
75-83 \\
76-7 \\
76-15 \\
76-17 \\
76-29 \\
76-32 \\
76-41 \\
76-103 \\
76-112 \\
76-113 \\
76-160 \\
76-164 \\
\text { AH 76-13 } \\
\text { DAH76-2b } \\
\text { DAH76-3b } \\
\text { DAH76-5 } \\
\text { DAH76-6b }\end{array}$ & $\begin{array}{r}4.2 \\
3.4 \\
4.4 \\
5.8 \\
7.9 \\
4.3 \\
11.3 \\
5.7 \\
6.0 \\
7.7 \\
2.8 \\
3.5 \\
1.6 \\
4.3 \\
4.0 \\
7.4 \\
3.5 \\
4.4 \\
4.2 \\
1.3\end{array}$ & $\begin{array}{l}72.4 \\
83.9 \\
73.0 \\
87.7 \\
83.5 \\
83.6 \\
76.4 \\
80.7 \\
85.8 \\
82.0 \\
76.9 \\
83.3 \\
79.8 \\
84.4 \\
69.0 \\
69.5 \\
75.8 \\
70.7 \\
84.0 \\
79.6\end{array}$ & $\begin{array}{r}23.4 \\
12.6 \\
22.5 \\
6.5 \\
8.7 \\
12.1 \\
12.3 \\
13.6 \\
8.2 \\
10.3 \\
20.4 \\
13.2 \\
18.6 \\
11.3 \\
27.0 \\
23.1 \\
20.7 \\
24.9 \\
11.8 \\
19.1\end{array}$ \\
\hline $\begin{array}{l}75-10 \\
75-13 \\
75-17 \\
75-39 \\
75-42 \\
75-61 a \\
75-64 b \\
75-71 \\
75-77 \\
75-81 \\
75-84 \\
75-86 \\
76-4 \\
76-6 \\
76-11 \\
76-12 \\
76-13 \\
76-16 \\
76-19 \\
76-21 \\
76-23\end{array}$ & $\begin{array}{l}4.4 \\
4.5 \\
1.4 \\
2.2 \\
5.2 \\
5.7 \\
5.7 \\
3.9 \\
5.2 \\
3.2 \\
6.6 \\
3.5 \\
6.7 \\
9.4 \\
1.4 \\
5.3 \\
6.8 \\
3.0 \\
3.6 \\
3.9 \\
3.1\end{array}$ & $\begin{array}{l}75.7 \\
77.5 \\
74.3 \\
78.5 \\
80.1 \\
86.3 \\
82.6 \\
71.9 \\
81.2 \\
56.9 \\
84.6 \\
75.0 \\
77.3 \\
80.1 \\
84.5 \\
87.5 \\
81.7 \\
70.9 \\
73.6 \\
75.0 \\
71.5\end{array}$ & $\begin{array}{r}19.9 \\
18.0 \\
24.3 \\
19.3 \\
14.7 \\
9.0 \\
13.7 \\
24.2 \\
13.6 \\
39.9 \\
8.8 \\
21.5 \\
16.0 \\
10.5 \\
14.1 \\
7.2 \\
14.5 \\
26.1 \\
22.8 \\
21.1 \\
25.4\end{array}$ \\
\hline
\end{tabular}


TABLE 18 CONTINUED

\begin{tabular}{|c|c|c|c|}
\hline $\begin{array}{l}\text { SAMPLE } \\
\text { NUMBER } \\
\end{array}$ & $\begin{array}{l}\text { SAND } \\
(>.062 \mathrm{~mm}) \\
\end{array}$ & $\begin{array}{c}\text { SILT } \\
(.062-.004 \mathrm{~mm}) \\
\end{array}$ & $\begin{array}{c}\text { CLAY } \\
(<.004 \text { mm }) \\
\end{array}$ \\
\hline $\begin{array}{l}76-30 \\
76-34 \\
76-36 \\
76-40 \\
76-46 \\
76-52 \\
76-57 \\
76-61 \\
76-64 \\
76-66 \\
76-69 \\
76-76 \\
76-83 \\
76-86 \\
76-114 \\
76-124 \\
76-191 \\
\text { AH76-8 } \\
\text { AH76-10 } \\
\text { AH76-12 }\end{array}$ & $\begin{array}{r}8.9 \\
14.2 \\
3.7 \\
3.4 \\
2.8 \\
3.2 \\
3.9 \\
9.0 \\
9.2 \\
4.8 \\
3.5 \\
3.0 \\
5.5 \\
2.4 \\
1.4 \\
6.3 \\
2.9 \\
4.4 \\
5.8 \\
2.6\end{array}$ & $\begin{array}{l}76.3 \\
62.4 \\
77.5 \\
77.1 \\
71.2 \\
74.1 \\
59.1 \\
73.8 \\
79.0 \\
83.6 \\
71.3 \\
77.7 \\
78.8 \\
73.6 \\
69.7 \\
71.7 \\
72.6 \\
73.4 \\
77.1 \\
77.3\end{array}$ & $\begin{array}{l}14.6 \\
23.4 \\
18.8 \\
19.5 \\
26.0 \\
22.7 \\
37.0 \\
17.2 \\
11.8 \\
11.4 \\
25.2 \\
19.3 \\
15.7 \\
24.0 \\
28.9 \\
22.0 \\
24.5 \\
22.2 \\
17.1 \\
20.1\end{array}$ \\
\hline $\begin{array}{r}\text { DAH 76-1a } \\
\mathrm{b} \\
\mathrm{c} \\
\mathrm{d} \\
\mathrm{e} \\
\mathrm{f} \\
\mathrm{g} \\
\text { DAH76-2a } \\
\mathrm{b} \\
\mathrm{c} \\
\mathrm{d} \\
\mathrm{e} \\
\mathrm{f} \\
\mathrm{g} \\
\text { DAH76-3a } \\
\mathrm{b} \\
\mathrm{c} \\
\mathrm{d} \\
\mathrm{e} \\
\mathrm{f} \\
\mathrm{g} \\
\text { DAH76-4a } \\
\mathrm{b} \\
\mathrm{c} \\
\mathrm{d}\end{array}$ & $\begin{array}{l}2.0 \\
3.3 \\
1.8 \\
3.7 \\
3.0 \\
2.8 \\
3.8 \\
4.1 \\
3.5 \\
4.3 \\
3.0 \\
2.9 \\
1.9 \\
1.7 \\
3.4 \\
4.4 \\
3.3 \\
3.0 \\
2.9 \\
1.6 \\
2.0 \\
0.2 \\
3.7 \\
4.1 \\
1.9\end{array}$ & $\begin{array}{l}56.2 \\
67.3 \\
70.5 \\
80.9 \\
78.7 \\
71.1 \\
74.1 \\
79.3 \\
75.8 \\
77.9 \\
73.3 \\
73.9 \\
82.6 \\
82.0 \\
80.1 \\
70.6 \\
69.3 \\
71.4 \\
78.6 \\
84.2 \\
80.2 \\
80.2 \\
76.2 \\
69.0 \\
70.1\end{array}$ & $\begin{array}{l}41.8 \\
29.4 \\
27.7 \\
15.4 \\
18.3 \\
26.1 \\
22.1 \\
16.6 \\
20.7 \\
17.8 \\
23.7 \\
23.2 \\
15.5 \\
16.3 \\
16.5 \\
24.9 \\
27.4 \\
25.6 \\
18.5 \\
14.2 \\
17.8 \\
19.6 \\
20.1 \\
26.9 \\
28.0\end{array}$ \\
\hline
\end{tabular}


TABLE 18 CONTINUED

\begin{tabular}{|c|c|c|c|}
\hline $\begin{array}{l}\text { SAMPLE } \\
\text { NUMBER } \\
\end{array}$ & $\begin{array}{c}\text { SAND } \\
(>.062 \mathrm{~mm}) \\
\end{array}$ & $\begin{array}{c}\text { SILT } \\
(.062-.004 \mathrm{~mm}) \\
\end{array}$ & $\begin{array}{c}\text { CLAY } \\
(<.004 \mathrm{~mm}) \\
\end{array}$ \\
\hline DAH76-4e & 2.2 & 73.4 & 24.4 \\
\hline $\mathrm{f}$ & 3.3 & 76.3 & 20.4 \\
\hline $\mathrm{g}$ & 4.6 & 80.3 & 15.1 \\
\hline DAH76-6a & 2.5 & 65.8 & 31.7 \\
\hline b & 1.3 & 79.5 & 19.3 \\
\hline c & 1.9 & 74.3 & 23.8 \\
\hline d & 2.7 & 66.5 & 30.8 \\
\hline e & 2.2 & 83.3 & 14.4 \\
\hline $\mathrm{E}$ & 1.7 & 84.8 & 13.5 \\
\hline $\mathrm{g}$ & 1.8 & 87.3 & 10.9 \\
\hline h & 0.9 & 79.9 & 19.2 \\
\hline 1 & 1.3 & 79.2 & 19.6 \\
\hline$j$ & 1.4 & 71.0 & 27.5 \\
\hline k & 1.6 & 73.5 & 24.9 \\
\hline 1 & 0.6 & 74.1 & 25.3 \\
\hline m & 1.6 & 67.7 & 30.7 \\
\hline 0 & 2.1 & 69.9 & 28.0 \\
\hline $\mathrm{p}$ & 2.3 & 83.2 & 14.5 \\
\hline $76-126$ & 3.3 & 64.8 & 31.9 \\
\hline $76-127$ & 6.7 & 64.1 & 29.2 \\
\hline $76-128$ & 2.0 & 69.2 & 28.8 \\
\hline $76-129$ & 2.2 & 71.6 & 26.2 \\
\hline $76-134$ & 1.9 & 75.1 & 23.0 \\
\hline $76-130$ & 0.8 & 74.2 & 25.0 \\
\hline $76-131$ & 1.7 & 68.1 & 30.2 \\
\hline $76-132$ & 1.3 & 72.1 & 26.6 \\
\hline $76-133$ & 1.9 & 65.0 & 38.1 \\
\hline WS76-I & 0.8 & 70.3 & 28.9 \\
\hline WS76-2 & 0.4 & 69.0 & 30.6 \\
\hline WS 76-3 & 1.6 & 66.6 & 31.8 \\
\hline WS $76-4$ & 1.0 & 72.4 & 26.6 \\
\hline WS76-5 & 0.9 & 73.2 & 25.9 \\
\hline HEL 75-90 & 10.9 & 65.8 & 23.2 \\
\hline HEL 75-91 & 6.2 & 60.5 & 33.3 \\
\hline HEL 75-93 & 4.2 & 55.7 & 40.1 \\
\hline HEL 75-94 & 7.4 & 60.0 & 33.6 \\
\hline HEL 75-95 & 13.2 & 48.8 & 38.0 \\
\hline HEL 76-110 & 3.5 & 52.4 & 44.1 \\
\hline HEL 76-121 & 0.7 & 57.5 & 41.8 \\
\hline HEL 76-98 & 7.0 & 68.5 & 24.6 \\
\hline TT75-66 & 45.9 & 17.7 & 12.7 \\
\hline TT76-181 & 31.0 & 55.5 & 13.5 \\
\hline TT76-196 & 10.6 & 87.7 & 7.7 \\
\hline TT76-148 & 1.7 & 61.8 & 37.5 \\
\hline
\end{tabular}




\section{APPENDIX C}

TABLE 19

HEAVY MINERALS IN TUALATIN VALLEY TROUTDALE EQUIVALENT, WILLAMETTE SILT AND HELVETIA SAMPLES

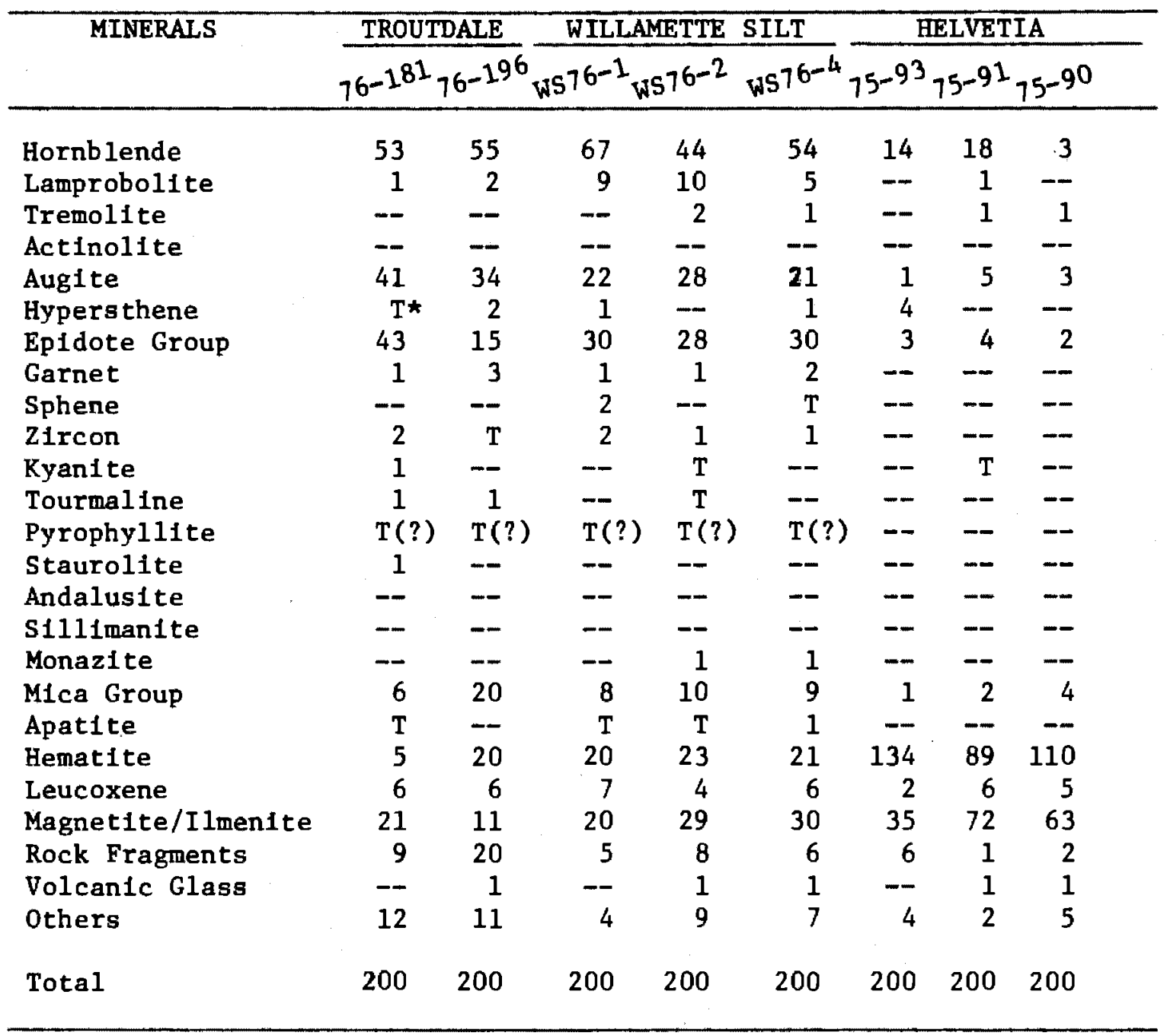

*Minerals were noted but did not come under the cross hairs during counting traverses. 
APPENDIX D

LOCATION AND DESCRIPTION OF SAMPLES

FROM OUTLYING AREAS

\begin{tabular}{|c|c|c|}
\hline $\begin{array}{l}\text { SAMPLE } \\
\text { NUMBER } \\
\end{array}$ & LOCATION & DESCRIPTION \\
\hline $76-181$ & $\begin{array}{l}\text { Beaverton } 7 \frac{1}{2}{ }^{\prime} \text { Quadrangle, } \\
\text { SW } \frac{1}{4} N W \frac{1}{2} \text {, sec. } 19 \text {, T.1S., } \\
\text { R.1W. }\end{array}$ & $\begin{array}{l}\text { Construction cut along Elwert } \\
\text { Rd., Elev. } 160 \mathrm{ft} \text {, Troutdale, } \\
\text { bedded sandstone \& mudstone. }\end{array}$ \\
\hline $76-185$ & $\begin{array}{l}\text { Newberg } 7 \frac{1}{2} \text { ' Quadrangle, } \\
E^{\frac{1}{4}} \text {, sec. } 26, \text { T.2S., R.2 } \\
\text { W. }\end{array}$ & $\begin{array}{l}\text { Road cut along Edy Rd., Elev. } \\
420 \mathrm{ft} \text {, massive Portland } \\
\text { Hills Silt. }\end{array}$ \\
\hline $76-187$ & $\begin{array}{l}\text { Bridal Vetl } 15^{\prime} \text { Quad- } \\
\text { rangle, CNE⿺ sec. } 31 \text {, } \\
\text { T.1S., R.5E. }\end{array}$ & $\begin{array}{l}\text { Road cut along Larch Mtn. Rd., } \\
\text { Elev. } 950 \mathrm{ft} \text {, Massive Port- } \\
\text { land Hills Silt. }\end{array}$ \\
\hline $76-188$ & 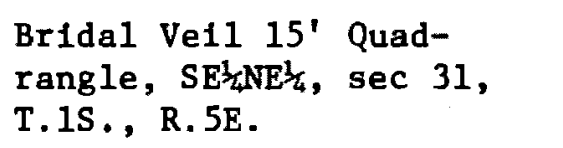 & $\begin{array}{l}\text { Road cut along Larch Mtn. Rd., } \\
\text { Elev. } 1150 \mathrm{ft} \text {, massive Port- } \\
\text { land Hills Silt. }\end{array}$ \\
\hline $76-189$ & $\begin{array}{l}\text { Bridal Ve1l } 15^{\prime} \text { Quad- } \\
\text { rangle, SE } \frac{1}{4} \mathrm{SE}^{\frac{1}{4}} \text {, sec. } 31 \text {, } \\
\text { T.1S., R.5E. }\end{array}$ & $\begin{array}{l}\text { Road cut along Larch Mtn. Rd. } \\
\text { Elev. } 1200 \mathrm{ft} \text {, massive Port- } \\
\text { land Hills Silt. }\end{array}$ \\
\hline $76-190$ & $\begin{array}{l}\text { Dixie Mtn. } 7 \frac{1}{2} \text { ' Quadrangle, } \\
\text { NE } \frac{1}{4} \mathrm{SW}^{\frac{1}{4}} \text {, sec. } 35, \text { T.2N., } \\
\text { R.1W. }\end{array}$ & $\begin{array}{l}\text { Road cut along Rocky Point } \\
\text { Rd., Elev. } 1120 \mathrm{ft} \text {, massive } \\
\text { Portland Hills Silt. }\end{array}$ \\
\hline $76-193$ & 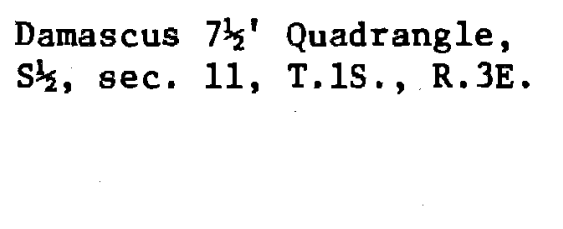 & $\begin{array}{l}\text { Construction cut behind Fred- } \\
\text { meyer Shopping Center, Elev. } \\
400 \mathrm{ft} \text {, Portland Hills S1lt } \\
\text { with secondary iron oxide } \\
\text { laminations }\end{array}$ \\
\hline $76-194$ & $\begin{array}{l}\text { Damascus } 7 \frac{1}{2} \text { ' Quadrangle, } \\
\text { NW' } \frac{1}{2} \mathrm{NE}^{\frac{1}{4}} \text {, sec. } 26, \text { T.1S., } \\
\text { R. } 3 \mathrm{E} \text {. }\end{array}$ & $\begin{array}{l}\text { Road cut along Anderson Rd., } \\
\text { Elev. } 470 \mathrm{ft} \text {, massive Port- } \\
\text { land Hills Silt. }\end{array}$ \\
\hline $76-196$ & $\begin{array}{l}\text { Scholls } 7 \frac{1}{2} \text { ' Quadrangle, } \\
\text { NW/2SW } \\
\text { R. } 2 \text { W. }\end{array}$ & $\begin{array}{l}\text { Drill hole, } 48-49 \mathrm{ft} \text { below } \\
\text { the surface elev. (150 ft) } \\
\text { Sample provided by } \mathrm{CH}_{2} \mathrm{M} \mathrm{H} \text { Hil. } \\
\text { Laminated Troutdale silt. }\end{array}$ \\
\hline
\end{tabular}




\section{APPENDIX E}

\section{LOCATION OF PEEL AND ORIENTED}

SLAB SITES

\begin{tabular}{|c|c|c|}
\hline $\begin{array}{c}\text { SITE } \\
\text { NUMBER }\end{array}$ & LOCATION & DESCRIPTION \\
\hline$\# 1$ & 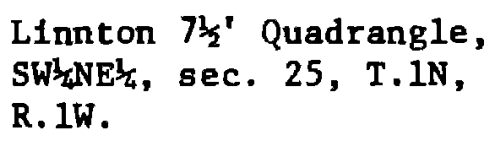 & $\begin{array}{l}\text { Road cut along Thompson Rd., } \\
\text { Elev. } 945 \mathrm{ft} \text {, samples at } 7-8 \\
\text { ft depth. }\end{array}$ \\
\hline |⿰ 2 & $\begin{array}{l}\text { Linnton } 7 \frac{1}{2} \text { ' Quadrangle, } \\
\text { SW/ SE } \frac{1}{4} \text {, sec. } 23 \text {, T.1N, } \\
\text { R. } 1 \text { W. }\end{array}$ & $\begin{array}{l}\text { Road cut along Skyline Blvd., } \\
\text { Elev. } 1100 \mathrm{ft} \text {, samples at } \\
36-37 \mathrm{ft} \text { depth. }\end{array}$ \\
\hline$\# 3$ & $\begin{array}{l}\text { Linnton } 7 \frac{1}{2} \text { ' Quadrangle, } \\
\text { NW' } \frac{1}{4} W^{\frac{1}{4}} \text {, sec } 23, \text { T.1N, } \\
\text { R. } 1 W \text {. }\end{array}$ & $\begin{array}{l}\text { Road cut along Skyline B1vd., } \\
\text { Elev. } 1100 \mathrm{ft} \text {, samples at } 6-7 \\
\text { depth. }\end{array}$ \\
\hline
\end{tabular}




\section{APPENDIX F \\ DESCRIPTION OF STRATIGRAPHIC SECTIONS}

The stratigraphic sequence and 11thology of the Portland Hills Silt is described in detall, in the following princlpal sections.

\section{DAH76-1 (F1gure 31)}

Section DAH76-1 is discussed on page 86. The boring site is a cultivated orchard, sec. 50, T.1N., R.1W., which explains the absence of a distinct A soll horizon.

\section{DAH76-2 (F1gure 32)}

This boring is located on a partially wooded site adjacent NW Springuille Rd., sec. 51, T.1N., R.1W. The section reveals a typical soll profile developed on Portland Hills Silt, with a mottled and graylsh-streaked B horizon extending to approximately $1.5 \mathrm{~m}(4.5 \mathrm{ft})$. No contacts or unconformlties are apparent to $4.7 \mathrm{~m}(15.5 \mathrm{ft})$.

\section{DAH76-3 (F1gure 33)}

Boring DAH76-3 is situated in a cultivated fleld, on a west facIng spur, near the crest of the Tualatin Mountalns sec. 15, T.1N., R. 1W. It is simflar to DAH76-2, in that, no lithologic discontinuities are present.

DAH76-4 (F1gure 34)

The location of this section is a dirt fire road on an east 
sloping ridge crest, sec. 14, T.1N., R.1W. Most of the surface weathering profile, an estimated one meter, is missing from the top of the section because of road grading. A 2 m deep auger hole (DAH76-5) bored about one kilometer northwest, atop the same ridge, confirmed the presence of this profile.

DAH76-4 displays a prominent paleosol at a depth between 2 and $3.5 \mathrm{~m}$. The buried soll 1 s characterized by a dark reddish-brown oxidized color, strong mottling, numerous shot and high relative clay and organic carbon content.

\section{DAH76-6 (F1gure 35)}

Th1s is the deepest of the s1x stratigraphic sections. It 1s situated at the very sumit of the hills and extends to a maximum depth of $13.7 \mathrm{~m}(45 \mathrm{ft})$. Four separate and distinct soll profiles are present in DAH76-6 and are designated $s_{1}, s_{2}, s_{3}$ and $s_{4}$. The surface prof1le, $S_{1}$, is developed beneath a natural grass cover. It displays the gray, leached and root filled foints, which are characteristic of the surface weathering profile, and many paleosols in the Portland Hills S11t. The moderate brown color of $S_{2}$ is unlike that of most of the other burled solls, which are redder in tone. Mottling and high clay, shot and organic carbon content, however, st1ll 1mply a pedologic or1gin. Profile $S_{2}$ is developed upon the thickest of the silt units, a layer some $6 \mathrm{~m}(20 \mathrm{ft})$ thick. By contrast, $s_{3}$ is developed upon a thin, $2 \mathrm{~m}$ thick layer and may overlap the oldest unit, and $1 \mathrm{t}^{\prime} \mathrm{s}$ paleosol, $\mathrm{s}_{4}$.

Skyline School Section (F1gure 36)

Changes in 11thology and structure in this road cut indicate the 
presence of three burled soll horizons. These are tentatively correlated with those described in DAH76-6.

The texture of the Portland H11ls Silt is generally finer gralned In the Skyline School section (average clay content, 28 percent) than In previous sections (1.e., DAH76-6, average clay content, 20 percent). Th1s may, in part, be due to more complete weathering of the relatively thin silt units in this area. An abundance of concretionary shot corroborates this notion. However, decreasing thickness of the silt suggests a location near the margin of deposition. If this is the case, the grain size may be largely the result of primary deposition. 
FIGURE 31. Section DAH76-1

\section{DESCRIPTION}

MILIAMETTE SILT

DRY, FIRM, YELLOWISH-BROWN

(IOYR 5/2) MICACEOUS SLIGHTLY

SANDY SILT. NO SHOT.

MOIST, MOD. STIFF, DARK YELLOWBROWN (LOYR 4/4) UNIFORM MICACEOUS CLAYEY SILT. NO SHOT.

MOIST, MOD. STIFF, MOD. YELLOWISHBROWN (IOYR 5/4) MICACEOUS CLAYEY SILT. MOTTLED AND STREAKED (?) WITH LT. YELLOWISH-BROWN AND RUST RED. NO SHOT. NEARLY UNIFORM COLOR BELOW 4 FEET.

NET, FIRM, NEARLY UNIFORM MICACEOUS SILT. RARE 1-2m BLACK SHOT.

\section{PORTLAND HILLS SILT}

WET, MOD, STIFF, MOD, YELLOWISH BROWN (IOYR 5/4.5) MICACEOUS SILT. STREAKED AND MOTTLED (?). SCATTERED 1-4mm BLACK SHOT. STREAKS MORE PRONOLNCED BELOW 12 FEET.

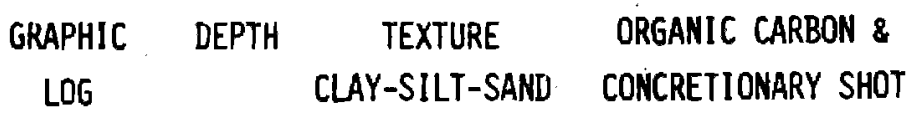

EL
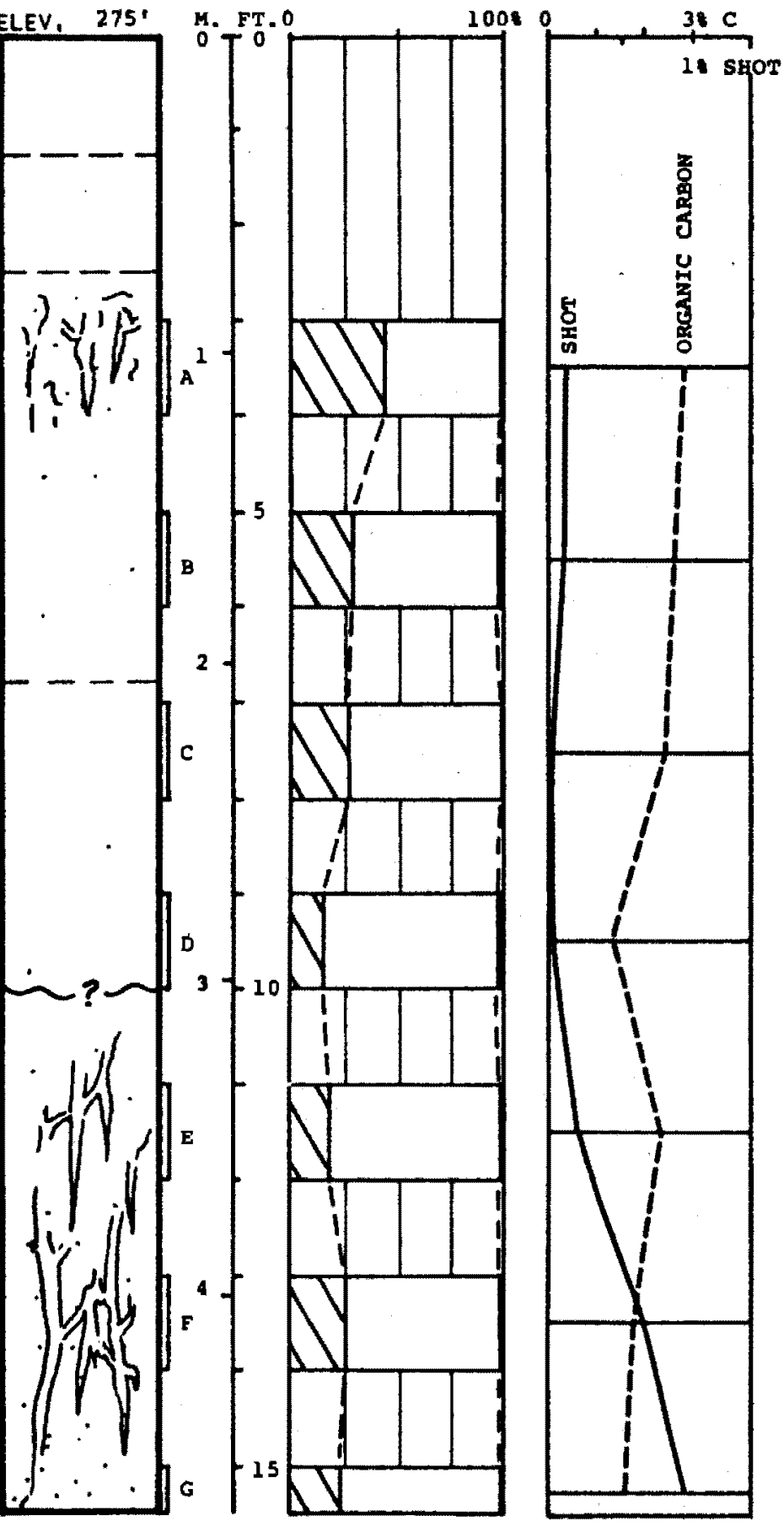
FIGURE 32. Section DAH76-2

DESCRIPTION

PORTLAND HILLS SILT HUMUS

DRY, SLIGHTLY STIFF, MOD. YELLOWISH-BROWN (1OYR 3.5/4) MICACEOUS

CLAYEY SILT. FEW SHOT.

MOIST, FIRM, LT, REDDISH-BROWN

(1OYR 4/6) MICACEOUS CLAYEY SILT.

VERY MOTTLED AND STREAKED(?) WITY

PALE YELLOWISH-BROWN (1OYR 6/2) AND

IT. RUST-BROWN (5YR 5/6). DECREAS ING SHOT.

MOIST TO WET, MOD. STIFF AND

PLASTIC, DARK YELLOWISH-BROWN (1OYR 4/4) MICACEOUS SILT. UNIFORM COLOR AVTD TEXTURE, RARE SHOT.

\section{GRAPHIC DEPTH TEXTURE ORGANIC CARBON \& LOG \\ CLAY-SILT-SAND CONCRETIONARY SHOT}
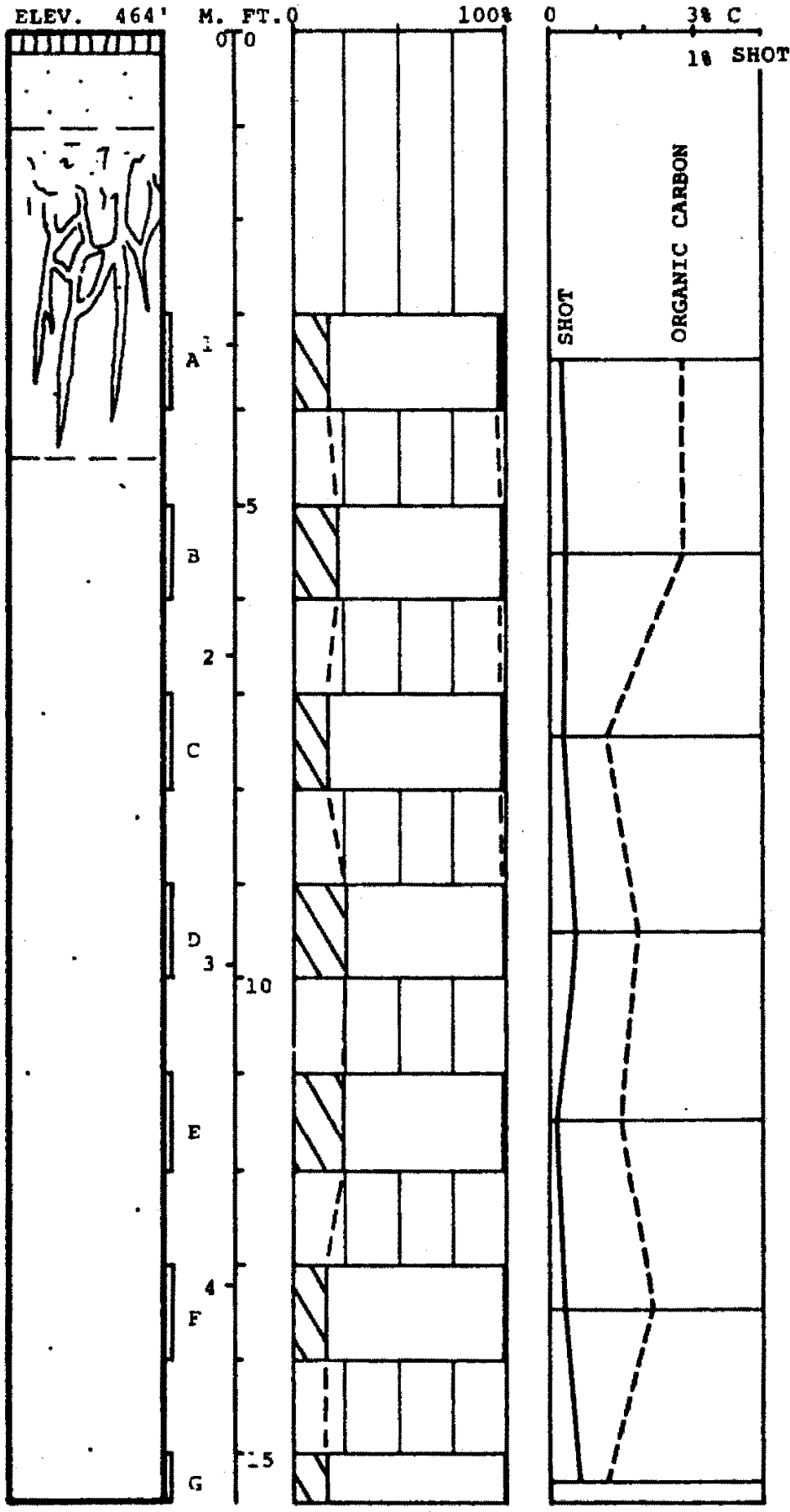
FIGURE 33. Section DAH76-3

PORTLAND HILLS SILT

DRY, MOD. STIFF, GRAYISH-ORANGE MICACEOUS SILT. VERY SLIGHTLY MOTTLED (?). FEW SHOT.

DRY, FRIABLE, DARK YELLOWISHBROFN (10YR 4/4) MICACEOUS SILT. SLIGHTLY MOTTLED AND STREAKED (?). SCATTERED 2-4MM BLACK SHOT.

BECOMINE MOIST, UNIFORM MICACEOUS CLAYEY SILT.
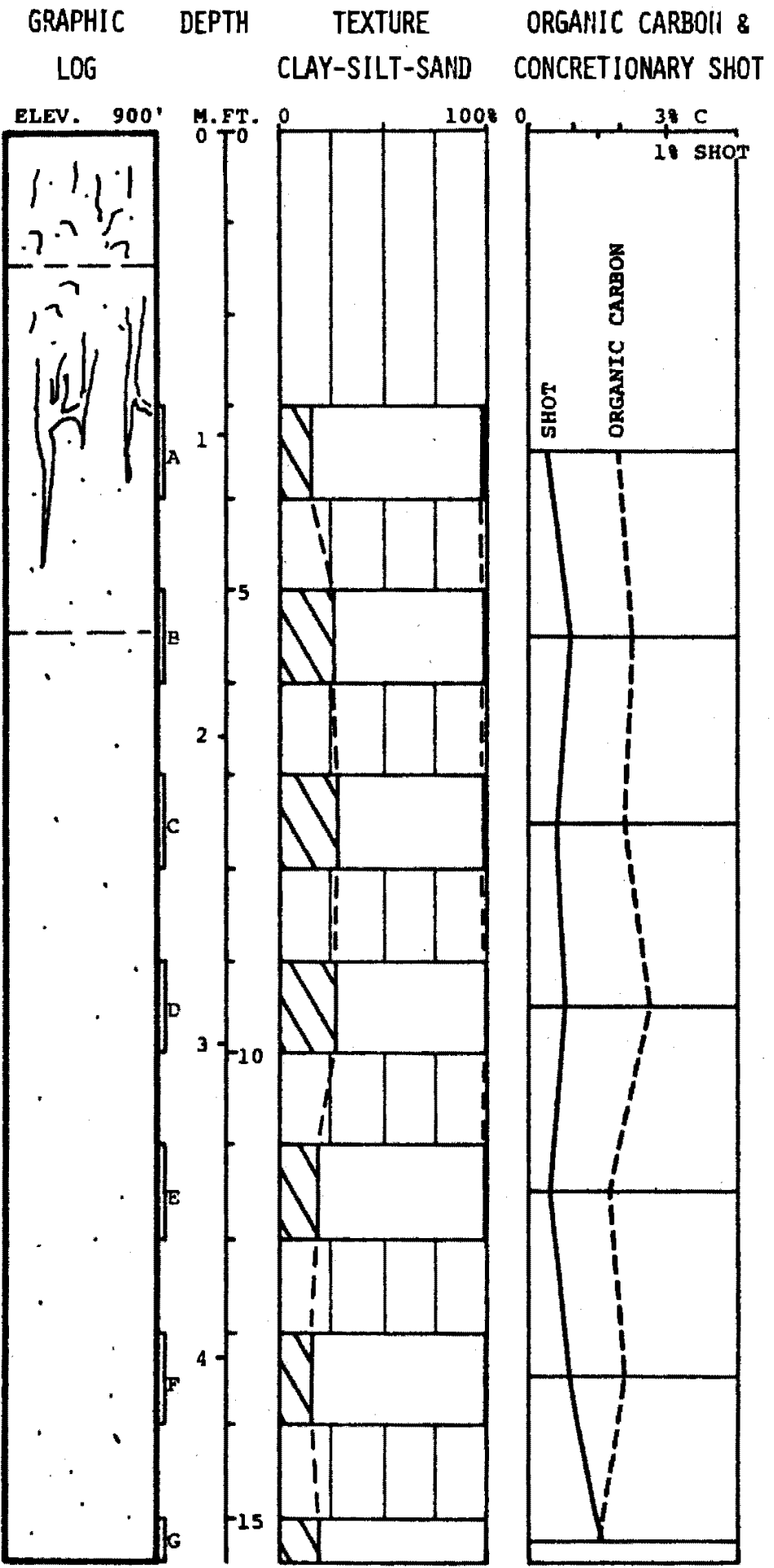
FIGURE 34. Section DAH76-4

DESCRIPTION

PORTLAND HILLS SILT

HOIST, FRIABLE, LT. REDDISH-BROWN MICACEOUS SILT. SLIGHTLY MOTTLED WITH LT. BROWN AND RUST-ORANGE.

WET, FIRM, MOD. YELLOWISH-BROWN (LOYR 5/4) MICACEOUS SILT. NEARLY UNIFORM COLOR AND TEXTURE.

BECOMING MOTTLED WITH MOD. RUSTORANGE. SOME BLACK-BRONN SHOT.

MOIST TO VERY MOIST, STIFF TO

FRIAELE, OXIDIZED, DARK REDDISHGROWN (6YR 4/6) MICACEOUS CLAYEY SILT. STRONGLY MOTTLED WITH RUSTORANGE AND BLACK BROWN SHOT. MOD. TO WEAKLY MOTTLED BELOW B'.

BECOMES MOIST, MOD, STIFF, MOD. YELLOWISH-BROWN (IOYR 4/4) MICACEOUS SILT. UNIFORM COLOR AND TEXTURE.

BECOMES SLICHTLY MOIST, FRIABLE, MOD. YELLOWISH-BROWN (1OYR 5/5)" MICACEOUS SILT.

\author{
GRAPHIC DEPTH TEXTURE \\ LOG \\ CLAY-SILT-SAHD \\ ORGAIIIC CARBON \& \\ COMCRETIONARY SHOT
}

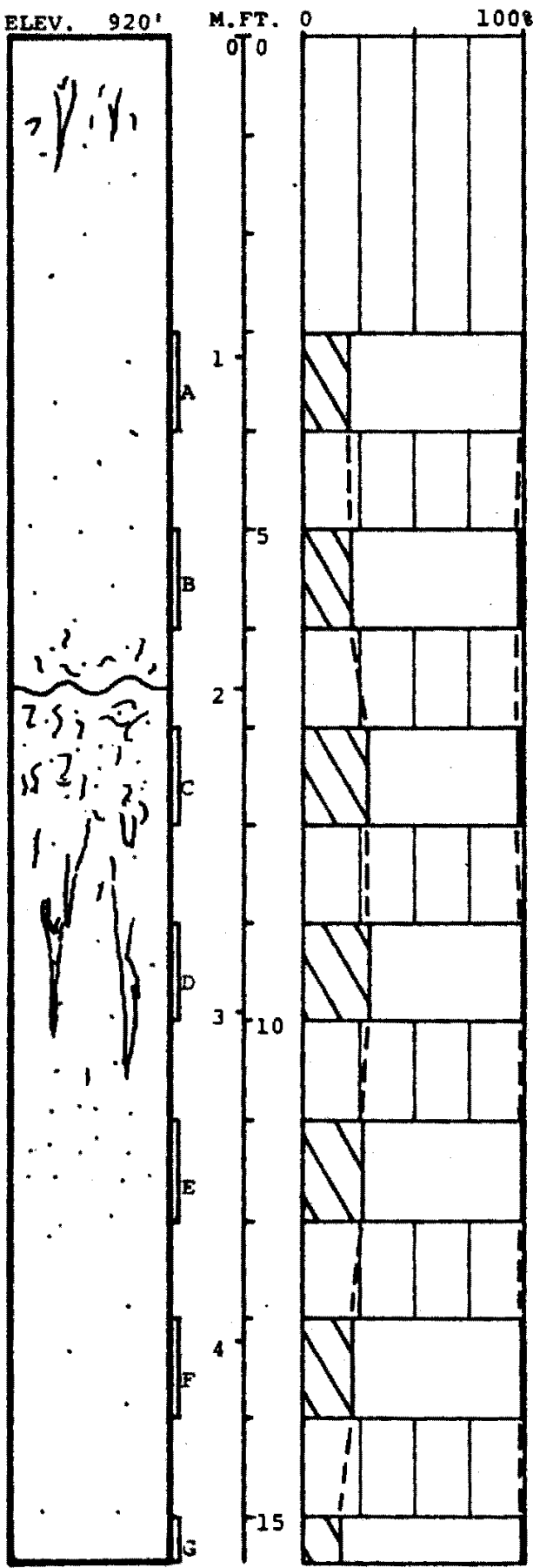


FIGURE 35. Section DAH76-6

DESCRIPTION

GRAPHIC DEPTH

TEXTURE ORGANIC CARBON \&

LOG CLAY-SILT-SAND CONCRETIONARY SHOT

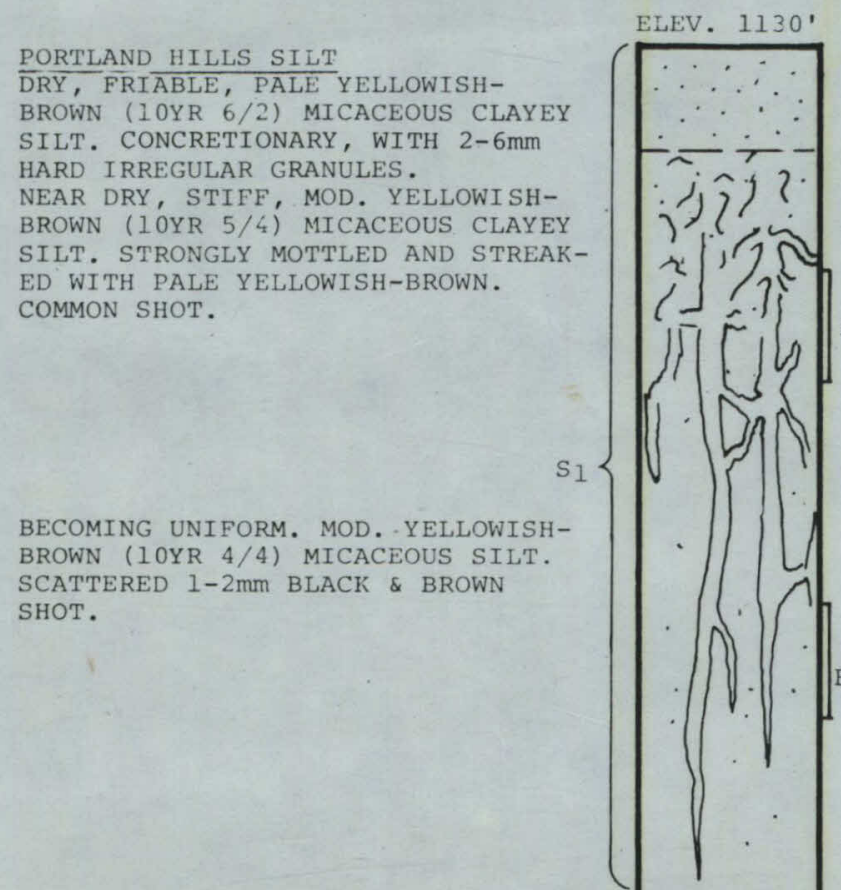

MOIST, FIRM, NEAR UNIFORM MOD.
YELLOWISH-BROWN (10YR 4//4) MIC ACEOUS SILT. SCATTERED 2-3mm SHOT.

MOIST, VERY STIFF, MOD. BROWN \&
MOD. YELOWISH-BRON MICACEOS
CLAYEY SILT. MOTTLED WITH BROWN.

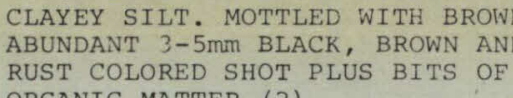
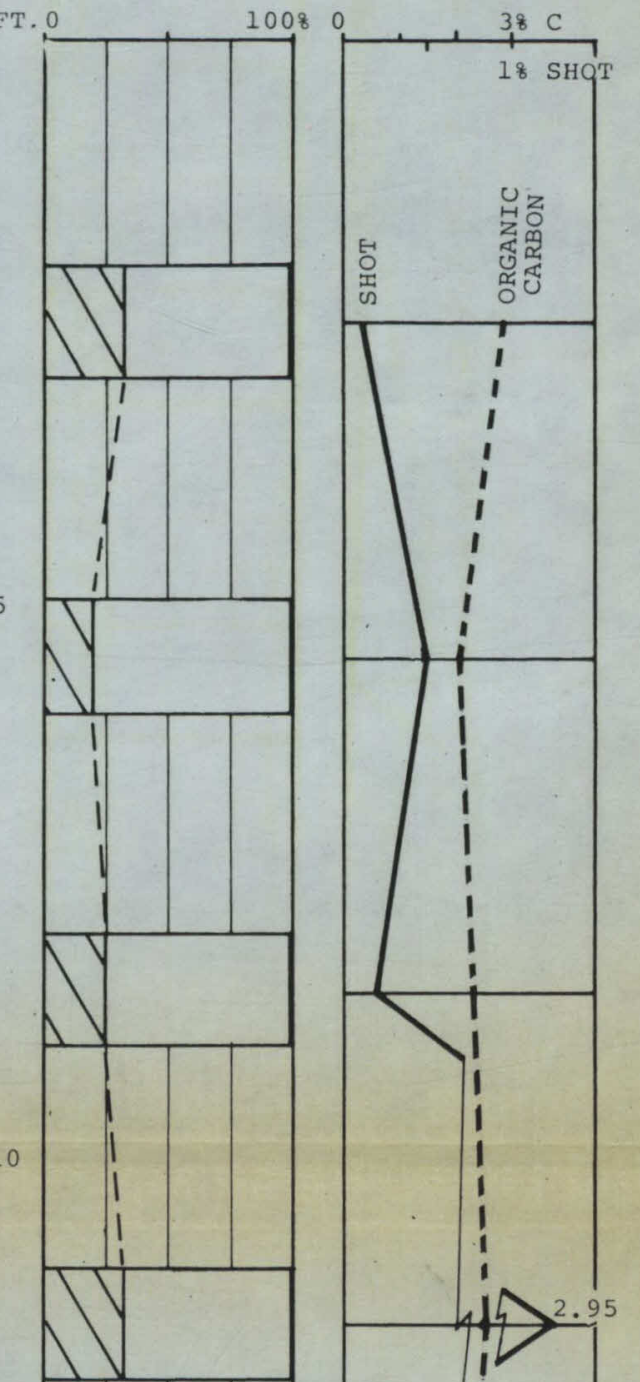

MOIST, FRTABLE (LOAMY), MOD. YEL-
LOWISH-BROWN (1OYR $/ 4$ ) MICACEOUS WOATEMOTTLING.: RARE SHOT.

MOIST, MOD. STIFF, DARKER MOD.
YELLOWISH-BROWN. SCATTERED 2-4mm SHOT, WITH A FEW $5-6 \mathrm{~mm}$.
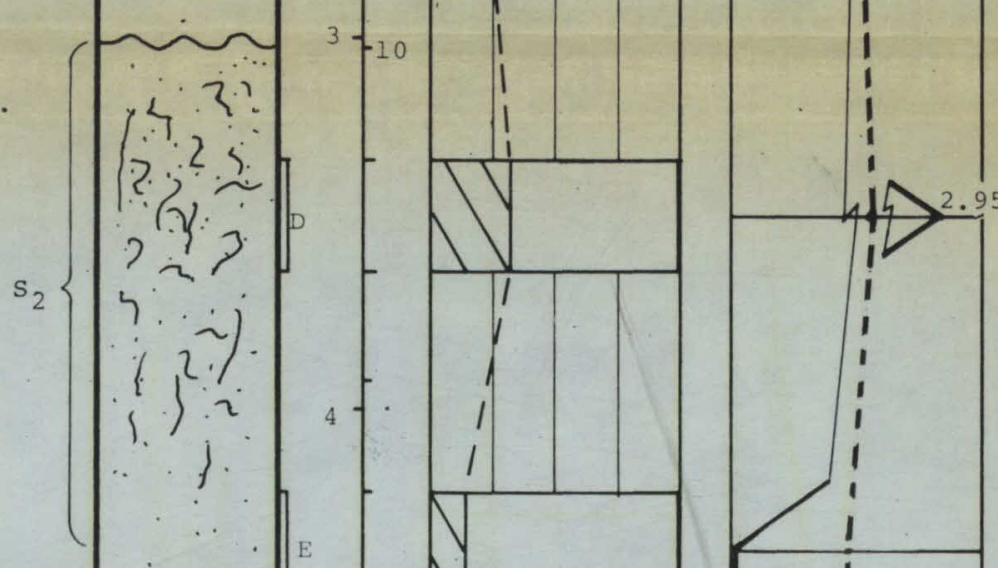

$\begin{array}{ll} & \text { MOIST, STIFF, MOD. YELLOWISH- } \\ \text { MICACEOUS CLAYEY }\end{array}$

VERY MOIST, STICF, REDDISH-BROWN STRONGLY MOTTLED WITH RUST-ORANGE.

MOIST, MOD, STIF, REDDISH-LT,
BROWN MICACEOUS CLAYEY SILT. MOTTLED AND STREAKED WITH LI,
ISH BROWN AND RUST-ORANGE

BECOMING MORE UNIFORM, LT. YEL-
LOWISH-BROWN (5YR 5/5) TO $351 / 2$.

VERY MOIST, MOD. STIFF, DARK YEL-
LOWISH-BROWN $\left(10 Y \mathrm{YR}^{2}\right.$ 5/2) MICACEOUS COMMON SHOT:
WETTER AND DARKER $36-3 \varepsilon^{\prime}$.

MOIST, STTFF, REDDISH-MOD
BROWN (TYR $5 / 4$ MICACEOIS CLAYEY SILT. MOD. MOTTLED WITH
LT. BROWN AND RUST-ORANGE. MOIST, VERY STIFF, SLIGHTLY MOTGRADES RAPIDLY INTO LIGHTER (1OYR 4.5/4) UNIFORM MICACEOUS SILT. RARE SHOT.

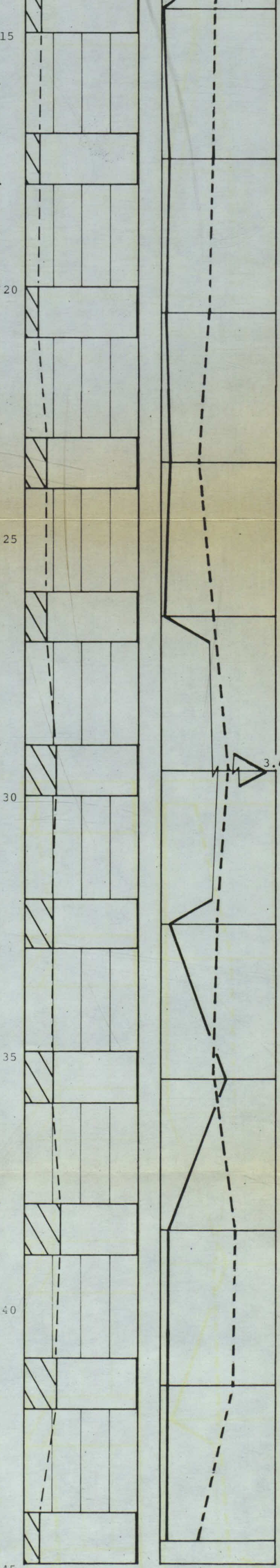

